The Geological Society of America

Special Paper 511

2015

\title{
Environmental consequences of Ontong Java Plateau and Kerguelen Plateau volcanism
}

\author{
Elisabetta Erba \\ Department of Earth Sciences, Università degli Studi di Milano, 20133 Milan, Italy \\ Robert A. Duncan \\ College of Earth, Ocean, and Atmospheric Sciences, Oregon State University, Corvallis, Oregon 97331, USA, and \\ Department of Geology \& Geophysics, King Saud University, Riyadh, KSA \\ Cinzia Bottini \\ Daniele Tiraboschi \\ Department of Earth Sciences, Università degli Studi di Milano, 20133 Milan, Italy \\ Helmut Weissert \\ Department of Earth Sciences, ETH Zurich, CH-8092 Zurich, Switzerland \\ Hugh C. Jenkyns \\ Department of Earth Sciences, University of Oxford, South Parks Road, Oxford OX1 3AN, UK \\ Alberto Malinverno \\ Lamont-Doherty Earth Observatory, Columbia University, 61 Route 9W, Palisades, New York 10964, USA
}

\begin{abstract}
The mid-Cretaceous was marked by emplacement of large igneous provinces (LIPs) that formed gigantic oceanic plateaus, affecting ecosystems on a global scale, with biota forced to face excess $\mathrm{CO}_{2}$ resulting in climate and ocean perturbations. Volcanic phases of the Ontong Java Plateau (OJP) and the southern Kerguelen Plateau (SKP) are radiometrically dated and correlate with paleoenvironmental changes, suggesting causal links between LIPs and ecosystem responses. Aptian biocalcification crises and recoveries are broadly coeval with $\mathrm{C}, \mathrm{Pb}$, and $\mathrm{Os}$ isotopic anomalies, trace metal influxes, global anoxia, and climate changes. Early Aptian greenhouse or supergreenhouse conditions were followed by prolonged cooling during the late Aptian, when OJP and SKP developed, respectively. Massive volcanism occurring at equatorial versus high paleolatitudes and submarine versus subaerial settings triggered very different climate responses but similar disruptions in the marine carbonate system. Excess $\mathrm{CO}_{2}$ arguably induced episodic ocean acidification that was detrimental to
\end{abstract}

Erba, E., Duncan, R.A., Bottini, C., Tiraboschi, D., Weissert, H., Jenkyns, H.C., and Malinverno, A., 2015, Environmental consequences of Ontong Java Plateau and Kerguelen Plateau volcanism, in Neal, C.R., Sager, W.W, Sano, T., and Erba, E., eds., The Origin, Evolution, and Environmental Impact of Oceanic Large Igneous Provinces: Geological Society of America Special Paper 511, p. 271-303, doi:10.1130/2015.2511(15). For permission to copy, contact editing@ geosociety. org. (c) 2015 The Geological Society of America. All rights reserved.

Gold Open Access: This chapter is published under the terms of the CC-BY license and is available open access on www.gsapubs.org. 
marine calcifiers, regardless of hot or cool conditions. Global anoxia was reached only under extreme warming, whereas cold conditions kept the oceans well oxygenated even at times of intensified fertility. The environmental disruptions attributed to the OJP did not trigger a mass extinction: rock-forming nannoconids and benthic communities underwent a significant decline during Oceanic Anoxic Event (OAE) 1a, but recovered when paroxysmal volcanism finished. Extinction of many planktonic foraminiferal and nannoplankton taxa, including most nannoconids, and most aragonitic rudists in latest Aptian time was likely triggered by severe ocean acidification. Upgraded dating of paleoceanographic events, improved radiometric ages of the OJP and SKP, and time-scale revision are needed to substantiate the links between magmatism and paleoenvironmental perturbations.

\section{INTRODUCTION}

The construction of large igneous provinces (LIPs) (Coffin and Eldholm, 1991, 1994) has the potential to significantly affect environmental conditions and oceanographic and atmospheric processes on the Earth's surface. Subaerial and/or submarine multiple eruptions of gigantic magmatic flows may alter the ocean-atmosphere system by introducing gases and particulates, potentially fostering warmer or cooler climates and perturbing the structure and chemistry of the oceans. Environmental consequences of LIPs were reviewed and discussed by Wignall (2001, 2005), Saunders (2005), and Neal et al. (2008). After two decades of studies dedicated to quantification of changes in climatic conditions, oceanic chemistry and fertility, and biotic responses, we can delineate the interactions between major igneous events and ecosystem dynamics.
Particular efforts have been applied to understanding biosphere reactions and adaptations to mid-Cretaceous LIPs since this time interval is characterized by massive volcanism of gigantic submarine plateaus (Larson, 1991a, 1991b), including the Ontong Java Plateau (OJP) (early Aptian), the Kerguelen Plateau (late Aptian-early Albian), and the Caribbean Plateau (Cenomanian-Santonian) (e.g., Leckie et al., 2002). The environmental perturbations associated with the greater Ontong Java event (GOJE; Ontong Java, Manihiki, and Hikurangi Plateaus; Taylor, 2006, Chandler et al., 2012; Fig. 1) include global oceanic anoxia, major warming, crises in populations of many calcifying marine organisms, biotic evolutionary changes, isotopic anomalies, and changes in ocean chemistry. The GOJE played either a direct or indirect role in affecting the ocean-atmosphere system, probably causing different responses and reactions in different parts of the global ocean during the late Barremian through Aptian time.

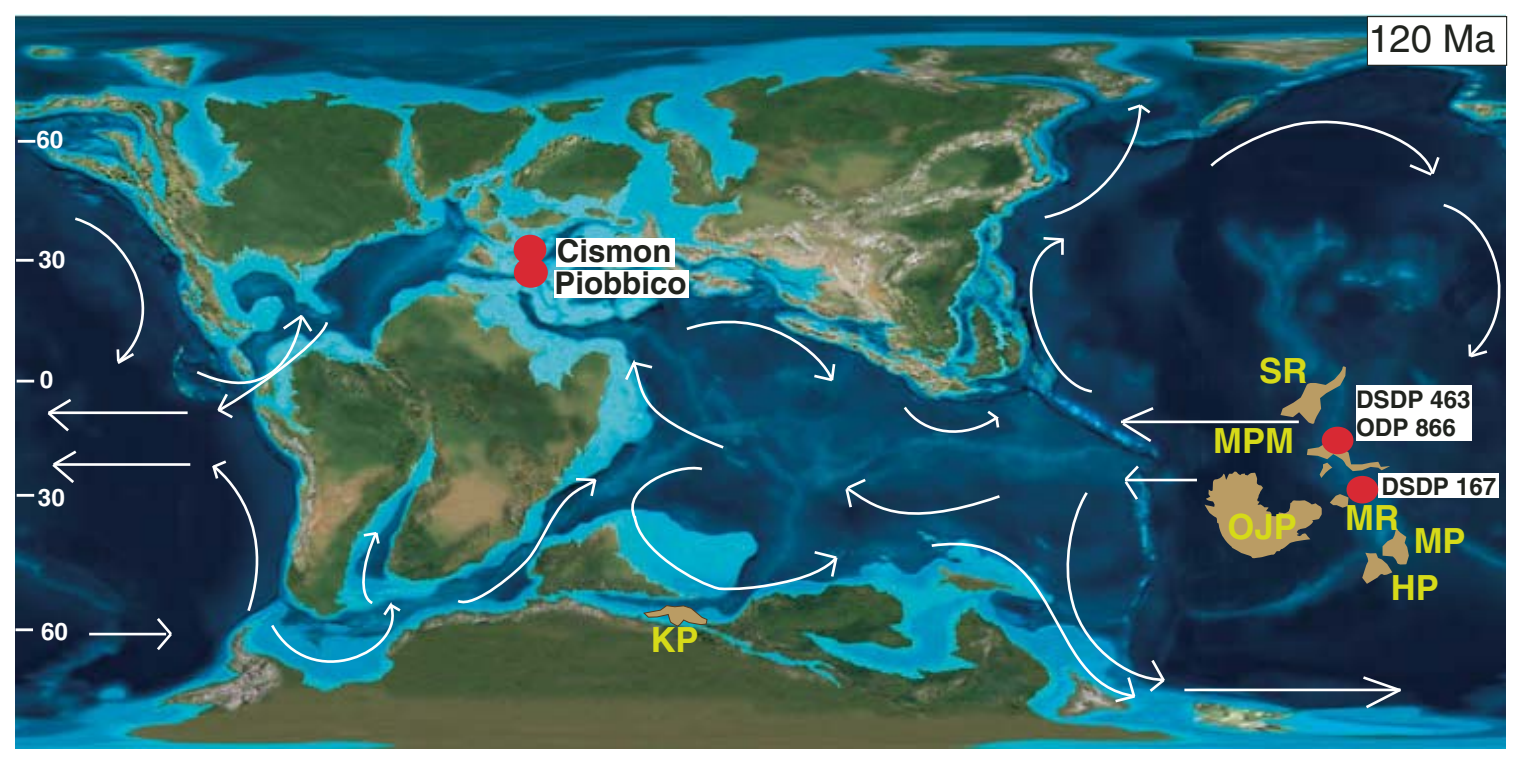

Figure 1. Location map of studied sites at $120 \mathrm{Ma}$ (modified after Larson and Erba, 1999, and http://www2.nau.edu/rcb7/ globaltext2.html). Ocean currents modified from Hay (2009). OJP—Ontong Java Plateau; KP_Kerguelen Plateau; SRShatsky Rise; MPM-Mid-Pacific Mountains; MR-Magellan Rise; MP-Manihiki Plateau; HP-Hikurangi Plateau; DSDP_Deep Sea Drilling Project; ODP_Ocean Drilling Program. Cismon and Piobbico refer to locations of boreholes from which core was used in this study. 
Perhaps the most spectacular, and most studied, environmental change is regionally extensive oxygen depletion in bottom waters and/or within an expanded oxygen-minimum zone, promoting burial of large amounts of marine organic matter. This episode is called Oceanic Anoxic Event (OAE) 1a, and possibly represents the climax and/or threshold combination of complex paleoenvironmental changes during the early Aptian. Table 1 summarizes available data for the OAE 1a time interval analyzed in various oceans and sedimentary basins.

In hemipelagic and pelagic successions, the upper-lower Aptian is represented by black shales, with locally intercalated limestones, marlstones, and/or radiolarian-rich layers. The Selli Level in the Umbria-Marche Basin (Coccioni et al., 1987, 1989) is the lithostratigraphic unit established to best typify OAE 1a. Selli Level equivalents have been described in other sedimentary basins where lithological characteristics are slightly to moderately different (e.g., Bersezio, 1993; Menegatti et al., 1998; Larson and Erba, 1999; Luciani et al., 2001, 2006; Bellanca et al., 2002). Coeval and lithologically similar intervals are the Goguel Level in southeastern France (Bréhéret, 1997), and the Fischschiefer in the Lower Saxony Basin (Kemper and Zimmerle, 1978; Gaida et al., 1981; Mutterlose, 1992).

Aptian carbonate platforms are punctuated by episodic demise and major changes in benthic communities (Föllmi et al., 1994; Vahrenkamp, 1996, 2010; Grötsch et al., 1998; Weissert et al., 1998; Jenkyns and Wilson, 1999; Steuber, 2002; Wissler et al., 2003; Immenhauser et al., 2004, 2005; Burla et al., 2008; Föllmi and Gainon, 2008; Föllmi, 2008, 2012; Huck et al., 2010, 2012; Rameil et al., 2010; Masse and Fenerci-Masse, 2011; Graziano, 2013). As discussed by Yamamoto et al. (2013), early Aptian shallow-water carbonates show different facies changes according to their paleogeographic position: the northern Tethyan platforms were episodically drowned, while in the central to southern NeoTethys margins carbonate deposition continued, although affected by a profound faunal shift from rudist-coral-stromatoporoid communities to Lithocodium-Bacinella dominance.

In Aptian sequences, major and minor fluctuations of the carbon isotope record allow the subdivision of segments coded (C1-C11) by Menegatti et al. (1998) and Bralower et al. (1999). In particular, OAE 1a is marked by a complex $\mathrm{C}$ isotopic anomaly that has been recognized in the Tethys, North Atlantic, and Pacific Oceans (Weissert, 1989; Weissert and Lini, 1991; Grötsch, 1993; Bralower et al., 1994, 1999; Jenkyns, 1995; Vahrenkamp, 1996, 2010; Ferreri et al., 1997; Menegatti et al., 1998; Erba et al., 1999; Jenkyns and Wilson, 1999; Luciani et al., 2001; Ando et al., 2002; Bellanca et al., 2002; Price, 2003; Immenhauser et al., 2005; Millán et al., 2009; Hu et al., 2012a; Huck et al., 2012; Bottini et al., 2014), and in terrestrial sequences (Gröcke et al., 1999; Hesselbo et al., 2000; Jahren et al., 2001; Heimhofer et al., 2003). An initial negative spike documented in marine and terrestrial records suggests a large input of isotopically light carbon into the ocean-atmosphere system, perhaps due to intensified volcanogenic $\mathrm{CO}_{2}$ emissions during the GOJE (Larson, 1991a; Weissert and Lini, 1991; Bralower et al.,
1994; Erba, 1994; Weissert et al., 1998; Menegatti et al., 1998; Larson and Erba, 1999; Price, 2003), methane liberation from gas-hydrate dissociation (Gröcke et al., 1999; Hesselbo et al., 2000; Jahren et al., 2001; Beerling et al., 2002; Heimhofer et al., 2003; van Breugel et al., 2007), or a combination of excess volcanogenic $\mathrm{CO}_{2}$ and gas-hydrate dissociation (Bellanca et al., 2002; Méhay et al., 2009).

During the late Aptian, massive eruptions related to early constructional phases of the Kerguelen LIP produced the southern Kerguelen Plateau (SKP) (Fig. 1). Environmental changes linked to the SKP are less obvious in the sedimentary record, with subtle changes in lithology and absence of global anoxic episodes. Stable carbon isotopes display a large positive excursion persisting after the end of OAE 1a in marine and terrestrial records, followed by an interlude of low $\delta^{13} \mathrm{C}$ values and later by another long-lived positive excursion in the late Aptian.

Short- and long-term temperature changes have been reconstructed for the latest Barremian through Aptian time interval using micropaleontological proxies (e.g., Kemper, 1987; Premoli Silva et al., 1989a, 1999; Hochuli et al., 1999; Herrle and Mutterlose, 2003; Heimhofer et al., 2004; Rückheim et al., 2006a; Mutterlose et al., 2009; Keller et al., 2011; McAnena et al., 2013; Bottini et al., 2014, 2015), stable oxygen isotopes (Weissert and Lini, 1991; Jenkyns, 1995; Menegatti et al., 1998; Luciani et al., 2001; Bellanca et al., 2002; Price, 2003; Ando et al., 2008; Millán et al., 2009; Kuhnt et al., 2011; Jenkyns et al., 2012; Hu et al., 2012a; Price et al., 2012; Maurer et al., 2012; Bottini et al., 2014), and biomarkers (Schouten et al., 2003; Dumitrescu et al., 2006; Mutterlose et al., 2010; Keller et al., 2011; McAnena et al., 2013; Bottini et al., 2014, 2015). A global warming marked OAE 1a, while generally cooler temperatures persisted in the late Aptian, as indicated by the presence of glendonites and possible ice-rafted debris at high latitudes (Kemper, 1987; Frakes and Francis, 1988; De Lurio and Frakes, 1999; Price, 1999).

Hong and Lee (2012) provided estimates of atmospheric $\mathrm{CO}_{2}$ concentrations during the Cretaceous and emphasized that in the Aptian values were oscillating from $<500 \mathrm{ppmv}$ to $>1000$ ppmv. After a peak of 1100-1300 ppmv at $115 \mathrm{Ma}$, a minimum of $\sim 450 \mathrm{ppm}$ is depicted in the late Aptian, although age attribution is affected by large errors $(113.5 \pm 5 \mathrm{Ma})$. The recent $p \mathrm{CO}_{2}$ reconstructions by $\mathrm{Li}$ et al. (2014) suggest Aptian values ranging from $\sim 1000$ to $\sim 2000$ ppmv, with minima ca. $124 \mathrm{Ma}$ and $113 \mathrm{Ma}$ and maximum values ca. $117 \mathrm{Ma}$, relative to the time scale of Gradstein et al. (2012).

Relatively unradiogenic seawater ${ }^{87} \mathrm{Sr} /{ }^{86} \mathrm{Sr}$ values across OAE 1a suggest fluxes of hydrothermal $\mathrm{Sr}$ from intensified ocean crust production, either from new or faster spreading systems or intraplate activity such as ocean plateaus (Ingram et al., 1994; Jones et al., 1994; McArthur, 1994; Bralower et al., 1997; Jones and Jenkyns, 2001; Burla et al., 2009). Low ${ }^{87} \mathrm{Sr} /{ }^{86} \mathrm{Sr}$ values persisted through most of the late Aptian, but the long residence time of $\mathrm{Sr}$ in the ocean ( $\sim 5 \mathrm{~m}$.y.) hampers high-resolution characterization, which can instead be achieved using Os isotopes because of its much shorter residence time (10-40 k.y.). The Os isotopic 
TABLE 1. COMPILATION OF PAPERS DOCUMENTING PALEONTOLOGICAL AND GEOCHEMICAL DATA FOR THE OAE 1a INTERVAL

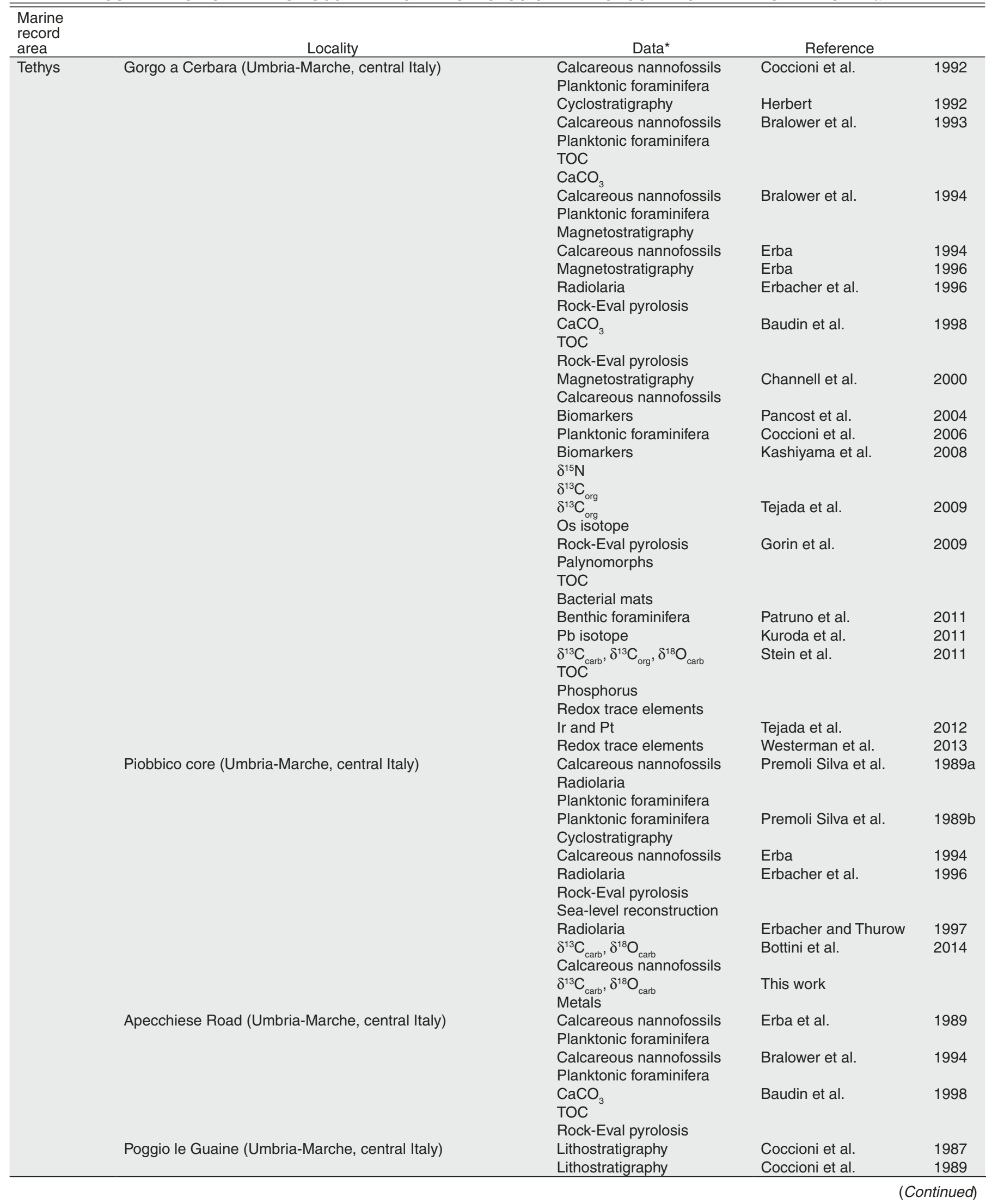


TABLE 1. COMPILATION OF PAPERS DOCUMENTING PALEONTOLOGICAL AND GEOCHEMICAL DATA FOR THE OAE 1a INTERVAL

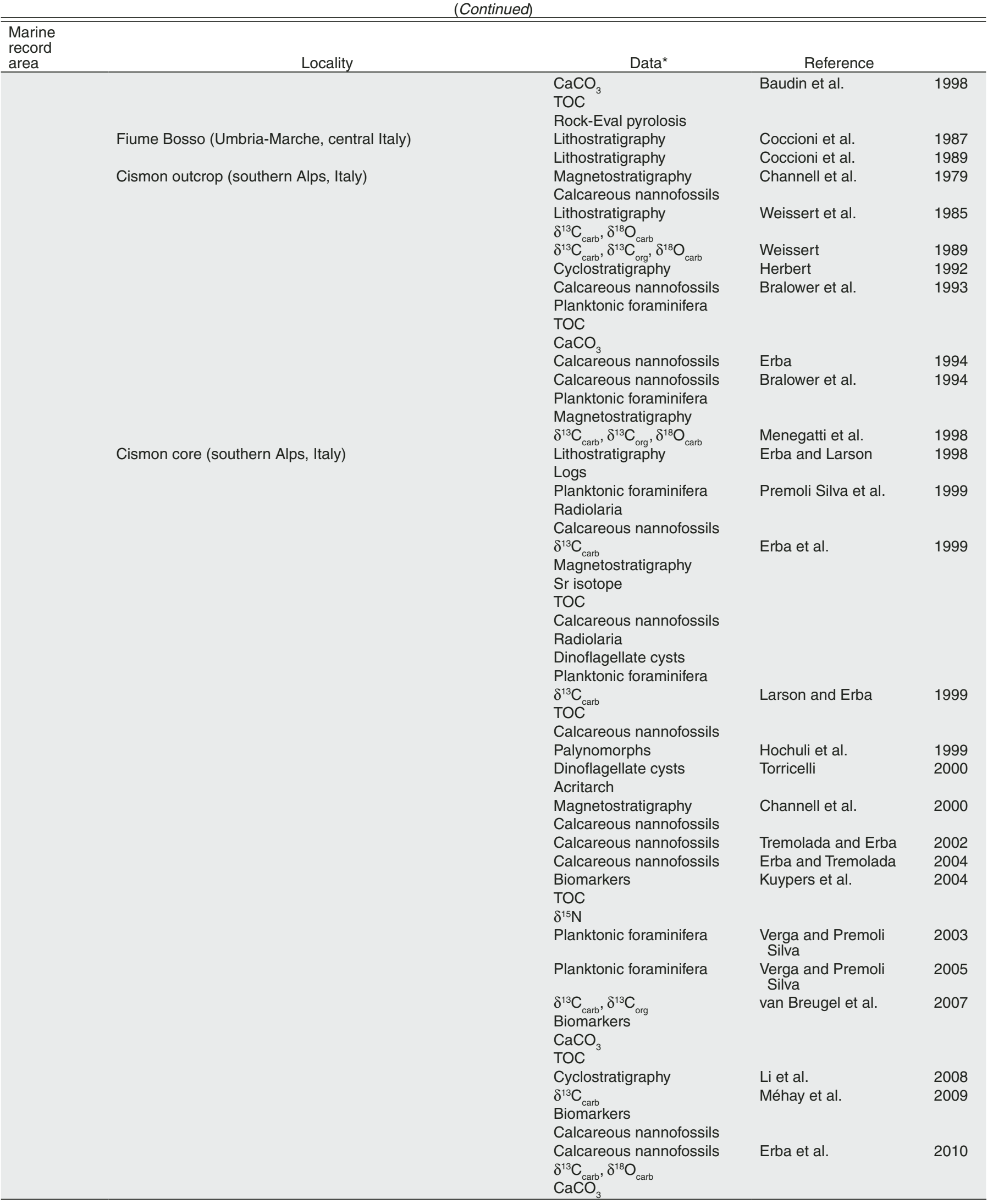


TABLE 1. COMPILATION OF PAPERS DOCUMENTING PALEONTOLOGICAL AND GEOCHEMICAL DATA FOR THE OAE 1a INTERVAL

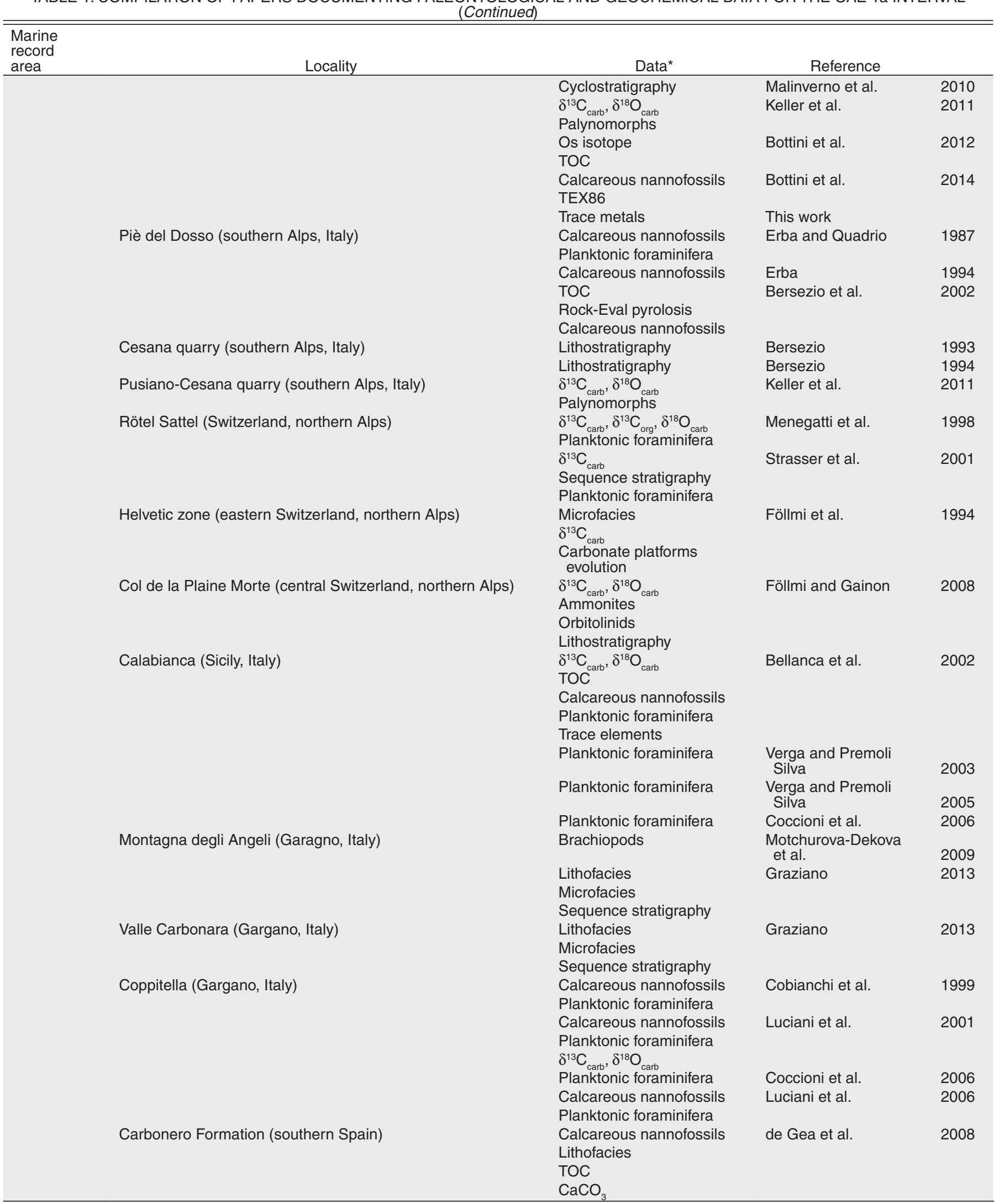


TABLE 1. COMPILATION OF PAPERS DOCUMENTING PALEONTOLOGICAL AND GEOCHEMICAL DATA FOR THE OAE 1a INTERVAL (Continued)

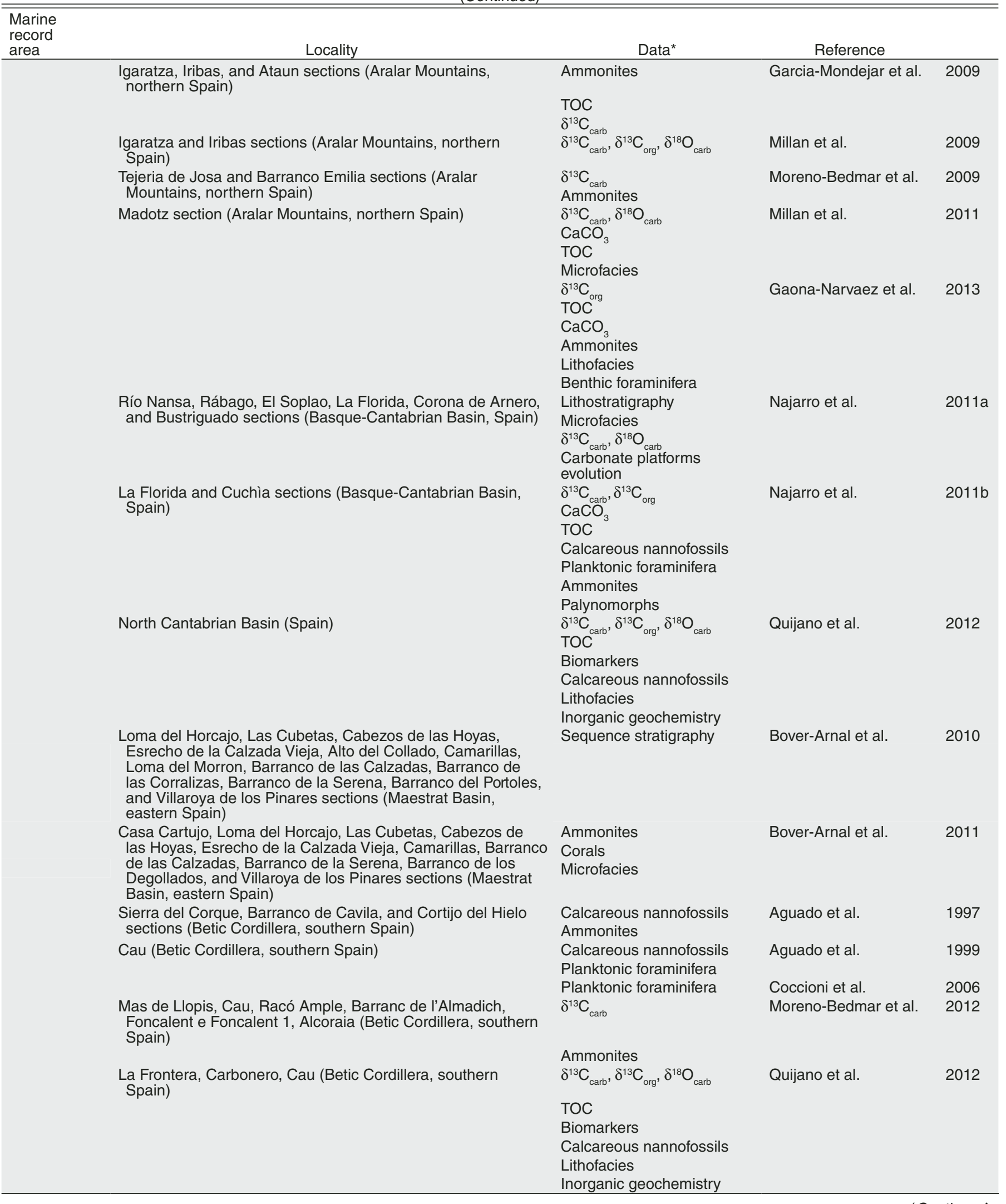


TABLE 1. COMPILATION OF PAPERS DOCUMENTING PALEONTOLOGICAL AND GEOCHEMICAL DATA FOR THE OAE 1a INTERVAL (Continued)

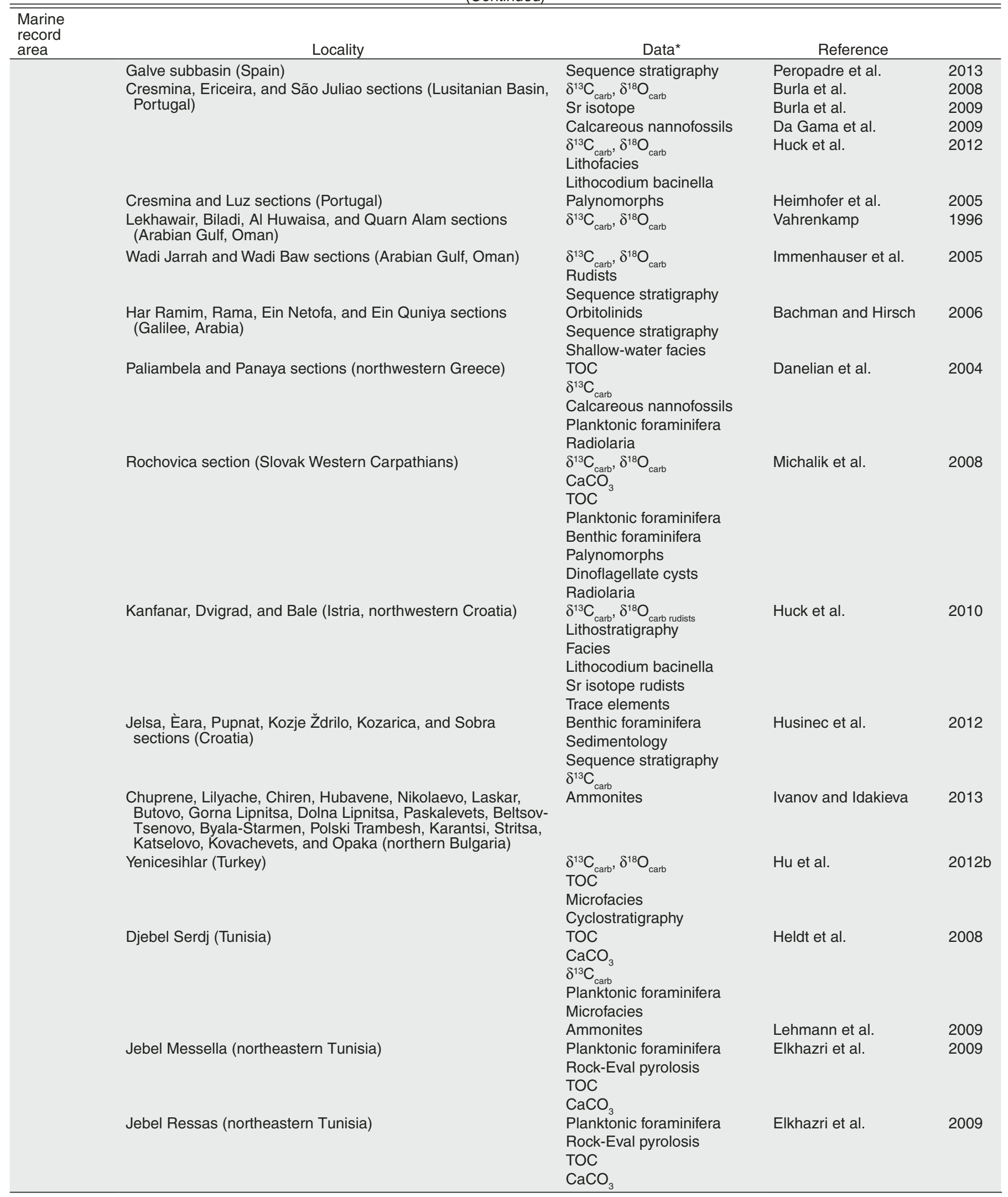


TABLE 1. COMPILATION OF PAPERS DOCUMENTING PALEONTOLOGICAL AND GEOCHEMICAL DATA FOR THE OAE 1a INTERVAL (Continued)

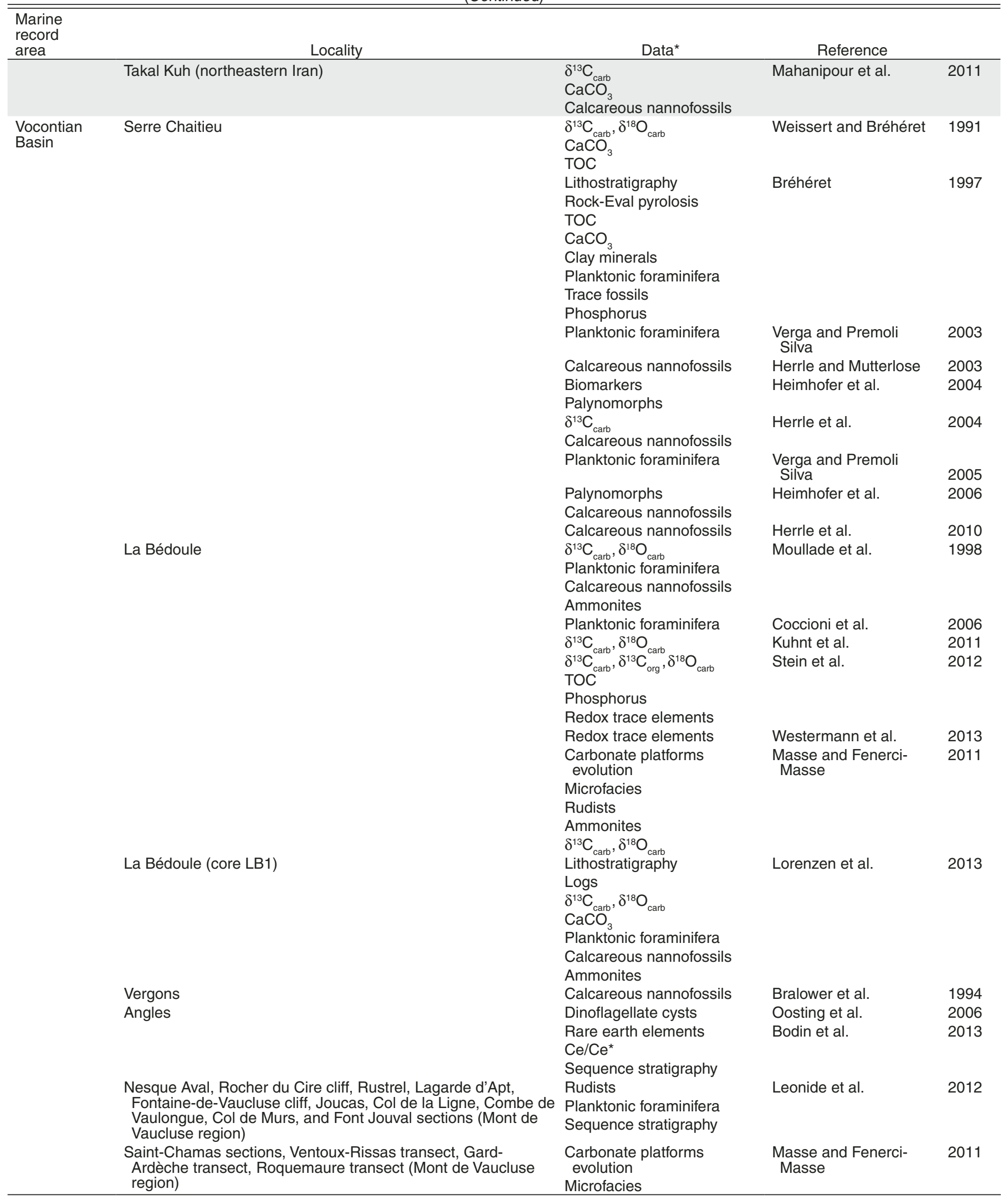


TABLE 1. COMPILATION OF PAPERS DOCUMENTING PALEONTOLOGICAL AND GEOCHEMICAL DATA FOR THE OAE 1a INTERVAL

\begin{tabular}{ll}
\hline $\begin{array}{l}\text { Marine } \\
\text { record } \\
\text { area }\end{array}$ & \multicolumn{1}{c}{ Locality } \\
\hline & Glaise (southeastern France) \\
& \\
& \\
Boreal Realm & $\begin{array}{l}\text { Hoheneggelsen KB50 core (Lower Saxony Basin, Germany) } \\
\text { Heligoland (Lower Saxony Basin, Germany) } \\
\text { Hoheneggelsen KB40 core (Lower Saxony Basin, Germany) }\end{array}$
\end{tabular}

\begin{abstract}
Ahlum 1 core (Lower Saxony Basin, Germany)
Morgenstern (Lower Saxony Basin, Germany)
\end{abstract}

A39 (Lower Saxony Basin, Germany)

Hoheneggelsen KB9 core (Lower Saxony Basin, Germany)

Alstätte 1 (Lower Saxony Basin, Germany)

Rethmar (Lower Saxony Basin, Germany)

\begin{tabular}{|c|c|}
\hline Data* & Reference \\
\hline
\end{tabular}

\section{Ammonites}

$\delta^{13} \mathrm{C}_{\text {carb }}, \delta^{18} \mathrm{O}_{\text {carb }}$

$\delta^{13} \mathrm{C}_{\text {carb }}, \delta^{13} \mathrm{C}_{\text {org }}, \delta^{18} \mathrm{O}_{\text {carb }} \quad$ Westermann et al.

2013

TOC

Redox trace elements

Phosphorus

Rare earth elements Bodin et al.

2013

$\mathrm{Ce} / \mathrm{Ce}^{*}$

Sequence stratigraphy

Calcareous nannofossils

Calcareous nannofossils

Major and minor elements

Calcareous nannofossils

$\delta^{13} \mathrm{C}_{\text {carb }}, \delta^{13} \mathrm{C}_{\text {org }}, \delta^{18} \mathrm{O}_{\text {carb }}$

Calcareous nannofossils

Calcareous nannofossils

$\delta^{13} \mathrm{C}_{\text {bel }}, \delta^{18} \mathrm{O}_{\text {bel }}$

Trace elements

Calcareous nannofossils

Ammonites

Belemnites

TOC

$\mathrm{CaCO}_{3}$

$\delta^{13} \mathrm{C}_{\text {bel, }}{ }^{3} \delta^{18} \mathrm{O}_{\text {bel }}$

$\delta^{13} \mathrm{C}_{\text {bel, }}, \delta^{18} \mathrm{O}_{\text {bel }}$

Trace elements

Calcareous nannofossils

Ammonites

Belemnites

TEX86

$\delta^{13} C_{\text {carb }}, \delta^{13} C_{\text {org }}$

Calcareous nannofossils

Trace elements

Calcareous nannofossils

$\delta^{13} \mathrm{C}_{\text {carb }}, \delta^{13} \mathrm{C}_{\text {org }}, \delta^{18} \mathrm{O}_{\text {carb }}$

$\mathrm{CaCO}_{3}$

TOC

Calcareous nannofossils

Planktonic foraminifera

$\delta^{13} \mathrm{C}_{\text {。 }}$

$\mathrm{CaCO}_{3}$

TOC

Calcareous nannofossils

$\delta^{13} \mathrm{C}_{\text {carb }}, \delta^{18} \mathrm{O}_{\text {carb }}$

TOC

$\mathrm{CaCO}_{3}$

Ammonites

Belemnites

Bivalves

Brachiopods

Gastropods

Crustacean

Asteroids

Plants

Calcareous nannofossils

$\delta^{13} \mathrm{C}_{\text {bel }}, \delta^{18} \mathrm{O}_{\text {bel }}$

Trace elements
Bischoff and Mutterlose 1998

Bischoff and Mutterlose 1998

Hild and Brumsack 1998

Habermann and 1999

Mutterlose

Heldt et al.

2012

Habermann and

Mutterlose

Malko et al.

1999

2010

Mutterlose et al.

2009

Malko et al.

2010

Mutterlose et al.

2010

Pauly et al.

2013

Bottini and Mutterlose

Heldt et al.

2012

2012

Weiß

2012

Bottini and Mutterlose

Lehmann et al.

2012

Bischoff and Mutterlose

1998

Malko et al.

2010 
TABLE 1. COMPILATION OF PAPERS DOCUMENTING PALEONTOLOGICAL AND GEOCHEMICAL DATA FOR THE OAE 1a INTERVAL (Continued)

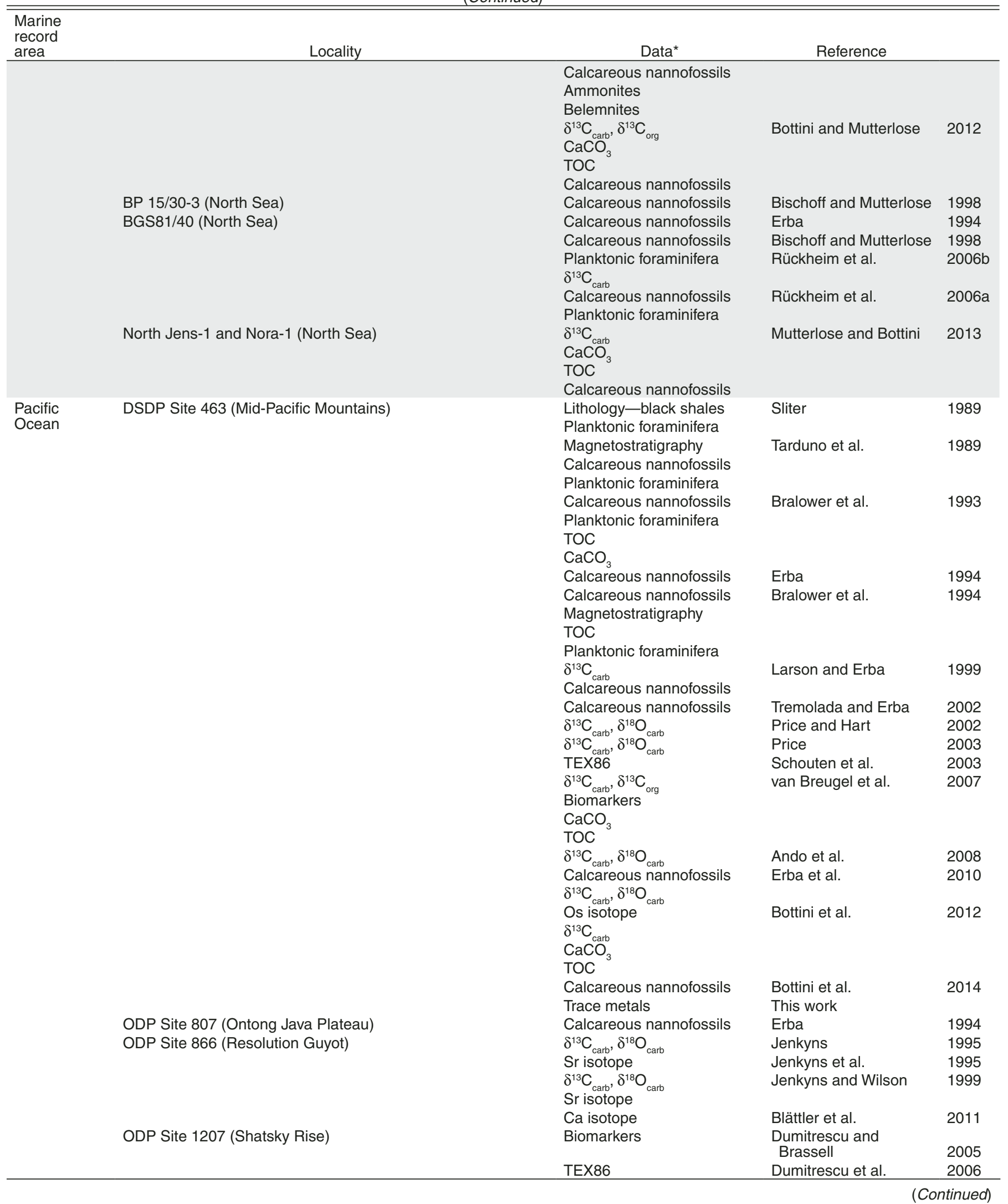


TABLE 1. COMPILATION OF PAPERS DOCUMENTING PALEONTOLOGICAL AND GEOCHEMICAL DATA FOR THE OAE 1a INTERVAL

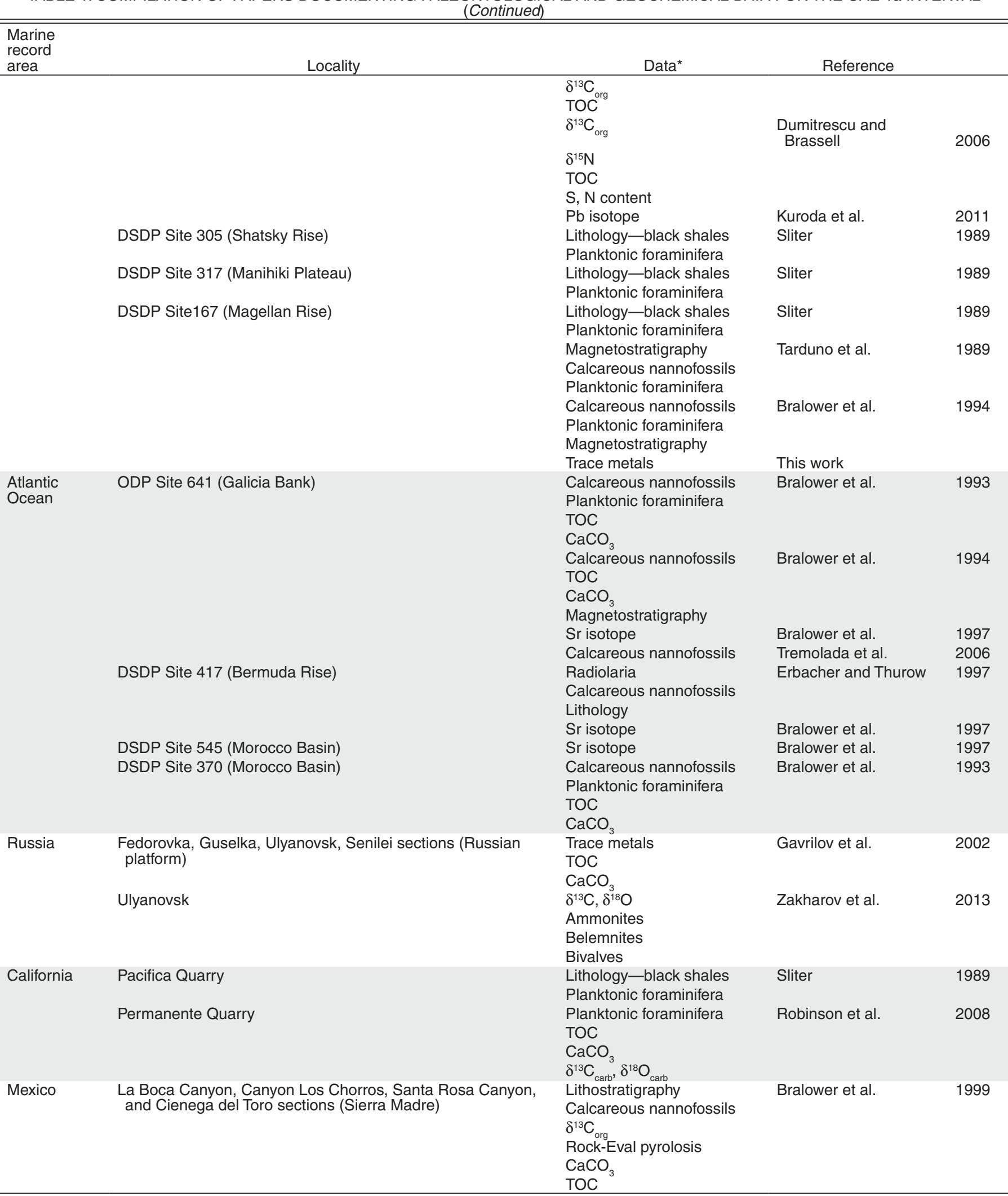


TABLE 1. COMPILATION OF PAPERS DOCUMENTING PALEONTOLOGICAL AND GEOCHEMICAL DATA FOR THE OAE 1a INTERVAL (Continued)

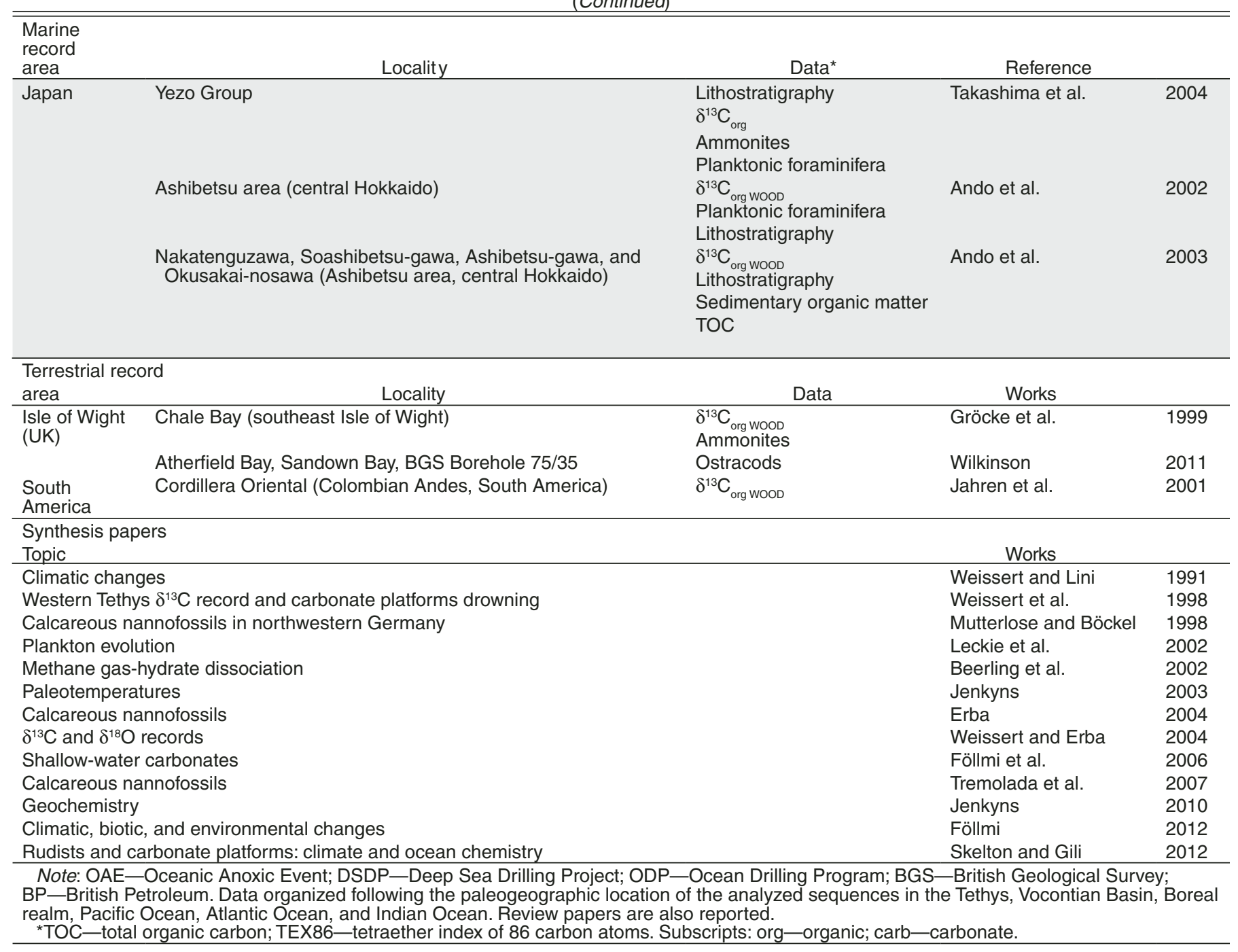

composition of seawater reconstructed for the Tethys and Pacific Oceans provides independent evidence of at least two major volcanic phases in the latest Barremian-early Aptian (Tejada et al., 2009; Bottini et al., 2012). No Os data are available for the late Aptian seawater.

Sedimentary $\mathrm{Pb}$ isotopic values from the Pacific and Tethys Oceans document temporal variations through the late Barremian-Aptian interval (Kuroda et al., 2011). The shift to unradiogenic $\mathrm{Pb}$ isotopic values in the Barremian-Aptian boundary interval is convincingly explained, as with $\mathrm{Sr}$ and $\mathrm{Os}$ isotopic profiles, by a significant increase in supply of unradiogenic lead from submarine volcanic eruptions and associated hydrothermal activity.

The major objective of this paper is to offer a comprehensive review of the micropaleontological, sedimentological, geochemical, and climatic changes during the latest Barremian-Aptian time interval. Moreover, we present new data for major, minor, and trace element abundances in sedimentary sections recovered from Deep Sea Drilling Project (DSDP) Sites 167 (Magellan Rise) and 463 (Mid-Pacific Mountains), Ocean Drilling Program (ODP) Site 866 (Resolution Guyot), and on land Cismon and Piobbico drill sites in Italy (Belluno and Umbria-Marche Basins, respectively) (Fig. 1). We test the proposal (Sinton and Duncan, 1997) that magmatic degassing and hydrothermal exchange during the formation of oceanic LIPs delivered buoyant, metal-rich plumes to the surface, and their subsequent distribution through the world oceans was governed by redox-related element solubility and water-mass circulation. These geochemical data are used to explore further the proposed links between submarine plateau volcanism associated with the GOJE (ca. $122 \mathrm{Ma}$ ) and OAE 1a. The patterns of metal abundance in the upper Aptian will provide the means to unravel submarine versus subaerial volcanic inputs during late phases of GOJE and/or early construction of the Kerguelen LIP. Analyzed sections are selected to quantify the 
element distribution in near-field and far-field locations relative to these proposed sources.

The chronology of major changes in climate and biota and oceanic structure, fertility, and chemistry is used to explore the possible roles of the GOJE and SKP. Comparison of volcanism style and intensity relative to paleoenvironmental perturbations and biotic response is aimed at assessing the complex and diversified consequences of LIP emplacement.

\section{TRACE METAL ABUNDANCES AS SIGNATURE OF LIP VOLCANISM}

The evidence from $\mathrm{Pb}$ and $\mathrm{Os}$ isotopic profiles for increased submarine volcanic activity at discrete times in the early Aptian is strong. New or faster seafloor spreading systems would not satisfy the observation that unradiogenic $\mathrm{Pb}$ inputs occurred (and then disappeared) over very brief intervals. However, the short time scales and enormous volumes of new crust in ocean plateau construction appear to satisfy the requirements of the isotopic data. Hydrothermal processes, in the form of both water-rock exchange and magmatic degassing during eruptions of single large lava flows on the seafloor or subsurface dike injections, introduce large concentrations of some elements (especially trace metals) that are variably volatile (in the gas phase) and variably soluble (in water-rock reactions) in the ocean (Rubin, 1997).

The magmatic fluids released during megaeruptions, mixed with ocean bottom water, have enough buoyancy to reach surface waters, especially if erupted from the shallow depths of ocean plateaus (Vogt, 1989). The element-enhanced waters could then be distributed throughout the oceans via surface circulation. Because many of these elements are biolimiting, their sudden appearance, especially in oligotrophic areas, would enhance (fertilize) primary production. The subsequent rain of excess organic material would then draw down oxygen levels in the deep ocean, leading to dysoxia or anoxia.

Increased elemental abundances, and changes from longterm seawater patterns, in sedimentary sections may also derive from enhanced terrigenous input, but the influence of factors such as spatial distribution, residence times, particle scavenging, and redox conditions must be also considered in any interpretation of sources. Hild and Brumsack (1998) documented Cd, Mo, Ni, $\mathrm{Pb}$, and $\mathrm{Se}$ enrichments in the lower Aptian Fischschiefer interval from the Hoheneggelsen KB 40 drill core (northwestern Germany), and lower Aptian black shales from the Russian Platform of relatively similar facies show comparable metal abundances (Gavrilov et al., 2002). Such variations in major and minor elements are attributed to a change in the source area of the detrital input and/or to accelerated weathering during OAE 1a. The onset of dysoxic to anoxic sedimentation and enhanced burial of organic matter might also be crucial for high concentrations of biophilic elements and some metals. The major, minor, and trace elements in oceanic settings during the early Aptian seem more related to large pulses of hydrothermal activity sourced in the Pacific and Indian Oceans, reaching the western Tethys
Ocean and perhaps areas as distant as the Russian Platform and the Lower Saxony Basin.

If submarine volcanic activity occurred on a massive scale during OAE 1a, an increase in trace metals in the surface ocean water should be reflected in element abundances well above background values in the sediments accumulating at that time. Conversely, subaerial LIPs might induce, via enhanced weathering, detrital metal enrichments. To test this hypothesis, we analyzed major, minor, and trace elements in three Pacific and two Tethyan sequences of Aptian age. These sections are well constrained by integrated biostratigraphy, magnetostratigraphy, and chemostratigraphy, allowing precise dating of metal enrichments and correlations.

\section{METHODS}

We analyzed 851 bulk sediment samples from 5 different sites (DSDP Sites 463 and 167, ODP Site 866, Piobbico and Cismon cores) for major, minor, and trace element ( $\mathrm{Sc}, \mathrm{Cu}, \mathrm{Co}, \mathrm{Sn}$, $\mathrm{Cr}, \mathrm{Ni}, \mathrm{V}, \mathrm{Cd}, \mathrm{Ag}, \mathrm{Bi}, \mathrm{Se}, \mathrm{W}, \mathrm{Mo}, \mathrm{Sb}$ ) concentrations at the Keck Laboratory at the College of Earth, Ocean and Atmospheric Sciences, Oregon State University (USA). Sample lithologies vary from carbonates (chalks and limestones) to marlstones, cherts, siltstones, and black shales (DSDP and ODP Scientific Results volumes for Sites 167, 463, and 866; Erba et al., 1999; Premoli Silva et al., 1989a; Tiraboschi et al., 2009). Bulk samples $\left(2 \mathrm{~cm}^{3}\right.$ each) were first crushed and powdered using an agate mortar and pestle, then $\sim 50 \mathrm{mg}$ of powder were dissolved with $\mathrm{HF}, \mathrm{HNO}_{3}$, and $\mathrm{HCl}$ in a CEM Corporation MARS 5 microwave digester. This procedure included a high-heat, high-pressure protocol followed by a sequence of chemical evaporations. The dissolved samples were then diluted in a $\mathrm{HNO}_{3}$ solution. We determined 28 trace and minor element concentrations using an inductively coupled plasma-mass spectrometer (ICP-MS; a VG PQ-Excel) and 10 major element concentrations using ICP-atomic emission mass spectrometry (AES).

All elemental concentrations were normalized to $\mathrm{Zr}$. The only significant source of $\mathrm{Zr}$ to pelagic sediments is from terrigenous material, thus normalizing to $\mathrm{Zr}$ removes the effect of variable terrigenous input to these sediments. On the basis of analyses of blind duplicates and standards, the average error for most elements analyzed by ICP-MS is $\sim 10 \%(2 \sigma)$. However, some elements ( $\mathrm{Sc}, \mathrm{V}, \mathrm{Ni}, \mathrm{Sn}, \mathrm{Sb}, \mathrm{Cs}$, and Bi) exhibited errors of $\sim 15 \%$ and a group that includes $\mathrm{Ag}, \mathrm{Au}$, and Se exhibited errors of $\sim 21 \%$; because of this larger instrumental uncertainty, inferences from this latter group should be treated with more caution. Errors for the ICP-AES analyses generally ranged from $3 \%$ to $8 \%$. Selected trace element (mainly trace metal) concentrations (ppb) are plotted against stratigraphic position in Figure 2; all variations are correlated with biostratigraphic, magnetostratigraphic, and chemostratigraphic data.

New $\mathrm{C}$ isotopic data are presented here for the Aptian interval of the Piobbico core. Bulk samples were first powdered, treated with acetone, and then dried at $60{ }^{\circ} \mathrm{C}$. Powders were then 

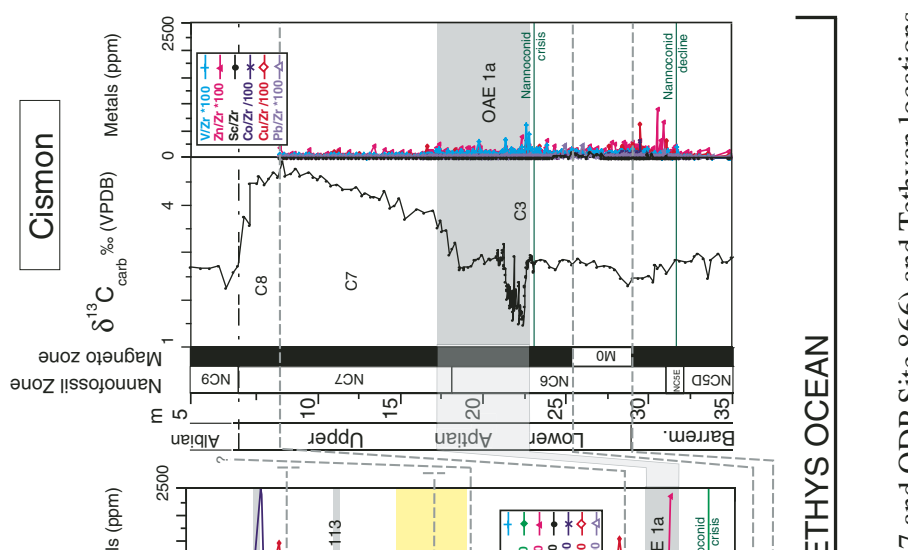

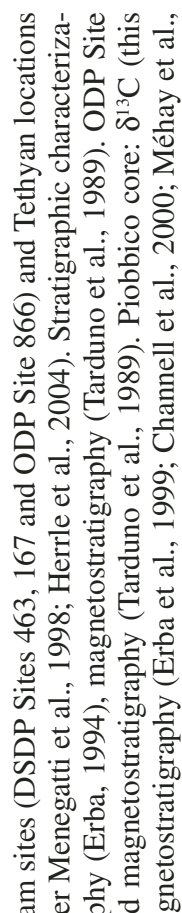

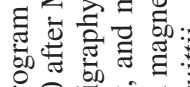

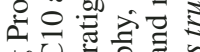

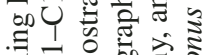

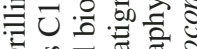

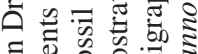

ॠี

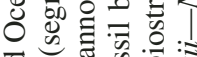

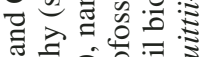

प्ते

. 행뮤 离

氜

on के तै

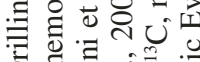

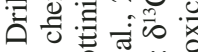

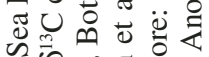

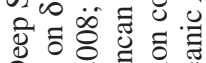

๑ั ర્ठ

过

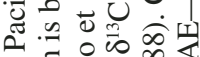

효

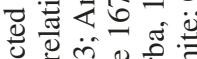

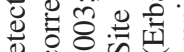

0 0 त

\&

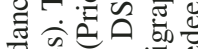

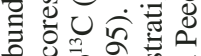

तै

플

U.

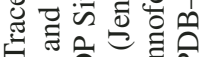

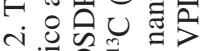

家

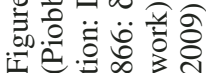


reacted with purified orthophosphoric acid at $90{ }^{\circ} \mathrm{C}$ and analyzed online using a VG Isocarb device and Prism Mass Spectrometer at Oxford University. Normal corrections were applied and the results are reported, using the usual delta $(\delta)$ notation, in per mil deviation from the Vienna Peedee belemnite (VPDB) standard. Calibration to VPDB was performed via the laboratory Carrara marble standard. Reproducibility of replicate analyses of standards was generally better than $0.1 \%$ ofor both carbon and oxygen isotope ratios.

\section{RESULTS}

Major, minor, and trace element abundance peaks are observed at coeval stratigraphic intervals in the studied sequences, although abundances and relative proportions of these elements are quite different among the five locations. Metal anomalies found in the Pacific sites are 10-1000 times higher than those detected in the Tethyan sites (Figs. 2 and 3). In the Pacific Ocean, element anomalies (mainly $\mathrm{Ag}, \mathrm{Ba}, \mathrm{Cd}, \mathrm{Cu}, \mathrm{Cr}, \mathrm{Ni}, \mathrm{Pb}, \mathrm{Sc}, \mathrm{Se}$, and $\mathrm{Zn}$ ) are detected in the interval between magnetochron $\mathrm{CM} 0$ and the second carbon isotope maximum (C9). An older interval of metal enrichment, from below CM0 into the Selli event (mainly $\mathrm{Cr}, \mathrm{Ni}, \mathrm{Pb}, \mathrm{Se}, \mathrm{V}$, and $\mathrm{Zn}$ ) is observed to varying extents at all three sites; a younger interval, from the Selli event through $\mathrm{C}$ isotope segments $\mathrm{C} 7, \mathrm{C} 8$, and at least $\mathrm{C} 9$ (tapering off in $\mathrm{C} 10$ at DSDP Sites 463 and 167), shows strong peaks in $\mathrm{Ag}, \mathrm{Pb}, \mathrm{Sc}$, $\mathrm{Se}, \mathrm{V}$, and $\mathrm{Zn}$. In detail, the variations occur as in the following.

- At DSDP Site 463, high abundances are identified in the lower Aptian (from the base of magnetochron CM0 up to the base of the Selli Level equivalent) and within the Selli Level equivalent (one peak in the central part and one at the top). The elements showing the highest abundances are $\mathrm{V}, \mathrm{Ni}, \mathrm{Zn}, \mathrm{Cr}, \mathrm{Ba}, \mathrm{Rb}, \mathrm{Se}, \mathrm{Cd}, \mathrm{Ag}, \mathrm{Hg}$, and Ti. The upper Aptian is characterized by high abundances in $\mathrm{Ag}, \mathrm{Pb}, \mathrm{Sc}$, $\mathrm{Se}, \mathrm{V}$, and $\mathrm{Zn}$. Small abundance peaks of $\mathrm{Cu}, \mathrm{Co}, \mathrm{Cr}$, and $\mathrm{Ni}$ are also detected, corresponding with the top of segment $\mathrm{C} 7$ through to the lower part of segment C10.

- At ODP Site 866, the highest abundances (Ag, Cd, Co, $\mathrm{Cu}, \mathrm{Ni}, \mathrm{Pb}, \mathrm{Rb}, \mathrm{Se}, \mathrm{Rb}, \mathrm{Th}, \mathrm{U}$, and $\mathrm{Hg}$ ) are identified just before OAE 1a in the top part of $\mathrm{C}$ isotope segment $\mathrm{C} 7$ and through segment $\mathrm{C} 8$ ( $\mathrm{Ag}, \mathrm{Co}, \mathrm{Cu}, \mathrm{Mo}, \mathrm{Pb}, \mathrm{Rb}, \mathrm{Se}, \mathrm{Th}, \mathrm{Ti}$, $\mathrm{U}, \mathrm{Zn}$, and $\mathrm{Hg}$ ).

- At DSDP Site 167, high abundances (Ag, Cs, Ni, Pb, $\mathrm{Re}, \mathrm{Rb}, \mathrm{Sr}, \mathrm{Ti}, \mathrm{Th}$, and $\mathrm{U}$ ) coincide with the uppermost Barremian-lowermost Aptian interval, before OAE 1a. Higher peaks (Ba, Cs, Cu, Pb, Ni, Rb, Se, $\mathrm{Sr}, \mathrm{Ti}, \mathrm{Th}, \mathrm{U}$, $\mathrm{V}$, and $\mathrm{Zn}$ ) are detected in $\mathrm{C}$ isotope segments $\mathrm{C} 8$ and $\mathrm{C} 9$.

In the Tethys Ocean sites (Piobbico and Cismon), the distribution of elemental abundances shows similarities to and differences from the Pacific sites. Abundance anomalies (mainly $\mathrm{Zn}, \mathrm{Co}, \mathrm{V}$, and Mo) show peaks just below magnetochron CM0, within the Selli Level and up into C isotopic segments C7-C10. The interval of the late Aptian $\mathrm{C}$ isotopic excursion (segments $\mathrm{C}$, $\mathrm{C} 10$ ) is enriched in some metals (e.g., $\mathrm{Cu}, \mathrm{Co}$, and $\mathrm{Bi}$ ), while near-background levels are observed through much of segments C7 and C8. In detail, the variations recorded in the Tethyan sections are described as in the following.

- In the Piobbico core, high abundances (Ag, $\mathrm{Au}, \mathrm{Ba}, \mathrm{Cd}$, $\mathrm{Co}, \mathrm{Cr}, \mathrm{Hg}, \mathrm{Mo}, \mathrm{Se}, \mathrm{Sr}, \mathrm{V}$, and $\mathrm{Zn}$ ) are detected within and especially just above the Selli Level. The upper Aptian is characterized by low abundances except for peaks of $\mathrm{Ag}$, $\mathrm{As}, \mathrm{Bi}, \mathrm{Co}, \mathrm{Cu}, \mathrm{Pb}, \mathrm{Ti}$, and $\mathrm{U}$, correlating with the end of the Nannoconus truittii acme interval and the Killian event (C isotopic segments $\mathrm{C} 9$ and $\mathrm{C} 10$ ).

- In the Cismon core, a peak ( $\mathrm{Zn}, \mathrm{Cu})$ occurs just below magnetochron CM0 and highest values continue through the top of the Selli Level. A significant increase (in V and Zn) marks the onset and the middle part of OAE 1a. Above the Selli black shales up to segment C7, metal concentrations remain low. Segments C8-C10 are missing at this site.

Because these elements can be released during volcanic activity in two modes, high-temperature, discrete magmatic degassing associated with single large eruptions, or lowtemperature, long-term water-rock reactions, we can expect different abundance patterns at different times depending on which process was dominant. According to Rubin (1997), highly volatile elements such as $\mathrm{B}, \mathrm{Bi}, \mathrm{Cd}, \mathrm{Se}, \mathrm{Hg}, \mathrm{Ag}, \mathrm{Pb}, \mathrm{Au}, \mathrm{Cu}, \mathrm{As}$, $\mathrm{Zn}, \mathrm{Tl}, \mathrm{In}, \mathrm{Re}, \mathrm{Sn}$, and Mo are concentrated in magmatically degassed fluids released only during eruptions. Elements that are less volatile, such as $\mathrm{Fe}, \mathrm{Mn}, \mathrm{Ba}, \mathrm{V}, \mathrm{Sr}, \mathrm{Sc}, \mathrm{Co}, \mathrm{Cr}, \mathrm{Ni}$, and $\mathrm{Rb}$ are more likely found in higher concentrations in water-rock exchange reactions of typical steady-state hydrothermal vents. Elemental abundance patterns at these five sites reveal contributions from both nonvolatile and volatile elements. The presence of these abundance peaks (normalized to $\mathrm{Zr}$ ) indicates that concentrations of metals in the ocean at these sites were increased by some mechanism other than influx of terrigenous sediment. The variation in total organic carbon (TOC), a function of local productivity and degree of ocean oxygenation, does not correlate with the position of the metal peaks (Fig. 3), suggesting that redox conditions at the sediment-water interface or increased scavenging of metals by sinking organic particles cannot explain all of the trace element abundance variability. Redox-sensitive elements can certainly be precipitated and retained at the sediment-water interface (Westermann et al., 2013). However, trace element abundances at northwestern Tethys locations (Gorgo a Cerbara, Glaise, and Cassis-La Bedoule) occur at the same intervals (preceding and within the Selli Level), but magnitudes correlate with degree of anoxia. Bodin et al. (2013) used Ce/Ce* anomalies observed in northwestern Tethys locations to track the rising ocean oxygen content from late Barremian to early Aptian time, followed by an interval of strong oxygen depletion. The fact that we observe the largest trace element abundance peaks before and after the interval of strongest oxygen depletion leads us to conclude that redox conditions exert only a secondary effect on these elemental variations.

An important aspect of the behavior of many trace elements is that once they enter the oceanic environment, they 


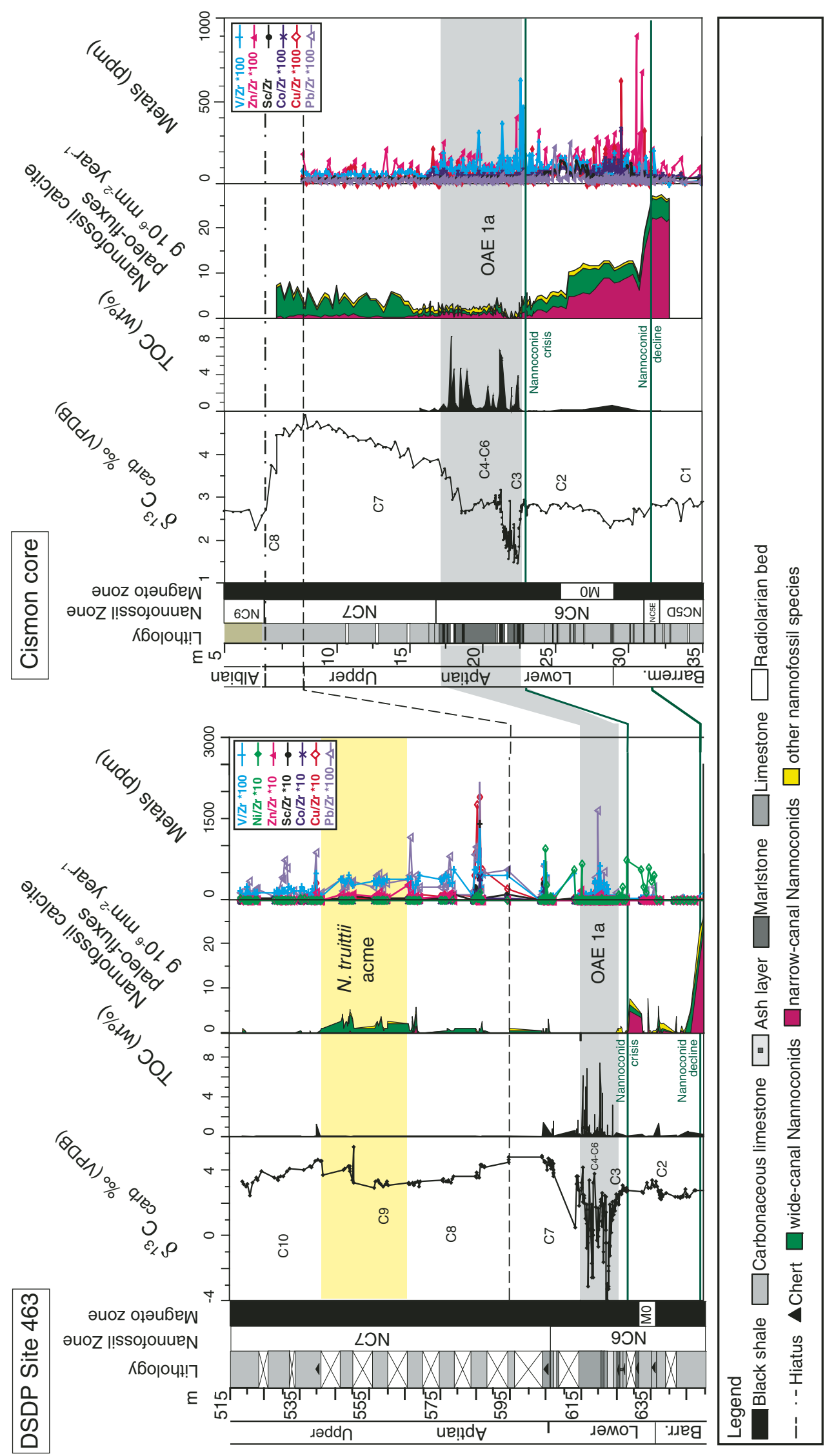

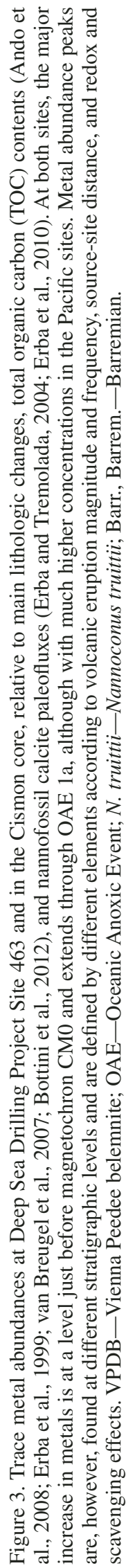




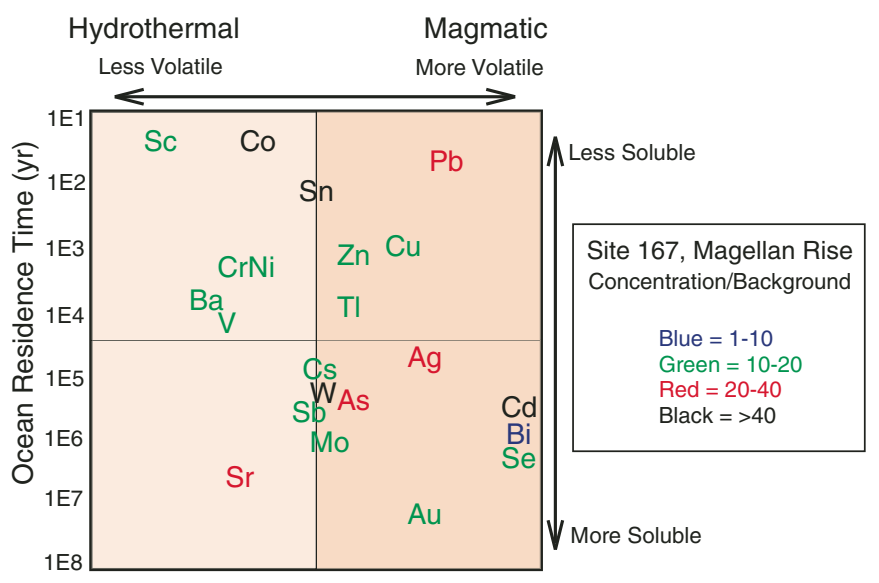

Figure 4. Relative partitioning of trace elements into the gas phase released during magmatic events and water-rock hydrothermal exchange reactions (volatility) versus ocean residence times (solubility and bioreactivity) are used to track elements released during submarine volcanism (after Rubin, 1997). Example shows the pattern of element concentration anomalies (above background levels) for bulk sediment at $920 \mathrm{~m}$ below seafloor at Deep Sea Drilling Project Site 167, Magellan Rise.

become biologically active (in metabolic processes) and chemically reactive (in inorganic reactions), and are removed from seawater by sinking organic matter (either bound or scavenged). Depending on how reactive they are, some will be removed very quickly, whereas others will remain in seawater much longer. This reactivity can be represented by the element's mean ocean residence time. For example, the behavior of elements in the strong abundance peak just below magnetochron CM0 at DSDP Site 167 (Magellan Rise) can be evaluated in a plot of volatility versus residence time (Fig. 4). While all elements show some degree of enrichment, those that are more volatile are generally more enriched (abundances 20-40 times background levels) compared with elements that are less volatile, $<20$ times background levels, which suggests the strong contribution of magmatic degassing in discrete submarine eruptions. The high abundance of elements with shorter residence times (e.g., Pb, $\mathrm{Co}, \mathrm{Zn}$ ) may indicate that this site was near the source rather than far field in terms of geography.

The distribution of abundance peaks, especially for elements with shorter residence times, provides information about time and space variability to evaluate the proposal that the OJP is the source of volcanic activity related to OAE 1a. The effects of mixing and dilution, and removal of elements via primary production and scavenging, will produce a concentration gradient along surface circulation flow lines (Fig. 1). In Figure 5, we plot magnitude of element abundance peaks (peak/background) against distance measured along modeled mid-Cretaceous surface ocean circulation paths (Hay, 2009). Clearly, the elemental abundance patterns for both short and long residence time geochemical species are consistent with a Pacific source such as the GOJE. The strong anomalies for both volatile and nonvolatile elements indicate the contribution of magmatic degassing and hydrothermal exchange.

Differences exist principally between Pacific sites and Tethyan sites (Fig. 2), reflecting the major effect of distance from source. There is a substantial degree of coherence among the 3 Pacific sites close to the GOJE (Fig. 1), although peak magnitudes vary by a factor of 2-3 from Site 167 (larger) to 866 (smaller). These differences among nearby sites may be related to bioreactivity and scavenging, and local environmental conditions such as water depth and redox chemistry at the sediment-water interface.

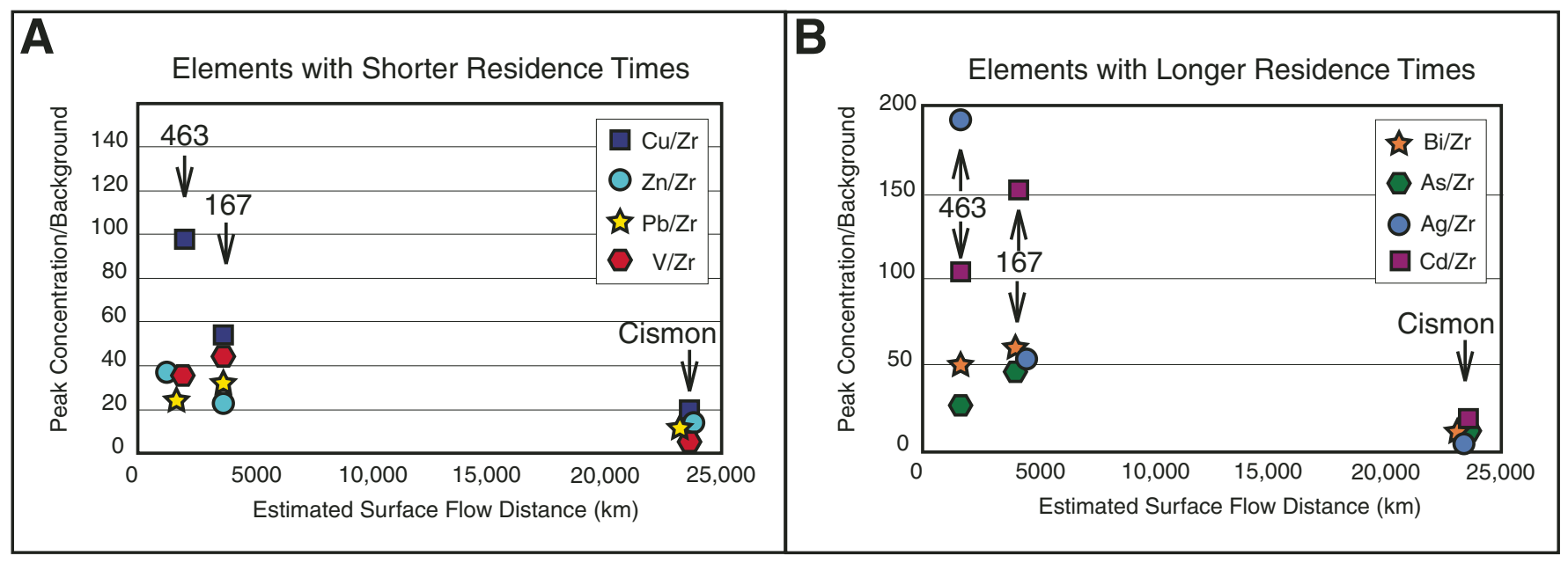

Figure 5. Trace element abundances decrease with distance from Ontong Java Plateau (determined along surface flow lines; see Fig. 1). (A) For elements with shorter oceanic residence times. (B) For elements with longer oceanic residence times. Element concentrations are first normalized to $\mathrm{Zr}$ concentration to remove the effect of minor but variable terrestrial input. Then peak concentration anomalies are divided by background values. Representative elements are shown from Oceanic Anoxic Event (OAE) 1a intervals at Deep Sea Drilling Project Sites 463 and 167 and the Cismon drill site. 


\section{DIRECT AND INDIRECT CONSEQUENCES OF LIP VOLCANISM ON ECOSYSTEM FUNCTIONING DURING THE APTIAN}

A critical step in obtaining a reliable chronology of the paleoenvironmental and biospheric changes and the duration of various events is high-resolution integrated biostratigraphy, magnetostratigraphy, and chemostratigraphy. As synthesized in Table 1, several studies conducted on sedimentary sequences through OAE 1a are based on large amounts of stratigraphic data, resulting in accurate evaluation of synchroneity and diachroneity of events and reproducibility of their relative timing. Some cyclostratigraphic studies of Barremian-Aptian sections have provided a quantitative estimate of durations of single events (Herbert et al., 1995; Li et al., 2008; Huang et al., 2010; Malinverno et al., 2010).

In Figure 6 we plot Aptian environmental changes against chronostratigraphy and geochronology according to the time scales of Malinverno et al. (2012) and Gradstein et al. (2012). Although these time scales provide ages for the base of the Aptian (equated to the base of magnetochron CM0) that are 4.8 m.y. apart, we decided to use both for comparison because they are constructed using different approaches. Malinverno et al. (2012) updated the Channell et al. (1995) M-sequence geomagnetic polarity time scale by incorporating marine magnetic anomaly records from several spreading centers worldwide (Tominaga and Sager, 2010), the radiometric age of magnetochron CMO (He et al., 2008), and astrochronology-based estimates of the duration of the magnetochron CM0-CM3r interval (Fiet and Gorin, 2000; Malinverno et al., 2010). The Gradstein et al. (2012) time scale represents a revision of the 2004 time scale (Gradstein et al., 2004), incorporating new methods and data, improved resolution and accuracy of radiometric dating, and stratigraphic standardization of stage and series boundaries.

Neither of these time scales has been uncontrovertibly shown to be wrong or correct. We emphasize that, in our schemes, the durations of biozones and of the early Aptian $\mathrm{C}$ isotopic anomaly remain the same in the two time scales because we adopt the astrochronology resolved by Malinverno et al. (2010) that is independent of ages of stage boundaries. However, durations of the late Aptian as well as of biotic and geochemical anomalies are quite different due to considerable variance of ages attributed to the Barremian-Aptian and Aptian-Albian boundaries.

Fingerprints of LIP volcanism are preserved in sedimentary sections and can be decoded using a variety of paleontological, sedimentological, and geochemical proxies. Most important is the amount of $\mathrm{CO}_{2}$ emitted during the construction of gigantic plateaus that control climatic conditions and weathering rates and extent. Moreover, the $\mathrm{CO}_{2}$ concentration in the ocean-atmosphere system affects biochemical processes during calcification and production of organic matter. In general, excess $\mathrm{CO}_{2}$ induces a decrease of carbonate saturation state in the oceans, affecting and perhaps hampering calcification of benthic and planktonic organisms from shallow-water settings to the open ocean (Berner and Beerling, 2007; Hönish et al., 2012). The complex sequence of paleoenvironmental and biotic changes detected in the latest Barremian through Aptian time interval are discussed in relation to the direct and indirect role of volcanism.

In uppermost Barremian sediments, calcareous nannofossil assemblages display an extensive decrease in abundance due to a worldwide nannoconid decline starting just before the beginning of magnetochron CM0 (Bralower et al., 1994; Erba, 1994, 2004; Erba and Tremolada, 2004; Tremolada et al., 2006, 2007; Erba et al., 2010), coeval with a substantial increase in trace element (particularly metal) concentrations (this study) and phosphorus abundance (Föllmi et al., 2006; Föllmi and Gainon, 2008). The drop in nannofossil abundance and paleofluxes is paralleled by an evolutionary speciation episode, without extinctions (Erba, 2004), with introduction of several new taxa, mostly represented by small coccoliths (e.g., Bown et al., 2004; Erba, 2006), perhaps reflecting a calcification strategy to survive harmful or simply rapidly varying water masses.

The coincidence of the nannoconid decline, the appearance of small taxa, and the metal enrichment is best explained by volcanic release of large quantities of $\mathrm{CO}_{2}$ and hydrothermal activity during the early phases of the GOJE. Metals might have additionally fertilized the oceans, contemporaneously favored by an increase in phosphorus, encouraging r-strategists and deleteriously affecting k-strategists such as nannoconids (Erba, 1994, 2004). A minor but well-defined $\delta^{13} \mathrm{C}$ decrease at the base of magnetochron $\mathrm{CM} 0$ is recorded globally and is taken as supplementary evidence of volcanogenically derived, isotopically light carbon in the ocean-atmosphere system during the initial stage of the GOJE. At the stratigraphic level of the nannoconid decline and metal abundance peak, both $\mathrm{Os}$ and $\mathrm{Sr}$ isotopes record a temporary decrease, further suggestive of submarine volcanism and/or hydrothermal input outweighing the effects of continental weathering (Bralower et al., 1997; Jones and Jenkyns, 2001; Bottini et al., 2012). An extensive review of changes in shallowwater platforms was provided by Skelton and Gili (2012), who explained the minor reduction of carbonate platforms in the latest Barremian, possibly due to a kettle effect (the thermal expulsion of aqueous $\mathrm{CO}_{2}$ due to warming) effectively contrasting $\mathrm{CO}_{2}$ enrichments.

After magnetochron $\mathrm{CM} 0$ and prior to OAE 1a the onset of the nannoconid crisis (Erba 1994) corresponds to a large biocalcification decrease, with a drop in pelagic biogenic calcite production of $\sim 80 \%$. A coeval increase in the nannofossil fertility index (Fig. 6) suggests that nutrient availability in surface waters intensified; this is supported by the phosphate curve (Föllmi et al., 2006; Föllmi and Gainon, 2008) and by radiolarite levels within OAE 1a (Coccioni et al., 1987). The response of benthic calcifiers includes a major shift in rudist composition and general dominance of microbial encrustations dominated by Lithocodium-Bacinella, locally associated with condensed sequences and hiatuses on drowned platforms (see the extensive review by Skelton and Gili, 2012). 

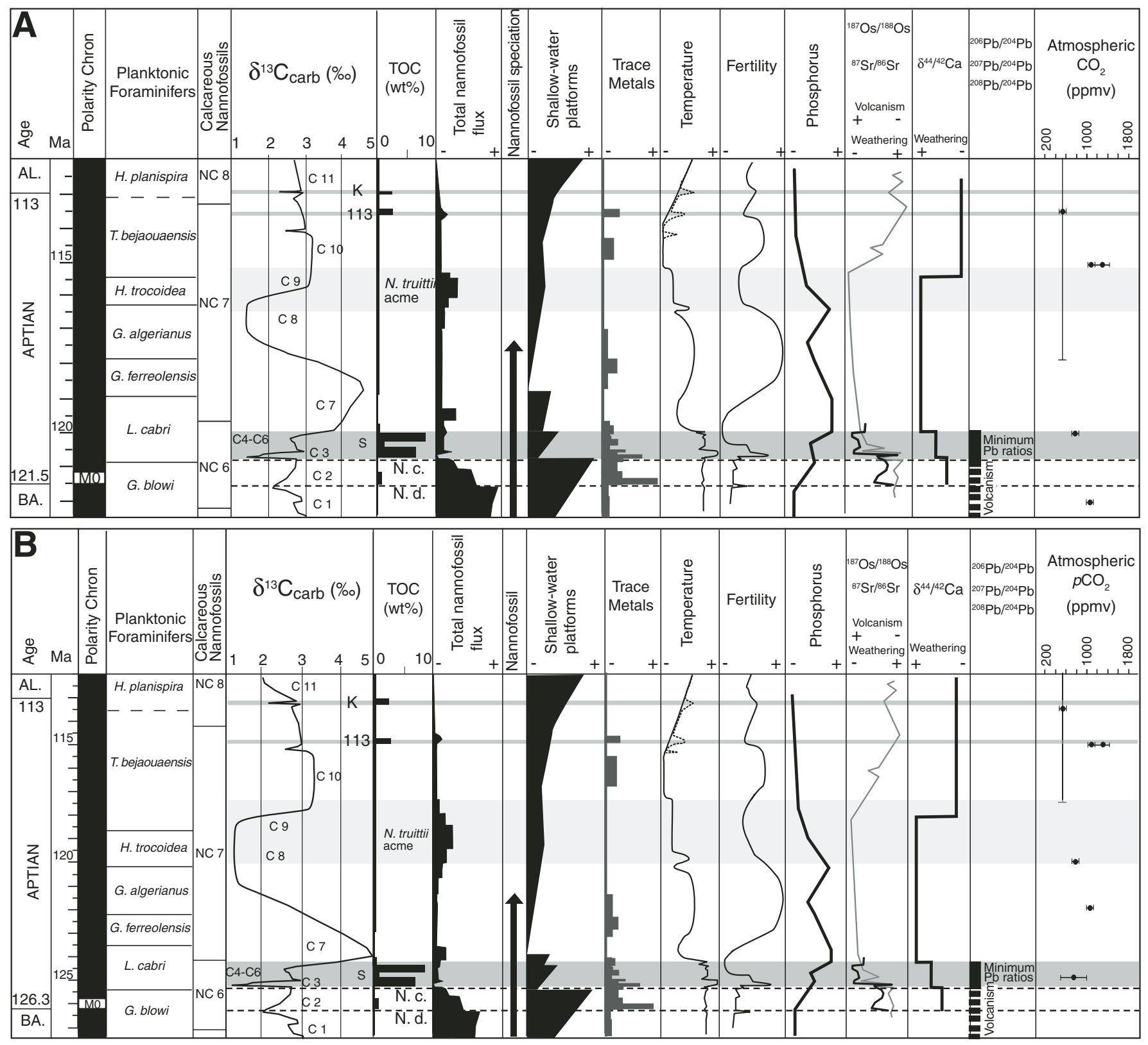

Figure 6. Latest Barremian (BA.) to earliest Albian (AL.) biotic and geochemical changes plotted within the chronologic framework based on nannofossil and planktonic foraminiferal biostratigraphy and magnetostratigraphy (Weissert and Erba, 2004). C isotopic stratigraphy is after Menegatti et al. (1998) and Bralower et al. (1999). Numerical ages in schemes A and B are based on time scales of Malinverno et al. (2012) and the geologic time scale of Gradstein et al. (2012), respectively. In both schemes the durations across the latest Barremian to the top of the NC6 nannofossil zone is based on astrochronology of Malinverno et al. (2010). Carbon isotope data: simplified composite curve is based on Erba et al. (1999), Weissert and Erba (2004), and Weissert et al. (2008). Total organic carbon (TOC) is after Bottini et al. (2012). Nannofossil calcite fluxes are simplified after Erba (1994), Erba and Tremolada (2004), and Erba et al. (2010). Trace metals: this work. Os isotopes are after Tejada et al. (2009) and Bottini et al. (2012). Sr isotopes are after Bralower et al. (1997) and Jones and Jenkyns (2001). Temperature curve is based on integrated oxygen isotopes (Weissert and Erba, 2004; Erba et al., 2010), nannofossil assemblages (Herrle and Mutterlose, 2003), palynomorphs (Hochuli et al., 1999; Keller et al., 2011), and TEX86 (tetraether index of tetraethers consisting of 86 carbon atoms; McAnena et al., 2013). Fertility: nannofossil assemblages (Tiraboschi, 2009; Erba et al., 2010). Phosphorus is after Föllmi (2012). Platform development and drowning is from Skelton and Gili (2012). Ca isotopes are from Blättler et al. (2011). Pb isotopes are from Kuroda et al. (2011). Atmospheric $\mathrm{CO}_{2}$ is from Hong and Lee (2012). K-Niveau Kilian; 113-Livello 113; S-Selli Level (Oceanic Anoxic Event OAE 1a) is indicated by a gray band. N.d.—Nannoconid decline; N.c.—Nannoconid crisis; G. blowi-Globigerinelloides blowi; L. cabri-Leupoldina cabri; G. ferreolensis-Globigerinelloides ferreolensis; H. Trocoidea-Hedbergella trocoidea; G. algerianus-Globigerinelloides algerianus; T. bejaouaensis—Ticinella bejaouaensis; H. planispira-Hedbergella planispira. 
Evidence for a biocalcification crisis followed by demise and drowning of the carbonate platform (sensu Schlager, 1981) is seen in the combined sedimentological and geochemical records from the Basque-Cantabrian Basin (Millán et al., 2009), an extended inner carbonate ramp succession (sensu Burchette and Wright, 1992) that underwent a temporary demise but not definitive drowning of the carbonate ramp. The negative spike in the carbon isotope record coincides with a change from neritic limestones to carbonate-poor shales deposited in a shallow ramp setting and reflecting increased weathering at a time of reduced carbonate production. However, only a few meters above the demise level the first occurrence of ammonites suggests that the calcification crisis was of limited duration and that organisms not living close to surface waters were less affected by the calcification crisis even if their shells were constructed of aragonite. Low carbonate content and elevated detrital material characterize the carbonate ramp succession of the Basque-Cantabrian Basin throughout OAE 1a. The carbonate ramp recovered after OAE1a and a few hundred meters of shallow-water limestones were accumulated during the time of the positive carbon isotope excursion (Millán et al., 2009).

Just below the stratigraphic level of OAE 1a, trace metals show an abundance peak and Os and $\mathrm{Sr}$ isotopes record a rapid change to less radiogenic values, while paleotemperatures rapidly increase. These proxies imply a likely major volcanic phase of the GOJE that introduced $\mathrm{CO}_{2}$ concentrations 3-6 times higher than before (e.g., Erba and Tremolada, 2004) and added biolimiting and/or toxic metals. The nannoconid crisis and the contemporaneous demise of carbonate platforms suggest that acidification in addition to eutrophication of surface waters contributed to a major biocalcification failure, although low-latitude carbonate platforms were less affected (Di Lucia et al., 2012), perhaps because of the kettle effect in near-tropical settings, compensating the impact of elevated atmospheric $\mathrm{CO}_{2}$ concentrations (Skelton and Gili, 2012).

The profound change in ocean chemistry, and specifically the decreased carbonate saturation state, is also recorded by condensation and locally partial dissolution of carbonates at the seafloor as a consequence of shoaling of the calcite lysocline, indicating a delay of several thousand years in the effects of volcanic $\mathrm{CO}_{2}$ on surface- versus bottom-water acidification (Erba et al., 2010).

Increased volcanic activity just before the onset of global anoxia and enhanced burial of organic matter is further demonstrated by the Os isotopic records in the Tethys and Pacific Oceans (Tejada et al., 2009; Bottini et al., 2012) and Pb isotopic profiles (Kuroda et al., 2011) that unquestionably reflect an OJP source. Unfortunately, the chronostratigraphic control of the $\mathrm{Pb}$ isotopic record at the Shatsky Rise is rather poor, mostly due to low recovery at ODP Site 1207 . The shift to unradiogenic $\mathrm{Pb}$ isotopic values certainly precedes OAE $1 \mathrm{a}$, but it is not possible to assign this $\mathrm{Pb}$ anomaly to either the nannoconid decline or the nannoconid crisis events.

Biomarker and nannofossil data allow the reconstruction of subsequent volcanic phases and stepwise accumulation of $\mathrm{CO}_{2}$ in the ocean-atmosphere system, causing ephemeral biocalcification changes and shoaling of the calcite compensation depth (CCD; Méhay et al., 2009, Erba et al., 2010; Bottini et al., 2012). The early phase of OAE 1a is marked by the final crash of nannoconids and extremely low nannofossil calcite paleofluxes, although total nannofossil abundance remained relatively high, with common mesotrophic taxa, substantial carbonate platform reduction, dissolution of carbonates at the seafloor, extreme warmth, increased fertility, and abundance peak of metals.

A major shift in primary producers occurred during OAE 1a when nitrogen-fixing cyanobacteria and/or upwelling of ammonium ions may have provided and sustained the necessary nutrient $\mathrm{N}$ for the functioning of the biological pump (Kuypers et al., 2004; Dumitrescu and Brassell, 2006). Cyanobacteria require trace metals for $\mathrm{N}_{2}$ fixation that is Fe limited and, therefore, illustrate a potential link between OAE 1a and submarine volcanism with metal fertilization (Larson and Erba, 1999; Leckie et al., 2002; Zerkle et al., 2008).

The Os isotopic record shows a rapid decrease to exceptionally unradiogenic values, most likely representing an intense phase of the GOJE. The occurrence of dwarf and malformed coccoliths in the restricted interval of negative $\mathrm{C}$ isotopic interval (Erba et al., 2010) is inferred to be the nannoplankton response to volcanically induced ocean acidification.

The high-resolution record of the Tethys Ocean shows a positive spike of Os isotopic ratios at the beginning of the negative $\delta^{13} \mathrm{C}$ spike, but this feature is not unambiguously duplicated in the Pacific Ocean, possibly due to low core recovery at DSDP Site 463. The Os spike is suggestive of accelerated weathering rates and increased runoff, at least at marginal settings (Tejada et al., 2009; Bottini et al., 2012), immediately after an abrupt warming and inferred injection of methane into the atmosphere (Méhay et al., 2009). In the Sr isotopic record (Bralower et al., 1997; Jones and Jenkyns, 2001) there is no evidence for a radiogenic spike. However, at ODP Site 866 on the Resolution Guyot, a single relatively radiogenic $\mathrm{Sr}$ isotope data point is recorded within the negative $\delta^{13} \mathrm{C}$ negative spike (Jenkyns and Wilson, 1999). It is interesting that $\mathrm{Ca}$ isotope data from the same site (Blättler et al., 2011) suggest an increase in weathering rates during the equivalent time interval, consistent with the observation of increased quartz-sand shedding into the western Tethys during the Aptian (Wortmann et al., 2004). The effects of temporary $\mathrm{CO}_{2}$ drawdown through (silicate) weathering are recorded by the brief cooling episode and relative nannofossil recovery immediately after the Os positive spike.

Within the Selli Level, the prolonged interval of unradiogenic Os ratios, associated with metal abundance peaks, suggests a major volcanic phase and intense hydrothermal activity of the GOJE, persisting through most of OAE 1a. The submarine volcanism of the OJP, however, probably fluctuated in intensity, which resulted in variable effects on weathering, temperatures, fertility, and organic matter accumulation. Soon after the negative $\delta^{13} \mathrm{C}$ spike, nannofossil total abundance and calcite paleofluxes show a first partial recovery, suggesting a progressive deepening of 
the calcite lysocline and CCD. Mesotrophic taxa were no longer affected by dwarfism, but they were still abundant, reflecting relatively high nutrient availability and reduced acidity of surface waters (Erba et al., 2010). These data suggest a general decrease in $p \mathrm{CO}_{2}$, favoring nannoplankton biocalcification under less extreme climatic conditions. The inferred $\mathrm{CO}_{2}$ decrease might have been the result of effective organic matter burial as well as weathering, together offsetting the input of volcanogenic $\mathrm{CO}_{2}$. Limited production of shallow-water carbonates continued to the end of OAE 1a (Millán et al., 2009), possibly due to relatively elevated nutrient levels and episodic $\mathrm{CO}_{2}$ pulses.

The latest phase of OAE 1a was marked by the onset of a cooling episode that coincided with the increase in $\delta^{13} \mathrm{C}$ values, a decrease in TOC content, more radiogenic Os isotopic values, and lower $\mathrm{CO}_{2}$ levels (e.g., Heimhofer et al., 2004). Moreover, the lessening of anoxic bottom-water conditions was coeval with decreasing metal abundances, the partial recovery of nannofossil abundance and paleofluxes, an increase of detrital phosphorus, and possibly enhanced weathering, as suggested by $\mathrm{Ca}$ isotopes. Burial of large amounts of organic matter and intensified weathering, perhaps during OJP quiescence, might have been crucial for considerable $\mathrm{CO}_{2}$ drawdown and atmospheric and seawater cooling. After OAE 1a, the relative recovery of carbonate platforms was substantially limited to platforms affected only by demise and not by drowning, and seems to have been controlled by cooling following OAE 1a. In shallow-water ecosystems, the recovery phase after OAE $1 \mathrm{a}$ was associated with a distinct change in rudist communities, i.e., aragonite-dominated taxa being depauperated while the calcite-dominated forms were only marginally affected (Steuber, 2002).

Weissert and Erba (2004) suggested a crucial role for excess volcanogenic $\mathrm{CO}_{2}$ and subsequent ocean acidification pulses for the carbonate crises through the late Aptian. During the time of the positive carbon isotope excursion following OAE 1a (segment C7), neritic carbonate production resumed in the BasqueCantabrian basin and as much as $400 \mathrm{~m}$ of shallow-water carbonates were deposited (Millán et al., 2009). Outer carbonate ramp successions affected by calcification crisis are preserved in Helvetic nappe pile of the Alps; these successions were deposited along the northern margin of the Tethys Ocean where the demise of the outer carbonate ramp was followed by drowning (Wissler et al., 2003).

Immediately after OAE 1a, an 1-m.y.-long cooling interval was followed by warm conditions preceding unstable late Aptian climate punctuated by relatively cold pulses (McAnena et al., 2013). The early late Aptian transient warmth correlates with increased metal abundances, increased nannofossil fertility indices, and relatively high phosphorus (Fig. 6), suggesting effective hydrothermal nutrification during a submarine volcanic episode.

The late Aptian N. truittii acme reflects a period of effective calcification under cooler conditions, suppressed fertility, and extremely low (close to background) metal abundances. Presumably, this was a time of quiescence in volcanism and reduced atmospheric $\mathrm{CO}_{2}$, promoting favorable conditions for heavily calcified forms to thrive, as also recorded by the growth of shallow-water carbonate platforms.

In the proto-North Atlantic, minimum temperatures (McAnena et al., 2013) were reached in the interval of moderate metal enrichment and increasing $\mathrm{Sr}$ isotopic values during the late Aptian. This was also the time of a final reduction in calcification and possibly extensive carbonate dissolution at the seafloor, as evidenced by calcareous nannoplankton (Erba, 2006; McAnena et al., 2013) and planktonic foraminifera (Huber and Leckie, 2011; Petrizzo et al., 2012), undergoing a major turnover in the Aptian-Albian boundary interval, possibly due to adverse chemistry of the ocean.

The occurrence of brief metal-rich intervals in late Aptian time suggests additional volcanic pulses during discrete constructional phases of submarine edifices, presumably releasing further large amounts of $\mathrm{CO}_{2}$ to the ocean-atmosphere system. The micropaleontological and geochemical anomalies detected in the interval encompassing the end of the Selli event and the Aptian-Albian boundary might be essentially or entirely related to early constructional phases of the Kerguelen LIP and major continental volcanism of the Rajmahal Traps of India (Coffin et al., 2002; Duncan, 2002; Frey et al., 2003).

During the late Aptian, under relatively colder conditions, the surface ocean was prone to heightened absorption of both $\mathrm{O}_{2}$ and $\mathrm{CO}_{2}$, hampering anoxia but provoking ocean acidification pulses and shallowing of the CCD. The late Aptian was characterized by a return to oxygenated bottom waters and a relative recovery of pelagic and neritic carbonate sedimentation. The latest Aptian nannoconid final collapse, coeval with the abundance drop in planktonic foraminifers, might be viewed as biocalcification failures under $\mathrm{CO}_{2}$-induced decreased calcite saturation state.

\section{EXCESS CO DURING LIP EMPLACEMENT: CLIMATE CHANGE AND OCEAN CHEMISTRY}

The earliest evidence of volcanism is observed just preceding magnetochron $\mathrm{CM} 0$, and intense volcanism continued through the early Aptian, with peaks at the onset of OAE 1a, followed by an 880-k.y.-long episode in the middle and upper parts of the Selli event. $\mathrm{Pb}$ isotopic profiles indicate the OJP, by far the largest oceanic LIP that formed rapidly at low latitudes in the Pacific Ocean, as the likely source of the geochemical anomalies detected in uppermost Barremian to lower Aptian sedimentary sequences in the Tethys and Pacific Oceans.

Evidence of large-scale volcanism during the late Aptian is less well documented, although three intervals of magmatic activity associated with suppressed biogenic carbonate production are inferred to be the result of significant hydrothermal submarine activity and excess $\mathrm{CO}_{2}$. In late Aptian time, volcanic activity on a massive scale constructed most of the SKP in the incipient Indian Ocean opening between India, Australia, and Antarctica at high southern latitudes (Coffin et al., 2002). The SKP volcanism was almost entirely subaerial, with a very early and short-lived 
submarine phase found at ODP Site 1136. Possible sources of the upper Aptian metal anomalies are the Hikurangi Plateau (Hoernle et al., 2010) and/or younger, post-major constructional phases of the OJP and Manihiki Plateau (Timm et al., 2011). Concomitantly, or alternatively, hydrothermal fields linked to the initial submarine volcanism of the SKP (Coffin et al., 2002; Duncan, 2002) might have been responsible for the metal enrichments.

GOJE and SKP magmatism would have released huge amounts of gases, major, minor, and trace elements, and particulates into the ocean-atmosphere system with impacts on climatic conditions and variability. Volcanic $\mathrm{CO}_{2}$ generally induces warming over long time scales, whereas volcanic ash and gases injected into the atmosphere may trigger transient cooling. In the OAE 1a interval, a total of $\sim 9600 \mathrm{Gt}$ of $\mathrm{CO}_{2}$ has been estimated to have derived from subsequent volcanic pulses of the OJP (Méhay et al., 2009). In late Aptian time, the SKP volcanism correlated with a period of excess $\mathrm{CO}_{2}$ (Retallack, 2001), although magma fluxes may have been an order of magnitude lower relative to the OJP emplacement (Eldholm and Coffin, 2000). This difference might, at least partially, explain why greenhouse conditions were not reached. During the late Aptian a first cool interlude correlates with the Globigerinelloides algerianus planktonic foraminiferal zone and another episode of colder conditions started in the Ticinella bejaouaensis planktonic foraminiferal zone, continuing up to the Aptian-Albian boundary (Figs. 6 and 7) with a total decrease of $\sim 4{ }^{\circ} \mathrm{C}$ in the proto-North Atlantic (McAnena et al., 2013).

Was the late Aptian a time of persistent cold climate (e.g., Price et al., 2012; Maurer et al., 2012) or was the post-OAE 1a climate affected by discrete ice age interludes, as suggested by Weissert and Lini (1991)? Late Aptian cool climate lasting as much as a few million years is counterintuitive, given extensive and repeated volcanism during emplacement of the Kerguelen LIP. Chemical weathering of rocks exposed on land is a relatively slow process for pulling down excess $\mathrm{CO}_{2}$, especially under persistent volcanic activity, and therefore alone seems an implausible cause for the late-late Aptian global cooling (Bottini et al., 2014, 2015). Burial of substantial amounts of organic matter in the Southern Ocean and in the South Atlantic over 2.5 m.y. has been postulated to have caused the late Aptian cooling (McAnena et al., 2013); however, organic carbon-rich black shales have not been documented, and well-oxygenated conditions characterized the late Aptian (e.g., Erba et al., 1989; Hu et al., 2012b).

Global climatic changes appear to be marginally significant for production of marine calcifiers, production that is remarkably buffered by the carbonate saturation state of the ocean. However, warm or cool climates control gas absorption in surface waters and, specifically, fluxes of $\mathrm{CO}_{2}$ from the atmosphere into the ocean. In Aptian time, fluctuations in volcanogenic $\mathrm{CO}_{2}$ in the ocean-atmosphere system affected marine biota; major changes in abundance and composition of calcifiers are undeniably recorded in neritic and pelagic settings at global scale. In particular, an inverse relationship between nannoplankton and shallowwater carbonates and LIP volcanism is documented through the latest Barremian-Aptian interval. We believe that major drops in biocalcification of planktonic and benthic communities during the early Aptian were arguably controlled by huge amounts of GOJE volcanogenic $\mathrm{CO}_{2}$ and ocean acidification. Likewise, in the late Aptian, resumptions and pauses in calcification paralleled quiescence and activity of LIP construction. In particular, the $N$. truittii acme, the only period of substantial nannofossil carbonate production, correlates with the absence of (or minimal) LIP magmatism and, therefore, with inferred attenuated $p \mathrm{CO}_{2}$.

The late-late Aptian cooler conditions would have amplified the absorption of $\mathrm{CO}_{2}$ in surface waters, promoting global acidification with suppressed carbonate production and shallowest CCD (Thierstein, 1979). However, the generally cooler climate of the late Aptian allowed amplified $\mathrm{O}_{2}$ absorption in surface waters and greater latitudinal gradients, promoting increased oxygenation and more efficient circulation of the oceans. This was a time without widespread anoxia.

\section{GEOCHRONOLOGY OF VOLCANIC ACTIVITY AND OF PALEOCEANOGRAPHIC EVENTS}

If there was a cause and consequence relationship between LIP construction and climatic-environmental changes, the timing of volcanic activity should match or be slightly older than the age of paleoceanographic events. The ${ }^{40} \mathrm{Ar} /{ }^{39} \mathrm{Ar}$ dating of the GOJE provides ages ranging from 126 to 117 Ma (Mahoney et al., 1993; Tejada et al., 1996, 2002; Chambers et al., 2004; Hoernle et al., 2010; Timm et al., 2011). More specifically, a compilation of radiometric ages from OJP basement lavas (Timm et al., 2011, fig. 2 therein) shows 19 of 24 dates (79\%) in the interval 124-120 Ma, which we take as the estimated age of the main plateau-building phase. The Manihiki Plateau primarily formed ca. 124.6 Ma, but later volcanic phases continued until ca. $117 \mathrm{Ma}$ (Timm et al., 2011), and the Hikurangi Plateau shows construction ages of 118-96 Ma (Hoernle et al., 2010). The GOJE was essentially a submarine LIP, with local minor subaerial eruptions (e.g., Mahoney et al., 2001).

Geochronology of the uppermost igneous crust of the Kerguelen Plateau suggests that its older southern portion (the SKP) formed over a prolonged period, with a major peak in magmatic output from ca. 119 to ca. $110 \mathrm{Ma}$ (Coffin et al., 2002; Duncan, 2002; Frey et al., 2003) and 3 distinct ages at 119-118 Ma (ODP Site 1136), ca. $112 \mathrm{Ma}$ (ODP Site 750), and ca. $110 \mathrm{Ma}$ (ODP Site 749) (Frey et al., 2003). Based on the characteristics of the lava flows and of overlying sediments, large parts of the SKP erupted subaerially (Coffin et al., 2002; Frey et al., 2003), although the very first magmatic phase of SKP ca. 119-118 Ma was submarine (Duncan, 2002).

We note that these radiometric dates have large associated uncertainties: \pm 1.8 m.y. in the average ages reported by Chambers et al. (2004) and \pm 1.6 m.y. in the average ages of Timm et al. (2011). A consequence is that the main plateau-building phase of the OJP may have lasted much less than the 124120 Ma interval defined earlier; a substantial portion of this 

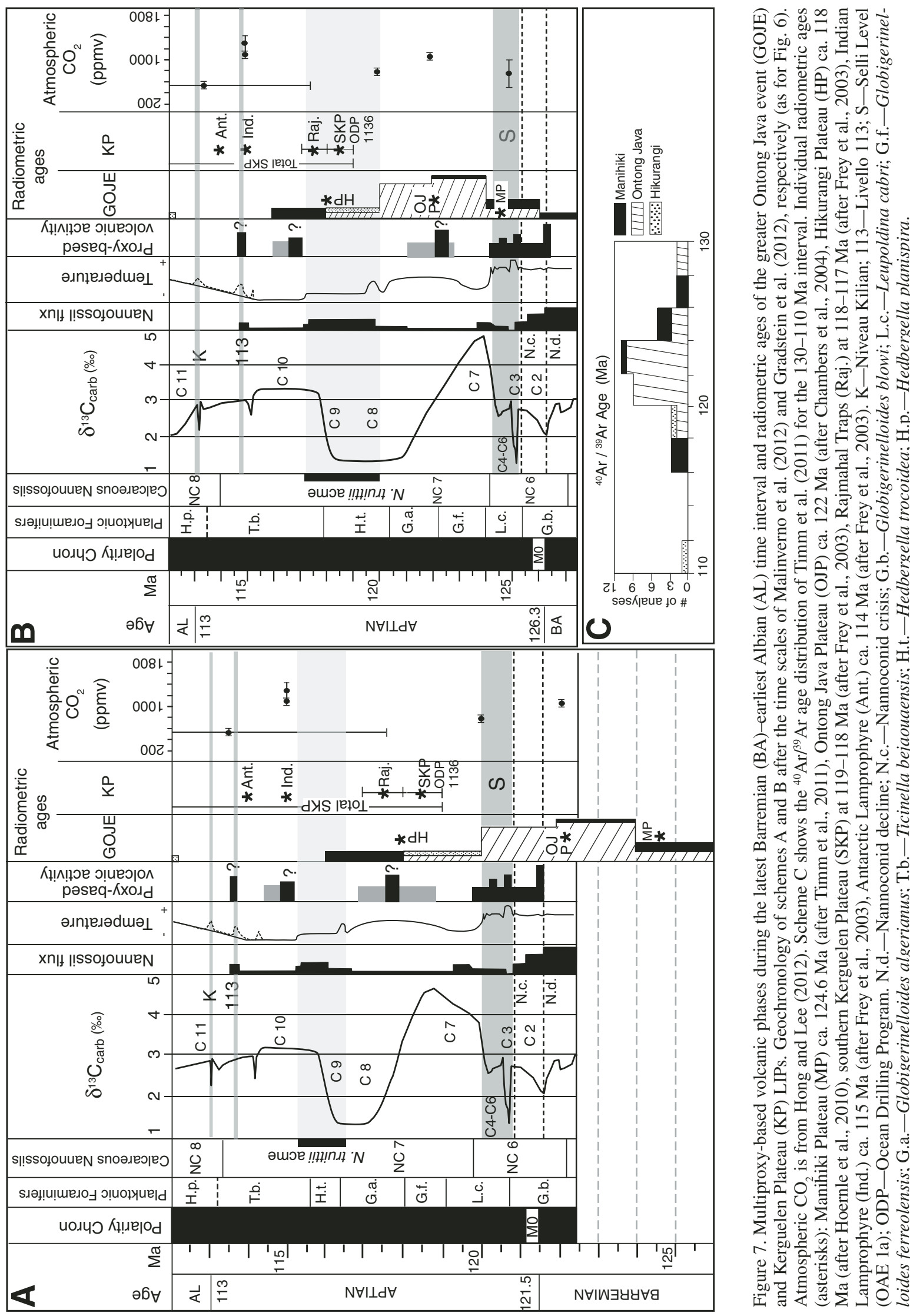
apparent 4 m.y. duration could simply be due to the intrinsic uncertainties of radiometric dating. Absolute ages in available time scales also have uncertainties that are at least 0.5 m.y. (Hinnov and Ogg, 2007; Malinverno et al., 2012). These uncertainties need to be taken into account when comparing ages of events.

Figure 7 plots radiometric ages of GOJE and Kerguelen Plateau LIPs against chronostratigraphic ages of major paleoenvironmental changes using two time scales available for the Aptian (Malinverno et al., 2012; Gradstein et al., 2012). In the Malinverno et al. (2012) time scale, paleoceanographic events in the C2-C6 isotopic segments take place ca. 121.5-120 Ma, which is at the younger end of the 124-120 Ma interval encompassing most of the OJP construction. However, using the Gradstein et al. (2012) time scale, paleoenvironmental perturbations in the latest Barremian-early Aptian interval take place before rather than after the 124-120 Ma interval of OJP volcanism, and increased carbonate production in the late Aptian ( $N$. truittii acme) counterintuitively correlates with a major magmatic phase of the Kerguelen LIP. The Gradstein et al. (2012) time scale essentially implies that there cannot be a causal connection between LIP volcanism and the major paleoenvironmental changes observed in the Aptian. In spite of the dating uncertainties, there is a broad temporal consistency between the dates of OJP volcanism and latest Barremian-early Aptian paleoenvironmental perturbations with the Malinverno et al. (2012) time scale, which is also consistent with the Re-Os age of 120.4 \pm 3.4 Ma for the base of the Selli Level obtained by Bottini et al. (2012). On the contrary, in the Gradstein et al. (2012) time scale the entire Selli Level is older than $124 \mathrm{Ma}$ (Fig. 7).

Establishing a more detailed correlation will require more precise radiometric dates and further revision of available time scales. One of the outstanding issues is the problematic duration of the Aptian stage. Huang et al. (2010) estimated total duration of the Aptian using Milankovitch cycles determined on lithological changes in the Piobbico core; their results significantly revise the durations previously obtained by Herbert et al. (1995) on the same lithostratigraphic interval (units 11-19 of the Piobbico core as defined by Erba, 1988). A puzzling implication of the orbital chronology determined by Huang et al. (2010) is the very low sedimentation rates of the upper Aptian calcareous interval of the Piobbico core. In particular, the sedimentation rates of the $N$. truittii acme interval seem unrealistically low given that the coeval nannoplankton carbonate production increased considerably. Although we recognize the relevance of the work by Huang et al. (2010), it seems urgent to undertake independent evaluation of the astrochronology-based duration of the Aptian, possibly using independent methods (e.g., Meyers and Sageman, 2007; Malinverno et al., 2010) on sequences deposited in different sedimentary basins.

\section{CONCLUSIONS AND PERSPECTIVES}

The Aptian was a time of major perturbations of the oceanatmosphere system, with the onset of greenhouse or supergreen- house conditions followed by general prolonged cooling, and profound changes in chemistry of the surface- and deep-water masses, triggering differential responses of biota. Biocalcification crises and success in pelagic and neritic ecosystems appear to be broadly correlative with, but not necessarily synchronous with, geochemical anomalies. The $\delta^{13} \mathrm{C}$ curve is characterized globally by a complex anomaly (a negative spike preceding an $\sim 2 \%$ o positive excursion) in the early Aptian, followed by a second positive excursion in the late Aptian. The GOJE formed over a 3-5 m.y. interval, with a paroxysmal phase at 125-121 Ma, broadly coincident with OAE $1 \mathrm{a}$ and a widespread drop in relative amount of biogenic carbonate in sediments, associated with excess volcanogenic $\mathrm{CO}_{2}$, extreme warming, and ocean acidification. Causal links between the emplacement of the OJP and the environmental perturbations of the OAE 1a interval can be convincingly made by integrating multiple paleontological, sedimentological, geochemical, and geochronologic data sets. After the most significant events in the early Aptian, other biotic and geochemical changes are documented in the late Aptian, although the lithological expressions are subtle and there is an absence of anoxic conditions on a large scale: this was the time of major magmatism of the SKP and of late phases of the GOJE.

Submarine LIP magmatism (judging from the well-exposed and studied continental counterparts) must have discharged enormous amounts of volatiles during single eruptions, and/or volatiles and major, minor, and trace elements both through magmatic degassing and hydrothermal water-rock exchange. Huge quantities of greenhouse gases and massive release of metals must have had an impact on climatic conditions and chemistry of the oceans, including the carbonate saturation state and trophic levels that directed the temporary dominance of bacterial versus algal phytoplankton. Ash dispersal from subaerial eruptions (SKP) might have even fertilized the oceans directly by greatly increasing the supply of nutrients such as P and Fe (Anbar and Knoll, 2002), stimulating specific marine phytoplankton that reduced atmospheric $\mathrm{CO}_{2}$ by accelerated photosynthetic processes and increased burial rates of organic matter.

The exceptionally massive outpouring of basalts during emplacement of LIPs introduced excess $\mathrm{CO}_{2}$ in the oceanatmosphere system; the almost exclusively submarine GOJE triggered greenhouse or supergreenhouse conditions, whereas extrusion of the subaerial Kerguelen LIP was associated with prolonged cooling, indicating that, in a global context, weathering processes must have been relatively more important than $\mathrm{CO}_{2}$ induced warming. Climate variability is evident through OAE 1a, with at least two relative cooling episodes, perhaps caused by accelerated weathering and/or enhanced burial of organic matter, both resulting in severe $\mathrm{CO}_{2}$ drawdown.

Global anoxia was reached only when intense warming diminished $\mathrm{O}_{2}$ absorption in the ocean and changed circulation patterns; concomitant fertilization (nutrients recycled through accelerated weathering and runoff, and biolimiting metals released by hydrothermal plumes and in volcanic ash) triggered surplus primary productivity with subsequent consumption 
$\mathrm{O}_{2}$ through oxidation of organic matter. In addition, release of reduced metals contributed to near-source oxygen depletion. Under generally cool conditions, the oceans remained well oxygenated even at times of intensified fertility, presumably because cold waters can absorb higher $\mathrm{O}_{2}$ concentrations and (thermohaline) circulation is more vigorous.

Exceptionally high mean $\mathrm{CO}_{2}$ concentrations (3-6 times higher than today) were deleterious to the marine carbonate system regardless of climatic conditions, with evidence of calcification crises and CCD shoaling under either warm or cold climates. Thus climate changes, even when extreme, seem not to have been decisive for biocalcification. Conversely, calcareous nannoplankton and shallow-water calcifiers encountered major difficulties in acidified oceans when volcanogenic $\mathrm{CO}_{2}$ reached extreme concentrations. LIP-derived biolimiting and/or toxic metals possibly further stressed the oceanic biota, which was forced to adapt and survive under eutrophic conditions and/or selectively toxic waters.

The most striking paleoenvironmental perturbation is OAE 1a, but several signs of change such as the nannoconid decline, the onset of the nannoplankton speciation, and the first major peak in metal enrichment, preceded global anoxia by $\sim 1$ m.y. Are these environmental changes just before magnetochron CM0 the evidence of onset of OJP volcanism? Were these latest Barremian perturbations related to the Manihiki Plateau emplacement? Was global anoxia reached only when threshold conditions were overtaken? Was accidental co-occurrence of multiple triggering events, after preconditioning of the oceans, the ultimate stimulus for a paleoenvironmental crash?

Future work on major, minor, and trace elements as well as $\mathrm{Os}$ and $\mathrm{Pb}$ isotopes might further identify the source area of release and time frame of magmatism. Highly resolved variations in metal concentrations at near-source locations would reveal eruption rates of outpouring lavas, which will be crucial for estimating the relative importance of LIP volcanism and its individual phases. Furthermore, evaluation of volatile outputs and their release rates would greatly improve our understanding of ecosystem changes in response to major magmatic events.

We stress the importance of improved chronology for both sedimentary sequences and LIP volcanism. This need is underscored by conflicting available Aptian time scales. One time scale implies that the GOJE LIP volcanism took place after the environmental perturbations in the sedimentary record (Gradstein et al., 2012), meaning that there could be no cause and effect relationship. We favor the time scale of Malinverno et al. (2012) that makes volcanism occur before its inferred environmental consequences and is consistent with the absolute age of magnetochron CM0 (He et al., 2008) and the Re-Os age of the base of the Selli Level (Bottini et al., 2012).

We emphasize the fact that the environmental disruptions caused by the GOJE did not trigger extinctions. On the contrary, a major evolutionary radiation of calcareous nannoplankton was perhaps the strategic response to adverse surface-water chemistry. The rock-forming nannoconids underwent a major temporary decline during OAE 1a but survived, presumably in sufficiently protected ecological niches, to flourish when paroxysmal OJP volcanism ended. Likewise, the carbonate-producing rudists underwent a severe crisis during OAE 1a, and their subsequent partial recovery was marked by calcite-dominated forms and the failure of most aragonitic taxa.

The annihilation of most nannoconids and extinction of many nannoplankton and planktonic foraminiferal taxa occurred in late-late Aptian time, when the SKP formed. Perhaps prolonged conditions of cool or cold surface waters promoted ocean acidification that severely affected and killed most of the heavily calcified and long-ranging (stable) taxa.

\section{ACKNOWLEDGMENTS}

We gratefully acknowledge constructive criticism provided by two anonymous reviewers and Clive Neal. Erba, Bottini, and Tiraboschi were funded through MIUR-PRIN 2011(Ministero dell'Istruzione, dell'Università e della Ricerca-Progetti di Ricerca di Interesse Nazionale). Duncan acknowledges funding by the Petroleum Research Fund of the American Chemical Society and the Distinguished Scientist Fellowship Program, King Saud University. Weissert acknowledges funding by the Swiss Science Foundation. Malinverno acknowledges funding by U.S. National Science Foundation grant OCE 09-26306. Samples from Deep Sea Drilling Project Sites 167 and 463 and Ocean Drilling Program Site 866 were supplied by the Integrated Ocean Drilling Program.

\section{REFERENCES CITED}

Aguado, R., Company, M., Sandoval, J., and Tavera, J.M., 1997, Biostratigraphic events at the Barremian-Aptian boundary in the Betic Cordillera (southern Spain): Cretaceous Research, v. 18, p. 309-329, doi:10.1006/ cres.1997.0069.

Aguado, R., Castro, J.M., Company, M., and De Gea, G.A., 1999, Aptian bioevents-An integrated biostratigraphic analysis of the Almadich formation, inner Prebetic Domain, SE Spain: Cretaceous Research, v. 20, p. 663-683, doi:10.1006/cres.1999.0176.

Anbar, A.D., and Knoll, A.H., 2002, Proterozoic ocean chemistry and evolution: A bioinorganic bridge?: Science, v. 297, p. 1137-1142, doi:10.1126/ science. 1069651.

Ando, A., Kakegawa, T., Takashima, R., and Saito, T., 2002, New perspective on Aptian carbon isotope stratigraphy: Data from $\delta^{13} \mathrm{C}$ records of terrestrial organic matter: Geology, v. 30, p. 227-230, doi:10.1130/0091-7613 (2002)030<0227:NPOACI >2.0.CO;2.

Ando, A., Kakegawa, T., Takashima, R., and Saito, T., 2003, Stratigraphic carbon isotope fluctuations of detrital woody materials during the Aptian Stage in Hokkaido, Japan: Comprehensive $\delta^{13} \mathrm{C}$ data from four sections of the Ashibetsu area: Journal of Asian Earth Sciences, v. 21, p. 835-847, doi:10.1016/S1367-9120(02)00112-8.

Ando, A., Kaiho, K., Kawahata, H., and Kakegawa, T., 2008, Timing and magnitude of early Aptian extreme warming: Unraveling primary $\delta^{18} \mathrm{O}$ variation in indurated pelagic carbonates at Deep Sea Drilling Project Site 463, central Pacific Ocean: Palaeogeography, Palaeoclimatology, Palaeoecology, v. 260, p. 463-476, doi:10.1016/j.palaeo.2007.12.007.

Bachmann, M., and Hirsch, F., 2006, Lower Cretaceous carbonate platform of the eastern Levant (Galilee and the Golan Heights): Stratigraphy and second-order sea-level change: Cretaceous Research, v. 27, p. 487-512, doi:10.1016/j.cretres.2005.09.003.

Baudin, F., Fiet, N., Coccioni, R., and Galeotti, S., 1998, Organic matter characterisation of the Selli Level (Umbria-Marche Basin, central Italy): Cretaceous Research, v. 19, p. 701-714, doi:10.1006/cres.1998.0126 
Beerling, D.J., Lomas, M.R., and Gröcke, D.R., 2002, On the nature of methane gas-hydrate dissociation during the Toarcian and Aptian Oceanic Anoxic Events: American Journal of Science, v. 302, p. 28-49, doi:10.2475/ ajs.302.1.28.

Bellanca, A., Erba, E., Neri, R., Premoli Silva, I., Sprovieri, M., Tremolada, F., and Verga, D., 2002, Paleoceanographic significance of the Tethyan "Livello Selli" (early Aptian) from the Hybla Formation, northwestern Sicily: Biostratigraphy and high-resolution chemostratigraphic records: Palaeogeography, Palaeoclimatology, Palaeoecology, v. 185, p. 175-196, doi:10.1016/S0031-0182(02)00299-7.

Berner, R.A., and Beerling, D.J., 2007, Volcanic degassing necessary to produce a $\mathrm{CaCO}_{3}$ undersaturated ocean at the Triassic-Jurassic boundary: Palaeogeography, Palaeoclimatology, Palaeoecology, v. 244, p. 368-373, doi:10.1016/j.palaeo.2006.06.039.

Bersezio, R., 1993, Sedimentary events and rhythms in an Early Cretaceous pelagic environment: The Maiolica Formation of the Lombardy Basin (Southern Alps): Giornale di Geologia, v. 55, no. 1, p. 5-20.

Bersezio, R., 1994, Stratigraphic framework and sedimentary features of the lower Aptian "Livello Selli" in the Lombardy Basin (Southern Alps, Northern Italy): Rivista Italiana di Paleontologia e Stratigrafia, v. 99, p. 569-590.

Bersezio, R., Erba, E., Gorza, M., and Riva, A., 2002, Berriasian-Aptian black shales of the Maiolica Formation (Lombardian Basin, Southern Alps, northern Italy): Local to global events: Palaeogeography, Palaeoclimatology, Palaeoecology, v. 180, p. 253-275, doi:10.1016/S0031 -0182(01)00416-3.

Bischoff, G., and Mutterlose, J., 1998, Calcareous nannofossils of the Barremian/Aptian boundary interval in NW Europe: Biostratigraphic and palaeoecologic implications of a high resolution study: Cretaceous Research, v. 19, p. 635-661, doi:10.1006/cres.1998.0123.

Blättler, C.L., Jenkyns, H.C., Reynard, L.M., and Handerson, G.M., 2011, Significant increases in global weathering during Oceanic Anoxic Events 1a and 2 indicated by calcium isotopes: Earth and Planetary Science Letters, v. 309, p. 77-88, doi:10.1016/j.epsl.2011.06.029.

Bodin, S., Godet, A., Westermann, S., and Föllmi, K.B., 2013, Secular change in north western Tethyan water-mass oxygenation during the late Hauterivian-early Aptian: Earth and Planetary Science Letters, v. 374, p. 121-131, doi:10.1016/j.epsl.2013.05.030.

Bottini, C., and Mutterlose, J., 2012, Integrated stratigraphy of early Aptian black shales in the Boreal Realm: Calcareous nannofossil and stable isotope evidence for global and regional processes: Newsletters On Stratigraphy, v. 45, p. 115-137, doi:10.1127/0078-0421/2012/0017.

Bottini, C., Cohen, A.S., Erba, E., Jenkyns, H.C., and Coe, A.L., 2012, Osmium isotope evidence for volcanism, weathering and ocean mixing during the early Aptian OAE 1a: Geology, v. 40, p. 583-586, doi:10.1130/G33140.1.

Bottini, C., Erba, E., Tiraboschi, D., Jenkyns, H.C., Schouten, S., and Sinninghe Damsté, J.S., 2014, Climate variability and relationship with ocean fertility during the Aptian Stage: Climate of the Past Discussion, v. 10, p. 689738, doi:10.5194/cpd-10-689-2014.

Bottini, C., Erba, E., Tiraboschi, D., Jenkyns, H.C., Schouten, S., and Sinninghe Damsté, J.S., 2015, Climate variability and ocean fertility during the Aptian Stage: Climate of the Past, v. 11, 1-22, doi:10.5194/cp-11-1-2015.

Bover-Arnal, T., Moreno-Bedmar, J.A., Salas, R., Skelton, P.W., Bitzer, K., and Gili, E., 2010, Sedimentary evolution of an Aptian syn-rift carbonate system (Maestrat Basin, E Spain): Effects of accommodation and environmental change: Geologica Acta, v. 8, p. 249-280, doi:10.1344/105.000001533.

Bover-Arnal, T., Salas, R., Martin-Closas, C., Schlagintweit, F., and MorenoBedmar, J.A., 2011, Expression of an Oceanic Anoxic Event in a neritic setting: Lower Aptian coral rubble deposits from the western Maestrat Basin (Iberian Chain, Spain): Palaios, v. 26, p. 18-32, doi:10.2110/ palo.2010.p10-055r.

Bown, P.R., Lees, J.A., and Young, J.R., 2004, Calcareous nannoplankton evolution and diversity through time, in Thierstein, H.R., and Young, J.R., eds., Coccolithophores: From Molecular Processes to Global Impact: Berlin, Springer-Verlag, p. 481-508.

Bralower, T.J., Sliter, W.V., Arthur, M.A., Leckie, R.M., Allard, D.J., and Schlanger, S.O., 1993, Dysoxic/anoxic episodes in the Aptian-Albian (Early Cretaceous), in Pringle, M., Sager, W.W., Sliter, W.V., and Stein, S., eds., The Mesozoic Pacific: Geology, Tectonics and Volcanism: American Geophysical Union Geophysical Monograph 77, p. 5-37, doi:10.1029/ GM077p0005.
Bralower, T.J., Arthur, M.A., Leckie, R.M., Sliter, W.V., Allard, D.J., and Schlanger, S.O., 1994, Timing and paleoceanography of oceanic dysoxia/ anoxia in the late Barremian to early Aptian: Palaios, v. 9, p. 335-369, doi: $10.2307 / 3515055$

Bralower, T.J., Fullagar, P.D., Paull, C.K., Dwyer, G.S., and Leckie, R.M., 1997, Mid-Cretaceous strontium-isotope stratigraphy of deep-sea sections: Geological Society of America Bulletin, v. 109, p. 1421-1442, doi:10.1130/0016-7606(1997)109<1421:MCSISO>2.3.CO;2.

Bralower, T.J., Cobabe, E., Clement, B., Sliter, W.V., Osburne, C., and Longoria, J., 1999, The record of global change in mid-Cretaceous, BarremianAlbian sections from the Sierra Madre, northeastern Mexico: Journal of Foraminiferal Research, v. 29, p. 418-437.

Bréhéret, J.G., 1997, L'Aptien et l'Albien de la Fosse Vocontienne (des bordures au bassin). Evolution de la sédimentation et enseignemnts sur les événements anoxiques: Société Géologique du Nord Publication 25, 614 p.

Burchette, T.P., and Wright, V.P., 1992, Carbonate ramp depositional systems: Sedimentary Geology, v. 79, p. 3-57, doi:10.1016/0037-0738(92)90003-A

Burla, S., Heimhofer, U., Hochuli, P.A., Weissert, H., and Skelton, P., 2008 , Changes in sedimentary patterns of coastal and deep-sea successions from the North Atlantic (Portugal) linked to Early Cretaceous environmental change: Palaeogeography, Palaeoclimatology, Palaeoecology, v. 257, p. 38-57, doi:10.1016/j.palaeo.2007.09.010.

Burla, S., Oberli, F., Heimhofer, U., Wiechert, U., and Weissert, H., 2009, Improved time control on Cretaceous coastal deposits: New results from $\mathrm{Sr}$ isotope measurements using laser ablation: Terra Nova, v. 21, p. 401409, doi:10.1111/j.1365-3121.2009.00897.x.

Chambers, L.M., Pringle, M.S., and Fitton, J.G., 2004, Phreatomagmatic eruptions on the Ontong Java Plateau: An Aptian ${ }^{40} \mathrm{Ar} /{ }^{39} \mathrm{Ar}$ age for volcaniclastic rocks at ODP Site 1184, in Fitton, J.G., Mahoney, J.J., Wallace, P.J., and Saunders, A.D., eds., Origin and Evolution of the Ontong Java Plateau: Geological Society of London Special Publication 229, p. 325-331, doi:10.1144/GSL.SP.2004.229.01.18.

Chandler, M.T., Wessel, P., Taylor, B., Seton, M., Kim, S.S., and Hyeong, K., 2012, Reconstructing Ontong Java Nui: Implications for Pacific absolute plate motion, hotspot drift and true polar wander: Earth and Planetary Science Letters, v. 331, p. 140-151, doi:10.1016/j.eps1.2012.03.017.

Channell, J.E.T., Lowrie, W., and Medizza, F., 1979, Middle and Early Cretaceous magnetic stratigraphy from the Cismon section, northern Italy: Earth and Planetary Science Letters, v. 42, p. 153-166, doi:10.1016/0012 $-821 X(79) 90021-9$

Channell, J.E.T., Erba, E., Nakanishi, M., and Tamaki, K., 1995, Late JurassicEarly Cretaceous time scales and oceanic magnetic anomaly block models, in Berggren, W.A., ed., Geochronology, Time Scales, and Stratigraphic Correlation: SEPM (Society for Sedimentary Geology) Special Publication 54, p. 51-63.

Channell, J.E.T., Erba, E., Muttoni, G., and Tremolada, F., 2000, Early Cretaceous magnetic stratigraphy in the APTICORE drill core and adjacent outcrop at Cismon (Southern Alps, Italy), and the correlation to the proposed Barremian/Aptian boundary stratotype: Geological Society of America Bulletin, v. 112, p. 1430-1443, doi:10.1130/0016 -7606(2000)112<1430:ECMSIT>2.0.CO;2.

Cobianchi, M., Luciani, V., and Menegatti, A., 1999, The Selli level of the Gargano Promontory, Apulia, southern Italy: Foraminiferal and calcareous nannofossil data: Cretaceous Research, v. 20, p. 255-269, doi:10.1006/ cres.1999.0155.

Coccioni, R., Nesci, O., Tramontana, M., Wezel, C.F., and Moretti, E., 1987, Descrizione di un livello-guida "Radiolaritico-Bituminoso-Ittiolitico" alla base delle Marne a Fucoidi nell' Appennino Umbro-Marchigiano: Bollettino della Società Geologica Italiana, v. 106, p. 183-192.

Coccioni, R., Franchi, R., Nesci, O., Wezel, C.F., Battistini, F., and Pallecchi, P., 1989, Stratigraphy and mineralogy of the Selli level (early Aptian) at the base of the Marne a Fucoidi in the Umbrian-Marchean Apennines (Italy), in Wiedmann, J., ed., Cretaceous of Western Tethys: 3rd International Cretaceous Symposium: Stuttgart, Germany, Schweizerbartsche, p. $563-584$.

Coccioni, R., Erba, E., and Premoli Silva, I., 1992, Barremian-Aptian calcareous plankton biostratigraphy from the Gorgo a Cerbara section (Marche, Central Italy) and implication for planktonic evolution: Cretaceous Research, v. 13, p. 517-537, doi:10.1016/0195-6671(92)90015-I.

Coccioni, R., Luciani, V., and Marsili, A., 2006, Cretaceous oceanic anoxic events and radially elongated chambered planktonic foraminifera: Paleoecological and paleoceanographic implications: Palaeogeography, 
Palaeoclimatology, Palaeoecology, v. 235, p. 66-92, doi:10.1016/j.palaeo .2005 .09 .024 .

Coffin, M.F., and Eldholm, O., eds., 1991, Large igneous provinces: JOI/ USSAC workshop report: University of Texas Institute for Geophysics Technical Report 114, 79 p.

Coffin, M.F., and Eldholm, O., 1994, Large igneous provinces: Crustal structure, dimensions, and external consequences: Reviews of Geophysics, v. 32, p. 1-36, doi:10.1029/93RG02508

Coffin, M.F., Pringle, M.S., Duncan, R.A., Gladczenko, T.P., Storey, M., Müller, R.D., and Gahagan, L.A., 2002, Kerguelen hotspot magma output since 130 Ma: Journal of Petrology, v. 43, p. 1121-1137, doi:10.1093/ petrology/43.7.1121.

Da Gama, R.B.P., Bown, P.R., and Cabral, M.C., 2009, Calcareous nannofossil biostratigraphy of an outcrop section of Aptian sediments of westcentral Portugal (Lusitanian Basin): Journal of Micropalaeontology, v. 28, p. 153-160, doi:10.1144/jm.28.2.153.

Danelian, T., Tsikos, H., Gardin, S., Baudin, F., Bellier, J.P., and Emmanuel, L., 2004, Global and regional palaeoceanographic changes as recorded in the mid-Cretaceous (Aptian-Albian) sequence of the Ionian zone (NW Greece): Geological Society of London Journal, v. 161, p. 703-709, doi:10.1144/0016-764903-088.

de Gea, G.A., Aguado, R., Castro, J.M., Molina, J.M., O'Dogherty, L., and Ruiz-Ortiz, P.A., 2008, Lower Aptian Subbetic organic-rich facies, radiolarites, and associated deposits: The local expression of Oceanic Anoxic Event 1a (Carbonero Formation, southern Spain): Cretaceous Research, v. 29, p. 861-870, doi:10.1016/j.cretres.2008.05.011.

De Lurio, J.L., and Frakes, L.A., 1999, Glendonites as a palaeoenvironmental tool: Implications for Early Cretaceous high latitude climates in Australia: Geochimica et Cosmochimica Acta, v. 63, p. 1039-1048, doi:10.1016/ S0016-7037(99)00019-8.

Di Lucia, M., Trecalli, A., Mutti, M., and Parente, M., 2012, Bio-chemostratigraphy of the Barremian-Aptian shallow-water carbonates of the southern Apennines (Italy): Pinpointing the OAE1a in a Tethyan carbonate platform: Solid Earth, v. 3, p. 1-28, doi:10.5194/se-3-1-2012.

Dumitrescu, M., and Brassell, S.C., 2005, Biogeochemical assessment of sources of organic matter and paleoproductivity during the early Aptian Oceanic Anoxic Event at Shatsky Rise, ODP Leg 198: Organic Geochemistry, v. 36, p. 1002-1022, doi:10.1016/j.orggeochem.2005.03.001.

Dumitrescu, M., and Brassell, S.C., 2006, Compositional and isotopic characteristics of organic matter for the early Aptian oceanic anoxic event at Shatsky Rise, ODP leg 198: Palaeogeography, Palaeoclimatology, Palaeoecology, v. 235, p. 168-191, doi:10.1016/j.palaeo.2005.09.028.

Dumitrescu, M., Brassell, S.C., Schouten, S., Hopmans, E.C., and Sinninghe Damsté, J.S., 2006, Instability in tropical Pacific sea-surface temperatures during the early Aptian: Geology, v. 34, p. 833-866, doi:10.1130/ G22882.1.

Duncan, R.A., 2002, A time for construction of the Kerguelen Plateau and Broken Ridge: Journal of Petrology, v. 43, p. 1109-1119, doi:10.1093/ petrology/43.7.1109.

Duncan, R.A., Tiraboschi, D., Erba, E., Walczak, P., and Clarke, L.J., 2007, The Cretaceous OAE1a-submarine plateau link: Additional geochemical evidence from marine sedimentary sections: Eos (Transactions, American Geophysical Union), v. 89, p. T13A-1125.

Eldholm, O., and Coffin, M.F., 2000, Large igneous provinces and plate tectonics, in Richards, M., Gordon, R., and van der Hilst, R., eds., The History and Dynamics of Global Plate Motion: American Geophysical Union Geophysical Monograph 121, p. 309-326, doi:10.1029/GM121p0309.

Elkhazri, A., Razgallah, S., Abdallah, H., and Ben Haj Ali, N., 2009, L'événement anoxique OAE 1a Barrémo-Aptien en Tunisie nordorientale: Intérêt des foraminifères: Revue de Paléobiologie, v. 28, p. 93-130.

Erba, E., 1988, Aptian-Albian calcareous nannofossil biostratigraphy of the Scisti a Fucoidi cored at Piobbico (central Italy): Rivista Italiana di Paleontologia e Stratigrafia, v. 94, p. 249-284.

Erba, E., 1994, Nannofossils and superplumes: The early Aptian 'nannoconid crisis': Paleoceanography, v. 9, p. 483-501, doi:10.1029/94PA00258.

Erba, E., 1996, The Aptian Stage, in Rawson, P.F., Dhondt, A.V., Hancock, J.M., and Kennedy, W.J., eds., Proceedings of the 2nd International Symposium on Cretaceous Stage Boundaries: Bulletin de l'Institut Royal des Sciences Naturelles de Belgique, v. 66, supplement, p. 31-43.

Erba, E., 2004, Calcareous nannofossils and Mesozoic oceanic anoxic events: Marine Micropaleontology, v. 52, p. 85-106, doi:10.1016/j .marmicro.2004.04.007.
Erba, E., 2006, The first 150 million years history of calcareous nannoplankton: Biosphere-geosphere interactions: Palaeogeography, Palaeoclimatology, Palaeoecology, v. 232, p. 237-250, doi:10.1016/j.palaeo.2005.09.013.

Erba, E., and Larson, R., 1998, The Cismon Apticore (Southern Alps, Italy): "Reference section" for the Lower Cretaceous at low latitudes: Rivista Italiana di Paleontologia e Stratigrafia, v. 104, p. 181-192.

Erba, E., and Quadrio, B., 1987, Biostratigrafia a Nannofossili calcarei, Calpionellidi e Foraminiferi planctonici della Maiolica (Titoniano superioreAptiano) nelle Prealpi Bresciane (Italia settentrionale): Rivista Italiana di Paleontologia e Stratigrafia, v. 93, p. 3-108.

Erba, E., and Tremolada, F., 2004, Nannofossil carbonate fluxes during the Early Cretaceous: phytoplankton response to nutrification episodes, atmospheric $\mathrm{CO}_{2}$ and anoxia: Paleoceanography, v. 19, p. 1-18, doi:10.1029/2003PA000884.

Erba, E., Coccioni, R., and Premoli Silva, I., 1989, Gli Scisti a Fucoidi nell'area umbro-marchigiana: le sezioni della S.S. Apecchiese, in Cresta, S., Monechi, S., and Parisi, G., eds., Stratigrafia del Mesozoico e Cenozoico nell' area umbro-marchigiana. Itinerari geologici sull'Appennino umbromarchigiano (Italia): Memorie Descrittive della Carta Geologica d'Italia 39: Roma, Istituto Poligrafico e Zecca dello Stato, p. 146-164.

Erba, E., Channell, J.E.T., Claps, M., Jones, C., Larson, R.L., Opdyke, B., Premoli Silva, I., Riva, A., Salvini, G., and Torricelli, S., 1999, Integrated stratigraphy of the Cismon Apticore (Southern Alps, Italy): A "reference section" for the Barremian-Aptian interval at low latitudes: Journal of Foraminiferal Research, v. 29, p. 371-391.

Erba, E., Bottini, C., Weissert, J.H., and Keller, C.E., 2010, Calcareous nannoplankton response to surface-water acidification around Oceanic Anoxic Event 1a: Science, v. 329, p. 428-432, doi:10.1126/science.1188886.

Erbacher, J., and Thurow, J., 1997, Influence of oceanic anoxic events on the evolution of mid-Cretaceous radiolaria in the North Atlantic and western Tethys: Marine Micropaleontology, v. 30, p. 139-158, doi:10.1016/ S0377-8398(96)00023-0.

Erbacher, J., Thurow, J., and Littke, R., 1996, Evolution patterns of radiolarian and organic matter variations: A new approach to identify sea-level changes in mid-Cretaceous pelagic environments: Geology, v. 24, p. 499502, doi:10.1130/0091-7613(1996)024<0499:EPORAO > 2.3.CO;2.

Ferreri, V., Weissert, H., D'Argenio, B., and Buonocunto, F.P., 1997, Carbon isotope stratigraphy: A tool for basin to carbonate platform correlation: Terra Nova, v. 9, p. 57-61, doi:10.1111/j.1365-3121.1997.tb00002.x.

Fiet, N., and Gorin, G., 2000, Lithological expression of Milankovitch cyclicity in carbonate-dominated, pelagic, Barremian deposits in central Italy: Cretaceous Research, v. 21, p. 457-467, doi:10.1006/cres.2000.0220.

Föllmi, K.B., 2008, A synchronous, middle early Aptian age for the demise of the Helvetic Urgonian platform related to the unfolding oceanic anoxic event 1a ("Selli event"): Revue de Paléobiologie, v. 27, p. 461-468.

Föllmi, K.B., 2012, Early Cretaceous life, climate and anoxia: Cretaceous Research, v. 35, p. 230-257, doi:10.1016/j.cretres.2011.12.005.

Föllmi, K.B., and Gainon, F., 2008, Demise of the northern Tethyan Urgonian carbonate platform and subsequent transition towards pelagic conditions: The sedimentary record of the Col de la Plaine Morte area, central Switzerland: Sedimentary Geology, v. 205, p. 142-159, doi:10.1016/j.sedgeo.2008.02.005.

Föllmi, K.B., Weissert, H., Bisping, M., and Funk, P., 1994, Phosphogenesis, carbon-isotope stratigraphy and carbonate-platform evolution along the Lower Cretaceous northern Tethyan margin: Geological Society of America Bulletin, v. 106, p. 729-746, doi:10.1130/0016 -7606(1994)106<0729:PCISAC >2.3.CO;2.

Föllmi, K.B., Godet, A., Bodin, S., and Linder, P., 2006, Interactions between environmental change and shallow water carbonate buildup along the northern Tethyan margin and their impact on the Early Cretaceous carbon isotope record: Paleoceanography, v. 21, PA4211, doi:10.1029/2006PA001313.

Frakes, L.A., and Francis, J.E., 1988, A guide to Phanerozoic cold polar climates from high-latitude ice-rafting in the Cretaceous: Nature, v. 333, p. 547-549, doi: $10.1038 / 333547 \mathrm{a} 0$.

Frey, F.A., Coffin, M.F., Wallace, P.J., and Quilty, P.J., 2003, Proceedings of the Ocean Drilling Program, Scientific Results, Volume 183: College Station, Texas, Ocean Drilling Program, doi:10.2973/odp.proc.sr.183.2003.

Gaida, K.H., Gedenk, R., Kemper, E., Michaelis, W., Scheuch, R., Schmitz, H.H., and Zimmerle, W., 1981, Lithologische, mineralogische und organisch-geochemische Untersucngen an Tonsteinen und Tonmergelsteinen der Unterkreide Nordwestdeutschlands: Geologisches Jahrbuch, Reihe A, v. 58, p. 15-47 
Gaona-Narvaez, T., Maurrasse, F.J.-M.R., and Moreno-Bedmar, J.A., 2013, Stable carbon-isotope stratigraphy and ammonite biochronology at Madotz, Navarra, northern Spain: Implications for the timing and duration of oxygen depletion during OAE-1a: Cretaceous Research, v. 40, p. 143-157, doi:10.1016/j.cretres.2012.06.005.

Garcia-Mondejar, J., Owen, H.G., Raisossadat, N., Millan, M.I., and Fernandez-Mendiola, P.A., 2009, The early Aptian of Aralar (northern Spain): Stratigraphy, sedimentology, ammonite biozonation, and OAE1: Cretaceous Research, v. 30, p. 434-464, doi:10.1016/j.cretres.2008.08.006.

Gavrilov, Y.O., Shchepetova, E.V., Baraboshkin, E.Y., and Shcherbinina, E.A., 2002, The Early Cretaceous anoxic basin of the Russian Plate: Sedimentology and geochemistry: Lithology and Mineral Resources, v. 37, p. 310-329, doi:10.1023/A:1019943305677.

Gorin, G., Fiet, N., and Pacton, M., 2009, Benthic microbial mats: A possible major component of organic matter accumulation in the lower Aptian oceanic anoxic event: Terra Nova, v. 21, p. 21-27, doi:10.1111/j.1365 $-3121.2008 .00848 . x$

Gradstein, F.M., Ogg, J.G., and Smith, A.G., 2004, The Geologic Time Scale 2004: Cambridge, UK, Cambridge University Press, 640 p.

Gradstein, F.M., Ogg, J.G., Schmitz, M.D., and Ogg, G.M., 2012, The Geologic Time Scale 2012: Amsterdam, Elsevier B.V., 1176 p.

Graziano, R., 2013, Sedimentology, biostratigraphy and event stratigraphy of the early Aptian Oceanic Anoxic Event (OAE1a) in the Apulia Carbonate Platform Margin-Ionian Basin System (Gargano Promontory, southern Italy): Cretaceous Research, v. 39, p. 78-111, doi:10.1016/j .cretres.2012.05.014.

Gröcke, D.R., Hesselbo, S.P., and Jenkyns, H.C., 1999, Carbon-isotope composition of Lower Cretaceous fossil wood: Ocean-atmosphere chemistry and relation to sea-level change: Geology, v. 27, p. 155-158, doi:10.1130/0091-7613(1999)027<0155:CICOLC >2.3.CO;2.

Grötsch, J., 1993, Guilds, cycles, and episodic vertical aggradation of a reef (late Barremian to early Aptian, Dinaric carbonate platform, Slovenia), in de Boer, P.L., and Smith, D., eds., Orbital Forcing and Cyclic Sequences: International Association of Sedimentologists Special Publication 19, p. 227-242, doi:10.1002/9781444304039.ch17.

Grötsch, J., Billing, I., and Vahrenkamp, V.C., 1998, Carbon-isotope stratigraphy in shallow-water carbonates: Implications for Cretaceous blackshale deposition: Sedimentology, v. 45, p. 623-634, doi:10.1046/j.1365 $-3091.1998 .00158 . x$

Habermann, A., and Mutterlose, J., 1999, Early Aptian black shales from NW Germany: Calcareous nannofossil and their paleoceanographic implications: Neues Jahrbuch für Geologie und Palaontologie Abhandlungen, v. 212 , p. $379-400$.

Hay, W.W., 2009, Cretaceous oceans and ocean modeling, in Hu, X., Wang, C., Scott, R.W., Wagreich, M., and Jansa, L., eds., Cretaceous Oceanic Red Beds: Stratigraphy, Composition, Origins and Paleoceanographic and Paleoclimatic Significance: SEPM (Society for Sedimentary Geology) Special Publication 91, p. 243-271.

He, H., Pan, Y., Tauxe, L., Qin, H., and Zhu, R., 2008, Toward age determination of the M0r (Barremian-Aptian boundary) of the Early Cretaceous: Physics of the Earth and Planetary Interiors, v. 169, p. 41-48, doi:10.1016/j .pepi.2008.07.014.

Heimhofer, U., Hochuli, P.A., Burla, S., Andersen, N., and Weissert, H., 2003, Terrestrial carbon-isotope records from coastal deposits (Algarve, Portugal): A tool for chemostratigraphic correlation on an intrabasinal and global scale: Terra Nova, v. 15, p. 8-13, doi:10.1046/j.1365 $-3121.2003 .00447 . x$.

Heimhofer, U., Hochuli, P.A., Herrle, J.O., Andersen, N., and Weissert, H., 2004, Absence of major vegetation and palaeoatmospheric $p \mathrm{CO}_{2}$ changes associated with oceanic anoxic event 1a (Early Aptian, SE France) Earth and Planetary Science Letters, v. 223, p. 303-318, doi:10.1016/j .eps1.2004.04.037.

Heimhofer, U., Hochuli, P.A., Dinis, J.M.L., and Weissert, H., 2005, Timing of Early Cretaceous angiosperm diversification and possible links to major paleoenvironmental change: Geology, v. 33, p. 141-144, doi:10.1130/G21053.1.

Heimhofer, U., Hochuli, P.A., Herrle, J.O., Andersen, N., and Weissert, H., 2006, Contrasting origins of Early Cretaceous black shales in the Vocontian Basin: Evidence from palynological and calcareous nannofossil records: Palaeogeography, Palaeoclimatology, Palaeoecology, v. 235, p. 93-109, doi:10.1016/j.palaeo.2005.09.025.

Heldt, M., Bachmann, M., and Lehmann, J., 2008, Microfacies, biostratigraphy, and geochemistry of the hemipelagic Barremian-Aptian in north- central Tunisia: Influence of the OAE 1a on the southern Tethys margin: Palaeogeography, Palaeoclimatology, Palaeoecology, v. 261, p. 246-260, doi:10.1016/j.palaeo.2008.01.013.

Heldt, M., Mutterlose, J., Berner, U., and Erbacher, J., 2012, First highresolution $\delta^{13} \mathrm{C}$ records across black shales of the Early Aptian Oceanic Anoxic Event 1a within the mid-latitudes of NW Europe (Germany, Lower Saxony Basin): Newsletters on Stratigraphy, v. 45, p. 151-169, doi:10.1127/0078-0421/2012/0019.

Herbert, T.D., 1992, Paleomagnetic calibration of Milankovitch cyclicity in lower Cretaceous sediments: Earth and Planetary Science Letters, v. 112, p. 15-28, doi:10.1016/0012-821X(92)90003-E.

Herbert, T., Premoli Silva, I., Erba, E., and Fischer, A.G., 1995, Orbital chronology of Cretaceous-Paleocene marine sediments, in Berggren, W.A., Kent, D.V., Aubry, M.P., and Hardenbol, J., eds., Geochronology, Time Scales, and Global Stratigraphic Correlation: SEPM (Society for Sedimentary Geology) Special Publication 54, p. 81-93, doi:10.2110/pec.95.04.0081.

Herrle, J.O., and Mutterlose, J., 2003, Calcareous nannofossils from the Aptian-lower Albian southeast France: Paleoecological and biostratigraphic implication: Cretaceous Research, v. 24, p. 1-22, doi:10.1016/ S0195-6671(03)00023-5.

Herrle, J.O., Kößler, P., Friedrich, O., Erlenkeuser, H., and Hemleben, C., 2004, High resolution carbon isotope records of the Aptian to lower Albian from SE France and the Mazagan Plateau (DSDP Site 545): A stratigraphic tool for paleoceanographic and paleobiologic reconstruction: Earth and Planetary Science Letters, v. 218, p. 149-161, doi:10.1016/S0012 $-821 X(03) 00646-0$.

Herrle, J.O., Kößler, P., and Bollmann, J., 2010, Palaeoceanographic differences of early late Aptian black shale events in the Vocontian Basin (SE France): Palaeogeography, Palaeoclimatology, Palaeoecology, v. 297, p. 367-376, doi:10.1016/j.palaeo.2010.08.015.

Hesselbo, S., Gröcke, D., Jenkyns, H.C., Bjerrum, C.J., Farrimond, P., Morgans Bell, H.S., and Green, O., 2000, Massive dissociation of gas hydrate during a Jurassic oceanic anoxic event: Nature, v. 406, p. 392-395, doi:10.1038/35019044.

Hild, E., and Brumsack, H.J., 1998, Major and minor element geochemistry of lower Aptian sediments from the NW German Basin (core Hoheneggelsen KB 40): Cretaceous Research, v. 19, p. 615-633, doi:10.1006/ cres.1998.0122.

Hinnov, L.A., and Ogg, J.G., 2007, Cyclostratigraphy and the astronomical time scale: Stratigraphy, v. 4, p. 239-251.

Hochuli, P.A., Menegatti, A.P., Weissert, H., Riva, A., Erba, E., and Premoli Silva, I., 1999, Episodes of high productivity and cooling in the early Aptian Alpine Tethys: Geology, v. 27, p. 657-660, doi:10.1130/0091 -7613(1999)027<0657:EOHPAC >2.3.CO;2.

Hoernle, K., Hauff, F., van den Bogaard, P., Werner, R., Mortimer, N., Geldmacher, J., Garbe-Schönberg, D., and Davy, B., 2010, Age and geochemistry of volcanic rocks from the Hikurangi and Manihiki oceanic Plateaus: Geochimica et Cosmochimica Acta, v. 74, p. 7196-7219, doi:10.1016/j .gca.2010.09.030

Hong, S.K., and Lee, Y.I., 2012, Evaluation of atmospheric carbon dioxide concentrations during the Cretaceous: Earth and Planetary Science Letters, v. 327, p. 23-28, doi:10.1016/j.eps1.2012.01.014.

Hönish, B., Ridgwell, A., Schmidt, D.N., Thomas, E., Gibbs, S.J., Sluijs, A., Zeebe, R., Kump, L., Martindale, R.C., Greene, S.E., Kiessling, W., Ries, J., Zachos, J.C., Royer, D.L., Barker, S., Marchitto, T.M., Jr., Moyer, R., Pelejero, C., Ziveri, P., Foster, G.L., and Williams, B., 2012, The geological record of ocean acidification: Science, v. 335, no. 6072, p. 1058-1063, doi:10.1126/science.1208277.

Hu, X., Wagreich, M., and Yilmaz, I.O., 2012a, Marine rapid environmental/ climatic change in the Cretaceous greenhouse world: Cretaceous Research, v. 38, p. 1-6, doi:10.1016/j.cretres.2012.04.012.

Hu, X., Kuidong, Z., Yilmaz, I.O., and Yongxiang, L., 2012b, Stratigraphic transition and palaeoenvironmental changes from the Aptian oceanic anoxic event 1a (OAE1a) to the oceanic red bed 1 (ORB1) in the Yenicesihlar section, central Turkey: Cretaceous Research, v. 38, p. 40-51, doi:10.1016/j cretres.2012.01.007.

Huang, C., Hinnov, L., Fischer, A.G., Grippo, A., and Herbert, T., 2010, Astronomical tuning of the Aptian Stage from Italian reference sections: Geology, v. 38, p. 899-902, doi:10.1130/G31177.1.

Huber, B.T., and Leckie, R.M., 2011, Planktic foraminiferal species turnover across deep-sea Aptian/Albian boundary sections: Journal of Foraminiferal Research, v. 41, p. 53-95, doi:10.2113/gsjfr.41.1.53 
Huck, S., Rameil, N., Korbar, T., Heimhofer, U., Wieczorek, T.D., and Immenhauser, A., 2010, Latitudinally different responses of Tethyan shoal-water carbonate systems to the Early Aptian oceanic anoxic event (OAE 1a): Sedimentology, v. 57, p. 1585-1614, doi:10.1111/j.1365-3091.2010.01157.x.

Huck, S., Heimhofer, U., and Immenhauser, A., 2012, Early Aptian algal bloom in a neritic proto-North Atlantic setting: Harbinger of global change related to OAE 1a?: Geological Society of America Bulletin, v. 124, p. 1810-1825, doi:10.1130/B30587.1.

Husinec, A., Harman, C.A., Regan, S.P., Mosher, D.A., Sweeney, R.J., and Read, J.F., 2012, Sequence development influenced by intermittent cooling events in the Cretaceous Aptian greenhouse, Adriatic platform, Croatia: American Association of Petroleum Geologists Bulletin, v. 96, p. 2215-2244, doi:10.1306/05161211175.

Immenhauser, A., Hillgärtner, H., Sattler, U., Bertotti, G., Schoepfer, P., Homewood, P., Vahrenkamp, V., Steuber, T., Masse, J.P., Droste, H., Taal-van Koppen, J., van der Kooij, B., van Bentum, E., Verwer, K., Hoogerduijn Strating, E., Swinkels, W., Peters, J., Immenhauser-Potthast, I., and Al Maskery, S., 2004, Barremian-lower Aptian Qishn Formation, HaushiHuqf area, Oman: A new outcrop analogue for the Kharaib/Shu'aiba reservoirs: GeoArabia, v. 9, p. 153-194.

Immenhauser, A., Hillgartner, H., and Van Bentum, E., 2005, Microbialforaminiferal episodes in the Early Aptian of the southern Tethyan margin: Ecological significance and possible relation to oceanic anoxic event 1a: Sedimentology, v. 52, p. 77-99, doi:10.1111/j.1365-3091.2004.00683.x.

Ingram, B.L., Coccioni, R., Montanari, A., and Richter, F.M., 1994, Strontium isotopic composition of mid-Cretaceous seawater: Science, v. 264, p. 546-550, doi:10.1126/science.264.5158.546.

Ivanov, M., and Idakieva, V., 2013, Lower Aptian ammonite biostratigraphy and potential for further studies of OAE 1a in Bulgaria: Cretaceous Research, v. 39, p. 47-69, doi:10.1016/j.cretres.2012.05.013.

Jahren, A.H., Arens, N.C., Sarmiento, G., Guerrero, J., and Amundson, R., 2001, Terrestrial record of methane hydrate dissociation in the Early Cretaceous: Geology, v. 29, p. 159-162, doi:10.1130/0091-7613(2001) 029<0159:TROMHD>2.0.CO;2.

Jenkyns, H.C., 1995, Carbon-isotope stratigraphy and paleoceanographic significance of the lower Cretaceous shallow-water carbonates of Resolution Guyot, Mid-Pacific Mountains, in Winterer, E.L., Sager, W.W., Firth, J.V., and Sinton, J.M., eds., Proceedings of the Ocean Drilling Program, Scientific Results, Volume 143: College Station, Texas, Ocean Drilling Program, p. 99-104, doi:10.2973/odp.proc.sr.143.213.1995.

Jenkyns, H.C., 2003, Evidence for rapid climate change in the MesozoicPalaeogene greenhouse world: Royal Society of London Philosophical Transactions, ser. A, v. 361, p. 1885-1916, doi:10.1098/rsta.2003.1240.

Jenkyns, H.C., 2010, Geochemistry of oceanic anoxic events: Geochemistry, Geophysics, Geosystems, v. 11, Q03004, doi:10.1029/2009GC002788.

Jenkyns, H.C., and Wilson, P.A., 1999, Stratigraphy, paleoceanography, and evolution of Cretaceous Pacific guyots: Relics from a greenhouse Earth: American Journal of Science, v. 299, p. 341-392, doi:10.2475/ ajs.299.5.341.

Jenkyns, H.C., Paull, C.K., Cummins, D.I., and Fullagar, P.D., 1995, Strontium-isotope stratigraphy of lower Cretaceous atoll carbonates in the Mid-Pacific Mountains, in Winterer, E.L., Sager, W.W., Firth, J.V., and Sinton, J.M., eds., Proceedings of the Ocean Drilling Program, Scientific Results, Volume 143: College Station, Texas, Ocean Drilling Program, p. 89-97, doi:10.2973/odp.proc.sr.143.212.1995.

Jenkyns, H.C., Schouten-Huibers, L., Schouten, S., and Sinninghe Damsté, J.S., 2012, Warm Middle Jurassic-Early Cretaceous high-latitude seasurface temperatures from the Southern Ocean: Climate of the Past, v. 8, p. 215-226, doi:10.5194/cp-8-215-2012.

Jones, C.E., and Jenkyns, H.C., 2001, Seawater strontium isotopes, oceanic anoxic events, and seafloor hydrothermal activity in the Jurassic and Cretaceous: American Journal of Science, v. 301, p. 112-149, doi:10.2475/ ajs.301.2.112.

Jones, C.E., Jenkyns, H.C., Coe, A.L., and Hesselbo, S.P., 1994, Strontium isotopic variations in Jurassic and Cretaceous seawater: Geochimica et Cosmochimica Acta, v. 58, p. 3061-3074, doi:10.1016/0016-7037(94)90179-1.

Kashiyama, Y., Ogawa, N.O., Kuroda, J., Shiro, M., Nomoto, S., Tada, R., Kitazato, H., and Ohkouchi, N., 2008, Diazotrophic cyanobacteria as the major photoautotrophs during mid-Cretaceous oceanic anoxic events: Nitrogen and carbon isotopic evidence from sedimentary porphyrin: Organic Geochemistry, v. 39, p. 532-549, doi:10.1016/j .orggeochem.2007.11.010.
Keller, C.E., Hochuli, P.A., Weissert, H., Bernasconi, S.M., Giorgioni, M., and Garcia, T.I., 2011, A volcanically induced climate warming and floral change preceded the onset of OAE1a (Early Cretaceous): Palaeogeography, Palaeoclimatology, Palaeoecology, v. 305, p. 43-49, doi:10.1016/j .palaeo.2011.02.011.

Kemper, E., 1987, Das Klima der Kreide-Zeit: Geologisches Jahrbuch A, v. 96, p. $5-185$.

Kemper, E., and Zimmerle, W., 1978, Die anoxischen Sedimente der präoberaptischen Unterkreide NW-Deutschlands und ihr paläogeographischer Rahmen: Geologisches Jahrbuch A, v. 45, p. 3-41.

Kuhnt, W., Holbourn, A., and Moullade, M., 2011, Transient global cooling at the onset of early Aptian oceanic anoxic event (OAE) 1a: Geology, v. 39, p. 323-326, doi:10.1130/G31554.1.

Kuroda, J., Tanimizu, M., Hori, R.S., Suzuki, K., Ogawa, N.O., Tejada, M.L.G., Coffin, M.F., Coccioni, R., Erba, E., and Ohkouchi, N., 2011, Lead isotopic record of Barremian-Aptian marine sediments: Implications for large igneous provinces and the Aptian climatic crisis: Earth and Planetary Science Letters, v. 307, p. 126-134, doi:10.1016/j.epsl.2011.04.021.

Kuypers, M.M.M., van Breugel, Y., Schouten, S., Erba, E., and Sinninghe Damsté, J.S., 2004, $\mathrm{N}_{2}$-fixing cyanobacteria supplied nutrient $\mathrm{N}$ for Cretaceous oceanic anoxic events: Geology, v. 32, p. 853-856, doi:10.1130/ G20458.1.

Larson, R.L., 1991a, Latest pulse of Earth Evidence for a mid-Cretaceous superplume: Geology, v. 19, p. 547-550, doi:10.1130/0091-7613(1991) 019<0547:LPOEEF>2.3.CO;2.

Larson, R.L., 1991b, Geological consequences of superplumes: Geology, v. 19, p. 963-966, doi:10.1130/0091-7613(1991)019<0963:GCOS>2.3.CO;2.

Larson, R.L., and Erba, E., 1999, Onset of the mid-Cretaceous greenhouse in the Barremian-Aptian: Igneous events and the biological, sedimentary and geochemical responses: Paleoceanography, v. 14, p. 663-678, doi:10.1029/1999PA900040.

Leckie, R.M., Bralower, T.J., and Cashman, R., 2002, Oceanic anoxic events and plankton evolution: Biotic response to tectonic forcing during the midCretaceous: Paleoceanography, v. 17, 1041, doi:10.1029/2001PA000623.

Lehmann, J., Heldt, M., Bachmann, M., and Negra, M.E.H., 2009, Aptian (Lower Cretaceous) biostratigraphy and cephalopods from north central Tunisia: Cretaceous Research, v. 30, p. 895-910, doi:10.1016/j .cretres.2009.02.002.

Lehmann, J., Friedrich, O., von Bargen, D., and Hemker, T., 2012, Early Aptian bay deposits at the southern margin of the Lower Saxony Basin: Integrated stratigraphy, palaeoenvironment and OAE 1a: Acta Geologica Polonica, v. 62, p. 35-62, doi:10.2478/v10263-012-0002-2.

Leonide, P., Borgomano, J., Masse, J.P., and Doublet, S., 2012, Relation between stratigraphic architecture and multi-scale heterogeneities in carbonate platforms: The Barremian-lower Aptian of the Monts de Vaucluse, SE France: Sedimentary Geology, v. 265, p. 87-109, doi:10.1016/j .sedgeo.2012.03.019.

Li, X., Jenkyns, H.C., Zhang, C., Wang, Y., Liu, L., and Cao, K., 2014, Carbon isotope signatures of pedogenic carbonates from SE China: Rapid atmospheric $p \mathrm{CO}_{2}$ changes during middle-late Early Cretaceous time: Geological Magazine, v. 151, p. 830-849, doi:10.1017/S0016756813000897.

Li, Y., Bralower, T.J., Montañez, I.P., Osleger, D.A., Arthur, M.A., Bice, D.M., Herbert, T.D., Erba, E., and Premoli Silva, I., 2008, Toward an orbital chronology for the early Aptian Oceanic Anoxic Event (OAE1a, $\sim 120 \mathrm{Ma}$ ): Earth and Planetary Science Letters, v. 271, p. 88-100, doi:10.1016/j.epsl.2008.03.055

Lorenzen, J., Kuhnt, W., Holbourn, A., Flögel, S., Moullade, M., and Tronchetti, G., 2013, A new sediment core from the Bedoulian (Lower Aptian) stratotype at Roquefort-La Bédoule, SE France: Cretaceous Research, v. 39, p. 6-16, doi:10.1016/j.cretres.2012.03.019.

Luciani, V., Cobianchi, M., and Jenkyns, H.C., 2001, Biotic and geochemical response to anoxic events: The Aptian pelagic succession of the Gargano Promontory (southern Italy): Geological Magazine, v. 138, p. 277-298, doi:10.1017/S0016756801005301.

Luciani, V., Cobianchi, M., and Lupi, C., 2006, Regional record of a global oceanic anoxic event: OAE1a on the Apulia Platform margin, Gargano Promontory, southern Italy: Cretaceous Research, v. 27, p. 754-772, doi:10.1016/j.cretres.2006.01.003.

Mahanipour, A., Mutterlose, J., Kani, A.L., and Adabi, M.H., 2011, Palaeoecology and biostratigraphy of Early Cretaceous (Aptian) calcareous nannofossils and the $\delta^{13} \mathrm{C}_{\text {carb }}$ isotope record from NE Iran: Cretaceous Research, v. 32, p. 331-356, doi:10.1016/j.cretres.2011.0 
Mahoney, J., Fitton, G., and Wallace, P., 2001, ODP Leg 192: Basement drilling on the Ontong Java Plateau: JOIDES Journal, v. 27, no. 2, p. 2-6.

Mahoney, J.J., Storey, M., Duncan, R.A., Spencer, K.J., and Pringle, M., 1993, Geochemistry and age of the Ontong Java Plateau, in Pringle, M., Sager, W.W., Sliter, W.V., and Stein, S., eds., The Mesozoic Pacific: Geology, Tectonics, and Volcanism: American Geophysical Union Geophysical Monograph 77, p. 233-261, doi:10.1029/GM077p0233.

Malinverno, A., Erba, E., and Herbert, T.D., 2010, Orbital tuning as an inverse problem: Chronology of the early Aptian oceanic anoxic event 1a (Selli Level) in the Cismon APTICORE: Paleoceanography, v. 25, PA2203, doi:10.1029/2009PA001769.

Malinverno, A., Hildebrandt, J., Tominaga, M., and Channell, J.E.T., 2012, M-sequence geomagnetic polarity time scale (MHTC12) that steadies global spreading rates and incorporates astrochronology constraints: Journal of Geophysical Research, v. 117, B06104, doi:10.1029/2012JB009260.

Malkoč, M., Mutterlose, J., and Pauly, S., 2010, Timing of the early Aptian $\delta^{13} \mathrm{C}$ excursion in the Boreal Realm: Newsletter on Stratigraphy, v. 43, p. 251-273, doi:10.1127/0078-0421/2010/0043-0251.

Masse, J.P., and Fenerci-Masse, M., 2011, Drowning discontinuities and stratigraphic correlation in platform carbonates. The late Barremian-early Aptian record of southeast France: Cretaceous Research, v. 32, p. 659684, doi:10.1016/j.cretres.2011.04.003.

Maurer, F., van Buchem, F.S.P., Eberli, G.P., Pierson, B.J., Raven, M.J., Larsen, P., Al-Husseini, M.I., and Vincent, B., 2012, Late Aptian long-lived glacio-eustatic lowstand recorded on the Arabian Plate: Terra Nova, v. 25, p. 87-94, doi:10.1111/ter.12009.

McAnena, A., Flögel, S., Hofmann, P., Herrle, J.O., Griesand, A., Pross, J., Talbot, H.M., Rethemeyer, J., Wallmann, K., and Wagner, T., 2013, Atlantic cooling associated with a marine biotic crisis during the mid-Cretaceous period: Nature Geoscience, v. 6, p. 558-561, doi:10.1038/ngeo1850.

McArthur, J.M., 1994, Recent trends in strontium isotope stratigraphy: Terra Nova, v. 6, p. 331-358, doi:10.1111/j.1365-3121.1994.tb00507.x.

Méhay, S., Keller, C.E., Bernasconi, S.M., Weissert, H., Erba, E., Bottini, C., and Hochuli, P.A., 2009, A volcanic $\mathrm{CO}_{2}$ pulse triggered the Cretaceous Oceanic Anoxic Event 1a and a biocalcification crisis: Geology, v. 37, p. 819-822, doi:10.1130/G30100A.1.

Menegatti, A.P., Weissert, H., Brown, R.S., Tyson, R.V., Farrimond, P., Strasser, A., and Caron, M., 1998, High-resolution $\delta^{13} \mathrm{C}$ stratigraphy through the early Aptian "Livello Selli" of the Alpine Tethys: Paleoceanography, v. 13 , p. 530-545, doi:10.1029/98PA01793.

Meyers, S.R., and Sageman, B.B., 2007, Quantification of deep-time orbital forcing by average spectral misfit: American Journal of Science, v. 307 , p. 773-792, doi:10.2475/05.2007.01.

Michalik, J., Sotak, J., Lintnerova, O., Halasova, E., Bak, M., Skupien, P., and Boorova, D., 2008, The stratigraphic and paleoenvironmental setting of Aptian OAE black shale deposits in the Pieniny Klippen Belt, Slovak Western Carpathians: Cretaceous Research, v. 29, p. 871-892, doi:10.1016/j.cretres.2008.05.005.

Millán, M.I., Weissert, H.J., Fernández-Mendiola, P.A., and García-Mondéjar, J., 2009, Impact of early Aptian carbon cycle perturbations on evolution of a marine shelf system in the Basque-Cantabrian Basin (Aralar, N Spain): Earth and Planetary Science Letters, v. 287, p. 392-401, doi:10.1016/j .eps1.2009.08.023.

Millán, M.I., Weissert, H.J., Owen, H., Fernández-Mendiola, P.A., and GarcíaMondéjar, J., 2011, The Madotz Urgonian platform (Aralar, northern Spain): Paleoecological changes in response to Early Aptian global environmental events: Palaeogeography, Palaeoclimatology, Palaeoecology, v. 312, p. 167-180, doi:10.1016/j.palaeo.2011.10.005.

Moreno-Bedmar, J.A., Company, M., Bover-Arnal, T., Salas, R., Delanoy, G., Martinez, R., and Grauges, A., 2009, Biostratigraphic characterization by means of ammonoids of the lower Aptian Oceanic Anoxic Event (OAE 1a) in the eastern Iberian chain (Maestrat Basin, eastern Spain): Cretaceous Research, v. 30, p. 864-872, doi:10.1016/j.cretres.2009.02.004.

Moreno-Bedmar, J.A., Company, M., Sandoval, J., Tavera, J.M., Bover-Arnal, T., Salas, R., Delanoy, G., Maurrasse, F.J.-M.R., and Martínez, R., 2012, Lower Aptian ammonite and carbon isotope stratigraphy in the eastern Prebetic Domain (Betic Cordillera, southeastern Spain): Geologica Acta, v. 10, p. 333-350, doi:10.1344/105.000001752.

Motchurova-Dekova, N., Radulovic, V., Graziano, R., and Taddei, E.R., 2009, Orbirhynchia nadiae, a new rhynchonellide brachiopod species from the Lower Aptian of the Gargano Promontory (southern Italy): Shell structure, stratigraphy, palaeoecology and taphonomy: Neues Jahrbuch für Geologie und Palaontologie Abhandlungen, v. 252, p. 289-313, doi:10.1127/0077-7749/2009/0252-0289.

Moullade, M., Kuhnt, W., Berger, J.A., Masse, J., and Tronchetti, G., 1998, Correlation of biostratigraphic and stable isotope events in the Aptian historical stratotype of La Bedoule (southern France): Paris, Academie des Sciences Comptes Rendus, ser. II, v. 327, p. 693-698.

Mutterlose, J., 1992, Biostratigraphy and palaeobiogeography of Early Cretaceous calcareous nannofossils: Cretaceous Research, v. 13, p. 167-189, doi:10.1016/0195-6671(92)90034-N

Mutterlose, J., and Böckel, B., 1998, The Barremian-Aptian interval in NW Germany: A review: Cretaceous Research, v. 19, p. 539-568, doi:10.1006/ cres.1998.0119.

Mutterlose, J., and Bottini, C., 2013, Early Cretaceous chalks from the North Sea giving evidence for global change: Nature Communications, v. 4, p. 1-6, doi:10.1038/ncomms2698.

Mutterlose, J., Pauly, S., and Steuber, T., 2009, Temperature controlled deposition of Early Cretaceous (Barremian-early Aptian) black shales in an epicontinental sea: Palaeogeography, Palaeoclimatology, Palaeoecology, v. 273, p. 330-345, doi:10.1016/j.palaeo.2008.04.026.

Mutterlose, J., Malkoč, M., Schouten, S., Sinninghe Damsté, J.S., and Forster, A., 2010, TEX86 and stable $\delta^{18} \mathrm{O}$ paleothermometry of early Cretaceous sediments: Implications for belemnite ecology and paleotemperature proxy application: Earth and Planetary Science Letters, v. 298, p. 286298, doi:10.1016/j.eps1.2010.07.043.

Najarro, M., Rosales, I., and Martin-Chivelet, J., 2011a, Major palaeoenvironmental perturbation in an early Aptian carbonate platform: Prelude of the Oceanic Anoxic Event 1a?: Sedimentary Geology, v. 235, p. 50-71, doi:10.1016/j.sedgeo.2010.03.011.

Najarro, M., Rosales, I., Moreno-Bedmar, J.A., de Gea, G.A., Barrón, E. Company, M., and Delanoy, G., 2011b, High-resolution chemo- and biostratigraphic records of the early Aptian oceanic anoxic event in Cantabria (N Spain): Palaeoceanographic and palaeoclimatic implications: Palaeogeography, Palaeoclimatology, Palaeoecology, v. 299, p. 137-158, doi:10.1016/j.palaeo.2010.10.042

Neal, C.R., Coffin, M.F., Arndt, N.T., Duncan, R.A., Eldholm, O., Erba, E., Farnetani, C., Fitton, J.G., Ingle, S.P., Ohkouchi, N., Rampino, M.R., Reichow, M.K., Self, S., and Tatsumi, Y., 2008, Investigating large igneous province formation and associated paleoenvironmental events: A white paper for scientific drilling: Scientific Drilling, no. 6, p. 4-18, doi:10.2204/iodp.sd.6.01.2008.

Oosting, A.M., Leereveld, H., Dickens, G.R., Henderson, R.A., and Brinkhuis, H., 2006, Correlation of Barremian-Aptian (mid-Cretaceous) dinoflagellate cyst assemblages between the Tethyan and Austral realms: Cretaceous Research, v. 27, p. 792-813, doi:10.1016/j.cretres.2006.03.012.

Pancost, R.D., Crawford, N., Magness, S., Turner, A., Jenkyns, H.C., and Maxwell, J.R., 2004, Further evidence for the development of photic-zone euxinic conditions during Mesozoic oceanic anoxic events: Geological Society of London Journal, v. 161, p. 353-364, doi:10.1144/0016764903-059.

Patruno, S., Kaminski, M.A., and Coccioni, R., 2011, Agglutinated foraminifera from the proposed GSSP stratotype for the Barremian/Aptian boundary (Gorgo a Cerbara, Umbria-Marche basin, Italy): Proceedings of the Eighth International Workshop on Agglutinated Foraminifera Book Series: Grzybowski Foundation Special Publication, v. 16, p. 191-214.

Pauly, S., Mutterlose, J., and Wray, D.S., 2013, Palaeoceanography of lower Cretaceous (Barremian-Lower Aptian) black shales from northwest Germany evidenced by calcareous nannofossils and geochemistry: Cretaceous Research, v. 42, p. 28-43, doi:10.1016/j.cretres.2013.01.001.

Peropadre, D., Liesa, C.L., and Meléndez, N., 2013, High-frequency, moderate to high-amplitude sea-level oscillations during the late Early Aptian: Insights into the Mid-Aptian event (Galve sub-basin, Spain): Sedimentary Geology, v. 294, p. 233-250, doi:10.1016/j.sedgeo.2013.05.019.

Petrizzo, M.R., Huber, B.T., Gale, A.S., Barchetta, A., and Jenkyns, H.C., 2012 , Abrupt planktic foraminiferal turnover across the Niveau Kilian at $\mathrm{Col}$ de Pré-Guittard (Vocontian Basin, southeast France): New criteria for defining the Aptian/Albian boundary: Newsletters on Stratigraphy, v. 45, p. 55-74, doi:10.1127/0078-0421/2012/0013.

Premoli Silva, I., Erba, E., and Tornaghi, M.E., 1989a, Paleoenvironmental signals and changes in surface fertility in mid Cretaceous Corg-rich pelagic facies of the Fucoid Marls (central Italy): Geobios, v. 22, p. 225-236, doi:10.1016/S0016-6995(89)80059-2.

Premoli Silva, I., Ripepe, M., and Tornaghi, M.E., 1989b, Planktonic foraminiferal distribution record productivity cycles: Evidence from t 
Aptian-Albian Piobbico core (central Italy): Terra Nova, v. 1, p. 443-448, doi:10.1111/j.1365-3121.1989.tb00407.x.

Premoli Silva, I., Erba, E., Salvini, G., Verga, D., and Locatelli, C., 1999, Biotic changes in Cretaceous anoxic events: Journal of Foraminiferal Research, v. 29 , p. $352-370$.

Price, G.D., 1999, The evidence and implications of polar-ice during the Mesozoic: Earth-Science Reviews, v. 48, p. 183-210, doi:10.1016/S0012-8252 (99)00048-3.

Price, G.D., 2003, New constraints upon isotope variation during the Early Cretaceous (Barremian-Cenomanian) from the Pacific Ocean: Geological Magazine, v. 140, p. 513-522, doi:10.1017/S0016756803008100.

Price, G.D., and Hart, M.B., 2002, Isotopic evidence for Early to midCretaceous ocean temperature variability: Marine Micropaleontology, v. 46, p. 45-58, doi:10.1016/S0377-8398(02)00043-9.

Price, G.D., Williamson, T., Henderson, R.A., and Gagan, M.K., 2012, Barremian-Cenomanian paleotemperatures for Australian seas based on new oxygen-isotope data from belemnite rostra: Palaeogeography Palaeoclimatology Palaeoecology, v. 358-360, p. 27-39, doi:10.1016/j .palaeo.2012.07.015.

Quijano, M.L., Castro, J.M., Pancost, R.D., de Gea, G.A., Najarro, M., Aguado, R., Rosales, I., and Martín-Chivelet, J., 2012, Organic geochemistry, stable isotopes, and facies analysis of the Early Aptian OAE - New records from Spain (Western Tethys): Palaeogeography, Palaeoclimatology, Palaeoecology, v. 365-366, p. 276-293, doi:10.1016/j.palaeo.2012.09.033.

Rameil, N., Immenhauser, A., Warrlich, G.M.D., Hillgärtner, H., and Droste, H.J., 2010, Morphological patterns of Aptian Lithocodium-Bacinella geobodies: Relation to environment and scale: Sedimentology, v. 57, p. 883-911, doi:10.1111/j.1365-3091.2009.01124.x.

Retallack, G.J., 2001, A 300-million-year record of atmospheric carbon dioxide from fossil plant cuticles: Nature, v. 411, p. 287-290, doi:10.1038/35077041.

Robinson, S.A., Clarke, L.J., Nederbragt, A., and Wood, I.J., 2008, Mid-Cretaceous oceanic anoxic events in the Pacific Ocean revealed by carbon-isotope stratigraphy of the Calera Limestone, California USA: Geological Society of America Bulletin, v. 120, p. 1416-1426, doi:10.1130/B26350.1.

Rubin, K., 1997, Degassing of metals and metalloids from erupting seamount and mid-ocean ridge volcanoes: Observations and predictions: Geochimica et Cosmochimica Acta, v. 61, p. 3525-3542, doi:10.1016/S0016 -7037(97)00179-8.

Rückheim, S., Bornemann, A., and Mutterlose, J., 2006a, Planktic foraminifera from the mid-Cretaceous (Barremian-early Albian) of the North Sea Basin: Palaeoecological and palaeoceanographic implications: Marine Micropaleontology, v. 58, p. 83-102, doi:10.1016/j.marmicro .2005 .10 .002 .

Rückheim, S., Bornemann, A., and Mutterlose, J., 2006b, Integrated stratigraphy of an Early Cretaceous (Barremian-early Albian) North Sea borehole (BGS 81/40): Cretaceous Research, v. 27, p. 447-463, doi:10.1016/j .cretres.2005.07.005.

Saunders, A.D., 2005, Large igneous provinces: Origin and environmental consequences: Elements, v. 1, p. 259-263.

Schlager, W., 1981, The paradox of drowned reefs and carbonate platforms: Geological Society of America Bulletin, v. 92, p. 197-211, doi:10.1130/0016 -7606(1981)92<197:TPODRA > 2.0.CO;2.

Schouten, S., Hopmans, S., Forster, A., van Breugel, Y., Kuypers, M.M.M., and Sinninghe Damsté, J.S., 2003, Extremely high sea-surface temperatures at low latitudes during the middle Cretaceous as revealed by archaeal membrane lipids: Geology, v. 31, p. 1069-1072, doi:10.1130/G19876.1.

Sinton, C.W., and Duncan, R.A., 1997, Potential links between ocean plateau volcanism and global ocean anoxia at the Cenomanian-Turonian boundary: Economic Geology and the Bulletin of the Society of Economic Geologists, v. 92, p. 836-842, doi:10.2113/gsecongeo.92.7-8.836.

Skelton, P.W., and Gili, E., 2012, Rudists and carbonate platforms in the Aptian: A case study on biotic interactions with ocean chemistry and climate: Sedimentology, v. 59, p. 81-117, doi:10.1111/j.1365-3091.2011.01292.x.

Sliter, W.V., 1989, Aptian anoxia in the Pacific basin: Geology, v. 17, p. 909912, doi:10.1130/0091-7613(1989)017<0909:AAITPB>2.3.CO;2.

Stein, M., Föllmi, K.B., Westermann, S., Godet, A., Adatte, T., Matera, V., Fleitmann, D., and Berner, Z., 2011, Progressive palaeoenvironmental change during the late Barremian-early Aptian as prelude to Oceanic Anoxic Event 1a: Evidence from the Gorgo a Cerbara section (Umbria-Marche basin, central Italy): Palaeogeography, Palaeoclimatology, Palaeoecology, v. 302, p. 396-406, doi:10.1016/j.palaeo.2011.01.025.
Stein, M., Westermann, S., Adatte, T., Matera, V., Fleitmann, D., Spangenberg, J.E., and Föllmi, K.B., 2012, Late Barremian-early Aptian palaeoenvironmental change: the Cassis-La Bédoule section, southeast France: Cretaceous Research, v. 37, p. 209-222, doi:10.1016/j.cretres.2012.03.021.

Steuber, T., 2002, Plate tectonic control on the evolution of Cretaceous platformcarbonate production: Geology, v. 30, p. 259-262, doi:10.1130/0091-7613 (2002)030<0259:PTCOTE >2.0.CO;2.

Strasser, A., Caron, M., and Gjermeni, M., 2001, The Aptian, Albian and Cenomanian of Roter Sattel, Romandes Prealps, Switzerland: A highresolution record of oceanographic changes: Cretaceous Research, v. 22, p. 173-199, doi:10.1006/cres.2001.0248.

Takashima, R., Kawabe, F., Nishi, H., Moriya, K., Wani, R., and Ando, H., 2004, Geology and stratigraphy of forearc basin sediments in Hokkaido, Japan: Cretaceous environmental events on the north-west Pacific margin: Cretaceous Research, v. 25, p. 365-390, doi:10.1016/j.cretres.2004.02.004.

Tarduno, J.A., Sliter, W.V., Bralower, T.J., McWilliams, M., Premoli Silva, I., and Ogg, J.G., 1989, M-sequence reversals recorded in DSDP sediment cores from the western Mid-Pacific Mountains and Magellan Rise: Geological Society of America Bulletin, v. 101, p. 1306-1316, doi:10.1130/0016-7606(1989)101<1306:MSRRID>2.3.CO;2.

Taylor, B., 2006, The single largest oceanic plateau: Ontong Java-ManihikiHikurangi: Earth and Planetary Science Letters, v. 241, p. 372-380, doi:10.1016/j.eps1.2005.11.049.

Tejada, M.L.G., Mahoney, J.J., Duncan, R.A., and Hawkins, M.P., 1996, Age and geochemistry of basement and alkalic rocks of Malaita and Santa Isabel, Solomon Islands, southern margin of the Ontong Java Plateau: Journal of Petrology, v. 37, p. 361-394, doi:10.1093/petrology/37.2.361.

Tejada, M.L.G., Mahoney, J.J., Neal, C.R., Duncan, R.A., and Petterson, M.G., 2002, Basement geochemistry and geochronology of Central Malaita, Solomon Islands, with implications for the origin and evolution of the Ontong Java Plateau: Journal of Petrology, v. 43, p. 449-484, doi:10.1093/ petrology/43.3.449.

Tejada, M.L.G., Katsuhiko, S., Kuroda, J., Coccioni, R., Mahoney, J.J., Ohkouchi, N., Sakamoto, T., and Tatsumi, Y., 2009, Ontong Java Plateau eruption as a trigger for the early Aptian oceanic anoxic event: Geology, v. 37, p. 855-858, doi:10.1130/G25763A.1.

Tejada, M.L.G., Ravizza, G., Suzuki, K., and Paquay, F.S., 2012, An extraterrestrial trigger for the Early Cretaceous massive volcanism? Evidence from the paleo-Tethys Ocean: Scientific Reports, v. 2, no. 268, p. 1-9, doi:10.1038/srep00268.

Thierstein, H.R., 1979, Paleoceanographic implications of organic carbon and carbonate distribution in Mesozoic deepsea sediments, in Talwani, M., and Ryan, W.B.F., eds., Deep Drilling Results in the Atlantic Ocean: Continental Margins and Paleoenvironment: Washington, DC, American Geophysical Union, Maurice Ewing Series, v. 3, p. 249-274.

Timm, C., Hoernle, K., Werner, R., Hauff, F., van den Bogaard, P., Michael, P., Coffin, M.F., and Koppers, A., 2011, Age and geochemistry of the oceanic Manihiki Plateau, SW Pacific: New evidence for a plume origin: Earth and Planetary Science Letters, v. 304, p. 135-146, doi:10.1016/j.epsl.2011.01.025.

Tiraboschi, D., 2009, Variazioni quantitative del nannoplancton calcareo durante il Cretacico medio: paleoecologia, paleoceanografia e produzione di carbonato in condizioni di anossia globale ed eccesso di $p \mathrm{CO}_{2}[\mathrm{Ph} . \mathrm{D}$. thesis]: Milano, Università degli Studi di Milano.

Tiraboschi, D., Erba, E., and Jenkyns, H.J., 2009, Origin of rhythmic Albian black shales (Piobbico core, central Italy) Calcareous nannofossil quantitative and statistical analyses and paleoceanographic reconstructions: Paleoceanography, v. 24, PA2222, doi:10.1029/2008PA001670.

Tominaga, M., and Sager, W.W., 2010, Revised Pacific M-anomaly geomagnetic polarity time scale: Geophysical Journal International, v. 182, p. 203-232, doi:10.1111/j.1365-246X.2010.04619.x.

Torricelli, S., 2000, Lower Cretaceous dinoflagellate cyst and acritarch stratigraphy of the Cismon APTICORE (Southern Alps, Italy): Review of Palaeobotany and Palynology, v. 108, p. 213-266, doi:10.1016/S0034 $-6667(99) 00041-X$.

Tremolada, F., and Erba, E., 2002, Morphometric analysis of the Aptian Rucinolithus terebrodentarius and Assipetra infracretacea nannoliths: Implications for taxonomy, biostratigraphy and Paleoceanography: Marine Micropaleontology, v. 44, p. 77-92, doi:10.1016/S0377-8398(01)00038-X.

Tremolada, F., Erba, E., and Bralower, T.J., 2006, Late Barremian to Early Aptian calcareous nannofossil paleoceanography and paleoecology from the Ocean Drilling Program Hole 641C (Galicia Margin): Cretaceous Research, v. 27, p. 887-897, doi:10.1016/j.cretres.2006.04.0 
Tremolada, F., Erba, E., and Bralower, T.J., 2007, A review of calcareous nannofossil changes during the early Aptian Oceanic Anoxic Event 1a and the Paleocene-Eocene Thermal Maximum: The influence of fertility, temperature, and $p \mathrm{CO}_{2}$, in Monechi, S., Coccioni, R., and Rampino, M., eds., Large Ecosystem Perturbations: Causes And Consequences: Geological Society of America Special Paper 424, p. 87-96, doi:10.1130/2007.2424(05).

Vahrenkamp, V.C., 1996, Carbon isotope stratigraphy of the upper Kharaib and Shuaiba Formations: Implications for the Early Cretaceous evolution of the Arabian Gulf region: American Association of Petroleum Geologists Bulletin, v. 80, p. 647-661, doi:10.1306/64ED8868-1724-11D7 $-8645000102 \mathrm{C} 1865 \mathrm{D}$

Vahrenkamp, V.C., 2010, Chemostratigraphy of the Lower Cretaceous Shu' aiba Formation: A $\delta^{13} \mathrm{C}$ reference profile for the Aptian Stage from the southern Neo-Tethys Ocean, in van Buchem, F.S.P., Al-Husseini, M.I., Maurer, F., and Droste, H.J., eds., Barremian-Aptian Stratigraphy and Hydrocarbon Habitat of the Eastern Arabian Plate: GeoArabia Special Publication 4, p. 107-137.

van Breugel, Y., Schouten, S., Tsikos, H., Erba, E., Price, G.D., and Sinninghe Damsté, J.S., 2007, Synchronous negative carbon isotope shifts in marine and terrestrial biomarkers at the onset of the early Aptian oceanic anoxic event 1a: Evidence for the release of ${ }^{13} \mathrm{C}$-depleted carbon into the atmosphere: Paleoceanography, v. 22, PA1210, doi:10.1029/2006PA001341.

Verga, D., and Premoli Silva, I., 2003, Early Cretaceous planktonic foraminifera from the Tethys: The large, many-chambered representatives of the genus Globigerinelloides: Cretaceous Research, v. 24, p. 661-690, doi:10.1016/j.cretres.2003.07.007.

Verga, D., and Premoli Silva, I., 2005, Early Cretaceous planktonic foraminifera from the Tethys: The upper Aptian, planispiral morphotypes with elongate chambers: Cretaceous Research, v. 26, p. 239-259, doi:10.1016/j .cretres.2005.01.004.

Vogt, P.R., 1989, Volcanogenic upwelling of anoxic, nutrient-rich water: A possible factor in Carbonate-bank/reef demise and benthic faunal extinctions: Geological Society of America Bulletin, v. 101, p. 1225-1245, doi:10.1130/0016-7606(1989)101<1225:VUOANR>2.3.CO;2.

Weiß, W., 2012, Small planktonic foraminiferal assemblages from the Boreal Aptian Hoheneggelsen KB 9 core (Hannover, northern Germany) Distribution, biostratigraphy and palaeoceanography: Neues Jahrbuch für Geologie und Palaontologie Abhandlungen, v. 266, p. 283-317, doi:10.1127/0077-7749/2012/0284.

Weissert, H., 1989, C-isotope stratigraphy, a monitor of paleoenvironmental changes: A case study from the Early Cretaceous: Surveys in Geophysics, v. 10, p. 1-61, doi:10.1007/BF01901664.

Weissert, H., and Bréhéret, J.G., 1991, A carbonate carbon-isotope record from Aptian-Albian sediments of the Vocontian Trough (SE France): Bulletin de la Société Géologique de France, v. 162, p. 1133-1140.

Weissert, H., and Erba, E., 2004, Volcanism, $\mathrm{CO}_{2}$ and palaeoclimate: A Late Jurassic-Early Cretaceous carbon and oxygen isotope record: Geological Society of London Journal, v. 161, p. 695-702, doi:10.1144/0016 -764903-087.

Weissert, H., and Lini, A., 1991, Ice Age interludes during the time of Cretaceous greenhouse climate?, in Müller, D.W., McKenzie, J.A., and Weissert, H., eds., Controversies in Modern Geology: San Diego, California, Academic Press, p. 173-191.
Weissert, H., Mckenzie, J.A., and Channell, J.E.T., 1985, Natural variations in the carbon cycle during the Early Cretaceous, in Sundquist, E.T., and Broecker, W.S., eds., The Carbon Cycle and Atmospheric $\mathrm{CO}_{2}$ : Natural Variations Archean to Present: American Geophysical Union Geophysical Monograph 32, p. 531-545, doi:10.1029/GM032p0531.

Weissert, H., Lini, A., Föllmi, K.B., and Kuhn, O., 1998, Correlation of Early Cretaceous carbon isotope stratigraphy and platform drowning events: A possible link?: Palaeogeography, Palaeoclimatology, Palaeoecology, v. 137, p. 189-203, doi:10.1016/S0031-0182(97)00109-0.

Weissert, H., Joachimski, M., and Sarnthein, M., 2008, Chemostratigraphy: Newsletters on Stratigraphy, v. 42, p. 145-179, doi:10.1127/0078 $-0421 / 2008 / 0042-0145$.

Westermann, S., Stein, M., Matera, V., Fiet, N., Fleitmann, D., Adatte, T., and Föllmi, K.B., 2013, Rapid changes in the redox conditions of the western Tethys Ocean during the early Aptian oceanic anoxic event: Geochimica et Cosmochimica Acta, v. 121, p. 467-486, doi:10.1016/j.gca.2013.07.023.

Wignall, P.B., 2001, Large igneous provinces and mass extinctions: EarthScience Reviews, v. 53, p. 1-33, doi:10.1016/S0012-8252(00)00037-4.

Wignall, P.B., 2005, The link between large igneous province eruptions and mass extinctions: Elements, v. 1, p. 293-297, doi:10.2113/ gselements.1.5.293.

Wilkinson, I.P., 2011, Ostracoda during the Early Aptian (Early Cretaceous) greenhouse period on the Isle of Wight, England: Geologists' Association Proceedings, v. 122, p. 809-815, doi:10.1016/j.pgeola.2011.09.008.

Wissler, L., Funk, H., and Weissert, H., 2003, Response of Early Cretaceous carbonate platforms to changes in atmospheric carbon dioxide levels: Palaeogeography, Palaeoclimatology, Palaeoecology, v. 200, p. 187-205, doi:10.1016/S0031-0182(03)00450-4

Wortmann, U.G., Herrle, J.O., and Weissert, H., 2004, Altered carbon cycling and coupled changes in Early Cretaceous weathering patterns: Evidence from integrated carbon isotope and sandstone records of the western Tethys: Earth and Planetary Science Letters, v. 220, p. 69-82, doi:10.1016/S0012-821X(04)00031-7.

Yamamoto, K., Ishibashi, M., Takayanagi, H., Asahara, Y., Sato, T., Nishi, H., and Iryu, Y., 2013, Early Aptian paleoenvironmental evolution of the Bab Basin at the southern Neo-Tethys margin: Response to global carboncycle perturbations across Ocean Anoxic Event 1a: Geochemistry, Geophysics, Geosystems, v. 14, p. 1104-1130, doi:10.1002/ggge.20083.

Zakharov, Y.D., Baraboshkin, E.Y., Weissert, H., Michailova, I.A., Smyshlyaeva, O.P., and Safronov, P.P., 2013, Late Barremian-early Aptian climate of the northern middle latitudes: Stable isotope evidence from bivalve and cephalopod molluscs of the Russian Platform: Cretaceous Research, v. 44, p. 183-201, doi:10.1016/j.cretres.2013.04.007.

Zerkle, A.L., Junium, C.K., Canfield, D.E., and House, C.H., 2008, Production of ${ }^{15} \mathrm{~N}$-depleted biomass during cyanobacterial $\mathrm{N}_{2}$-fixation at high Fe concentrations: Journal of Geophysical Research, v. 113, G03014, doi:10.1029/2007JG000651.

Manuscript AcCePted by the Society 26 November 2014

Manuscript Published Online 5 March 2015 